\title{
PROCESSAMENTO MÍNIMO DE ABÓBORA (Cucurbita moschata Duch.): ALTERAÇõES FISIOLÓGICAS, QUALITATIVAS E MICROBIOLÓGICAS
}

\author{
FABIANA FUMI SASAKI
}

Dissertação apresentada à Escola Superior de Agricultura "Luiz de Queiroz", Universidade de São Paulo, para obtenção de título de Mestre e Ciências, Área de Concentração: Fisiologia de Bioquímica de Plantas.

P I R A C I C A B A

Estado de São Paulo - Brasil

Maio - 2005 


\title{
PROCESSAMENTO MÍNIMO DE ABÓBORA (Cucurbita moschata Duch.): ALTERAÇÕES FISIOLÓGICAS, QUALITATIVAS E MICROBIOLÓGICAS
}

\author{
FABIANA FUMI SASAKI \\ Engenheiro Agrônomo
}

Orientador: Prof. Dr. RICARDO ALFREDO KLUGE

Dissertação apresentada à Escola Superior de Agricultura "Luiz de Queiroz", Universidade de São Paulo, para obtenção de título de Mestre e Ciências, Área de Concentração: Fisiologia de Bioquímica de Plantas.

P I R A C I C A B A

Estado de São Paulo - Brasil

Maio - 2005 
Dados Internacionais de Catalogação na Publicação (CIP) DIVISÃO DE BIBLIOTECA E DOCUMENTAÇÃO - ESALQ/USP

Sasaki, Fabiana Fumi

Processamento mínimo de abóbora (Cucurbita moschata Duch.): alterações

fisiológicas, qualitativas e microbiológicas / Fabiana Fumi Sasaki. - - Piracicaba, 2005.

145 p. : il.

Dissertação (mestrado) - - Escola Superior de Agricultura Luiz de Queiroz, 2005.

Bibliografia.

1. Abóbora 2. Armazenamento em atmosfera modificada 3. Embalagem de alimento 4. Fisiologia pós-colheita 5. Microbiologia de alimento 6. Processamento de alimento

I. Título

CDD 635.62

"Permitida a cópia total ou parcial deste documento, desde que citada a fonte - $\mathrm{O}$ autor" 
Aos meus pais: Kazunoshim Sasaki e Marta S. A. Sasaki, pelos ensinamentos, amor, dedicação, apoio e exemplos de vida.

DEDICO.

Ao meu irmão Flávio e meus avós Takeshiro, Midori (in memorian), Shohei (in memorian) e Missao, pelo grande carinho e amizade.

Ao meu namorado Thales Sandoval Cerqueira, pelo amor, imenso carinho, constante incentivo, compreensão e colaboração durante a realização deste trabalho. 
"Pensa como pensam os sábios, mas fala como falam as pessoas simples."

(Aristóteles) 


\section{AGRADECIMENTOS}

À Deus, por proteger meu caminho e possibilitar a realização de mais uma etapa de minha vida, com a realização deste trabalho.

À Comissão do Programa de Pós-Graduação em Fisiologia e Bioquímica de Plantas, pela oportunidade da realização deste curso.

À Fundação de Amparo a Pesquisa de Estado de São Paulo (FAPESP), pela concessão da bolsa de estudo (mestrado).

Ao Prof. Dr. Ricardo Alfredo Kluge, pela excelente orientação, dedicação, apoio, amizade, compreensão e principalmente pela confiança depositada em mim.

Ao Prof. Dr. Angelo Pedro Jacomino, pelos ensinamentos, consideração, amizade e principalmente por disponibilizar a infra-estrutura e equipamentos de seu laboratório.

Ao Prof. Dr. Cláudio Rosa Gallo, pelos muitos ensinamentos em microbiologia, atenção e principalmente liberação da estrutura de seu laboratório para realização das análises microbiológicas.

Ao Prof. Dr. Edwin Moisés Marcos Ortega, pela consideração, amizade e atenção, principalmente pela realização das análises estatísticas. 
Ao Prof. Marcílio de Almeida, pela consideração e por disponibilizar a infraestrutura e equipamentos de seu laboratório.

Ao Prof. Dr. Murilo de Melo, pela consideração e amizade.

À Prof ${ }^{a}$. Dr ${ }^{\mathrm{a}}$. Delia Rodriguez-Amaya, da Faculdade de Engenharia de Alimentos de UNICAMP, pela atenção e auxílio para obtenção da metodologia de análises de carotenóides.

À Prof ${ }^{a}$. Dr ${ }^{a}$. Mieko Kimura, da UNESP de São José do Rio Preto, pela grande atenção e envio da metodologia de carotenóides totais.

A todos os professores do Departamento de Ciências Biológicas pelo convívio agradável.

À Pesquisadora Científica Claire I. G. L. Sarantópoulos, do Centro de Tecnologia de Embalagem (CETEA/ITAL), pela realização as análises das embalagens.

Ao Pesquisador Científico Dr. José Maria Monteiro Sigrist, do ITAL/FRUTHOTEC, pelo carinho, amizade e consideração, principalmente por despertar meu interesse pela pesquisa.

À técnica do Laboratório de Microbiologia de Alimentos Cecília Nogueira, pela atenção e realização das análises microbiológicas.

À técnica do Laboratório de Fisiologia Pós-Colheita, Maria das Graças Ongarelli, pelo grande auxílio nas montagens dos experimentos e nas análises, além da amizade, incentivo e carinho. 
Ao técnico do Laboratório de Pós-Colheita de Frutas Hortaliças Marcos Trevisan, pelo imenso auxílio das mais diversas formas, amizade e atenção.

À técnica do Laboratório de Cultura de Tecidos Cássia R. F. Figueiredo, pelo auxílio, consideração e amizade.

Às indústrias Acuapura Ltda., Ecolab Química Ltda e Serquímico Ltda., pela atenção, disposição e principalmente por terem cedidos gentilmente amostras de sanitizantes.

Ao meu amigo de mestrado Juan Saavedra del Aguila, pela amizade, consideração e imenso auxílio tanto na montagem dos experimentos quanto nas análises.

À minha amiga Carol, que me ajudou desde que entrei no mestrado, sempre se mostrou muito atenciosa e sempre teve uma palavra amiga.

À Maria Solizète, secretária do PPG em Fisiologia e Bioquímica de Plantas, pelos inúmeros auxílios prestados.

À Linda e Raquel (Kell), pela inestimável amizade, mesmo não tendo mais muito contato, sempre torceram por mim.

Às queridas amigas Maria Luíza (Di-lúvio) e Ana Helena (Baty), pelo carinho, incentivo e auxílio.

Aos amigos Henrique, Cecília, Raquel, Rogério, Flávia, Daniela (Dani), Ilana, Lucimara, Fernando (Cajuzin), André (Caminha), Flávio (Broka), Maitê, Patrícia (Paty), Lillian, Éder, Davi, Patrícia Cia, Gregori, Renata (Bulie), Fabiana (Fexô), Luciana (Xafa), Aninha (Elliot), Palma (Lux), Denise (Porta), Ana Laura (Lixêra), 
Lieselotte (Pamonha), Patrícia (Gatsy), Juliana (Timiko), Jonhy (Kuest), Fernando (Dão) e Carlos (Acerga) pelo companherismo.

À D. Toshie e Sr. Toshiaki pela consideração e incentivo.

Ao Dr. Luiz e D. Márcia pelo grande carinho e incentivo.

À D. Clara e Sr. Antônio, pelo imenso carinho.

À Flávia, Raphael, Daniel, Raul e Renata pelo carinho e consideração.

A todos os meus tios, tias, primos e primas pelo grande carinho.

Às bibliotecárias Silvia e Eliana da Divisão de Biblioteca e Documentação da Escola Superior de Agricultura "Luiz de Queiroz" pela atenção dedicada durante a revisão desta dissertação.

A todos que de alguma maneira contribuíram para a realização deste trabalho. 


\section{SUMÁRIO}

SUMMARY ................................................................................... Xiv

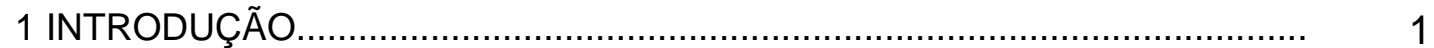

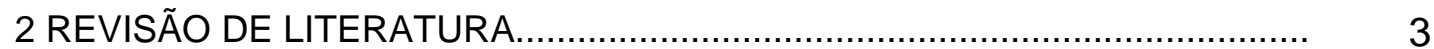

2.1 Aspectos gerais sobre a cultura de abóbora.................................. 3

2.2 Processamento mínimo............................................................... 4

2.3 Fatores que influenciam na qualidade dos produtos minimamente processados........................................................................... 5

2.3.1 Temperatura ............................................................. 5

2.3.2 Umidade Relativa.......................................................... 6

2.3.3 Respiração................................................................... 7

2.3.4 Etileno......................................................................... 8

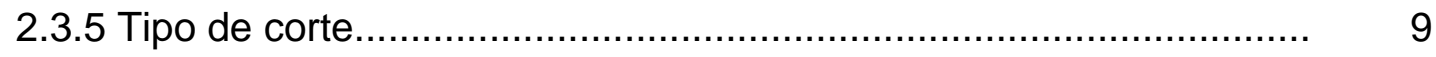

2.3.6 Atmosfera modificada..................................................... 10

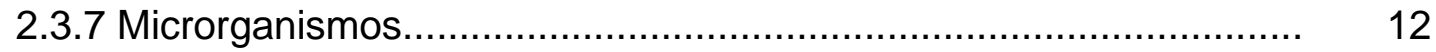

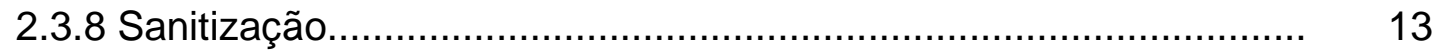

2.3.9 Carotenóides.................................................................... 14

3 ALTERAÇÕES FISIOLÓGICAS, QUALITATIVAS E MICROBIOLÓGICAS DE ABÓBORA MINIMAMENTE PROCESSADA ARMAZENADA EM DIFERENTES TEMPERATURAS ........................................................ 17

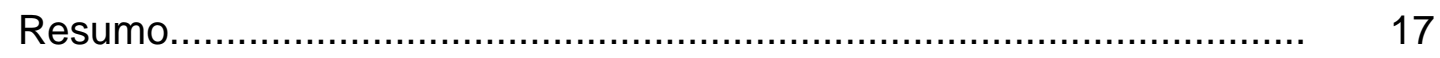

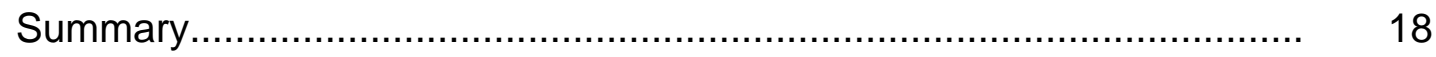

3.1 Introdução................................................................... 19 
3.2 Material e Métodos...................................................................... 20

3.3 Resultados e Discussão........................................................ 29

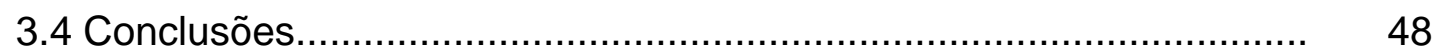

4 ALTERAÇÕES FISIOLÓGICAS, QUALITATIVAS E MICROBIOLÓGICAS NO ARMAZENAMENTO DE ABÓBORA MINIMAMENTE PROCESSADA SUBMETIDA A DIFERENTES TIPOS DE CORTE................................... 49

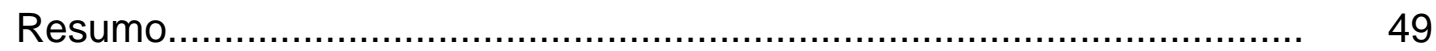

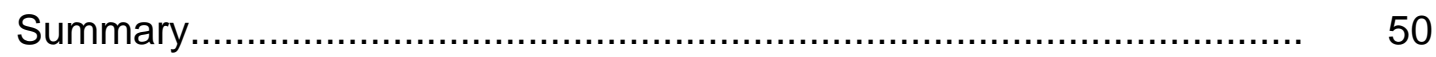

4.1 Introdução.................................................................... 50

4.2 Material e Métodos........................................................... 52

4.3 Resultados e Discussão................................................................ 55

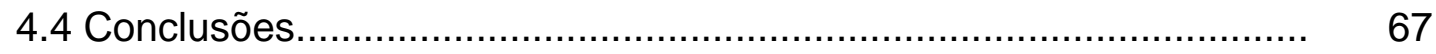

5 AVALIAÇÃO DE DIFERENTES EMBALAGENS SOBRE A QUALIDADE DA ABÓBORA MINIMAMENTE PROCESSADA............................................... 68

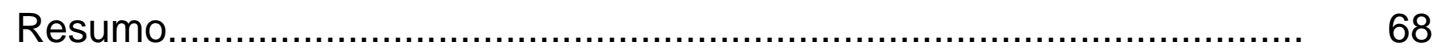

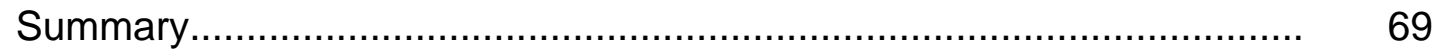

5.1 Introdução............................................................................ $\quad 70$

5.2 Material e Métodos.................................................................... 71

5.3 Resultados e Discussão............................................................. 76

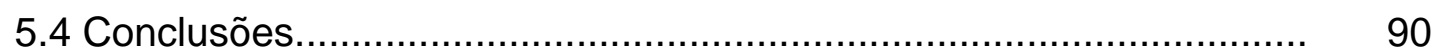

6 UTILIZAÇÃO DE DIFERENTES SANITIZANTES SOBRE A FLORA MICROBIANA DE ABÓBORA MINIMANETE PROCESSADA......................... 91

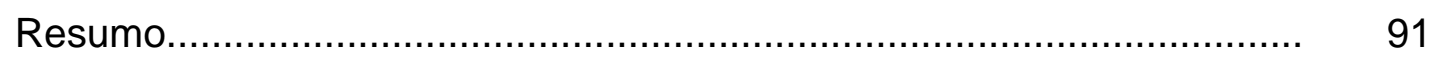

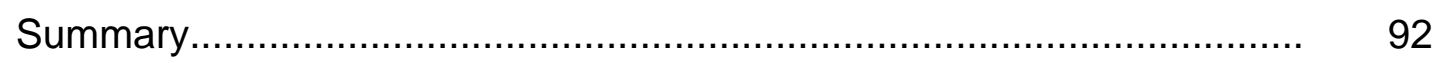

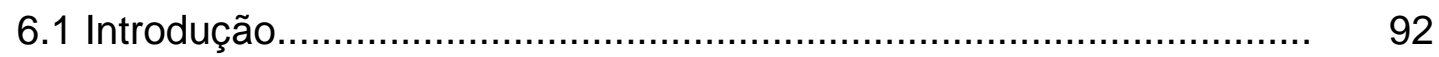

6.2 Material e Métodos................................................................... 94

6.3 Resultados e Discussão......................................................... 97

6.4 Conclusões.................................................................... 110 
7 MÉTODOS COMBINADOS PARA PROCESSAMENTO MÍNIMO DE ABÓBORA.

Resumo.

Summary.

7.1 Introdução

7.2 Material e Métodos.

7.3 Resultados e Discussão.

7.4 Conclusões 125

8 CONSIDERAÇÃO FINAL. 126

ANEXOS. 127

REFERÊNCIAS BIBLIOGRAFICAS. 131 


\title{
PROCESSAMENTO MÍNIMO DE ABÓBORA (Cucurbita moschata Duch.): ALTERAÇÕES FISIOLÓGICAS, QUALITATIVAS E MICROBIOLÓGICAS
}

\author{
Autora: FABIANA FUMI SASAKI
}

Orientador: Prof. Dr. RICARDO ALFREDO KLUGE

\section{RESUMO}

O presente trabalho teve como objetivos determinar as respostas fisiológicas, qualitativas e microbiológicas após o processamento mínimo e desenvolver um fluxograma de preparo específico para abóboras minimamente processadas, para aumentar o tempo de conservação e minimizar as perdas de qualidade. No primeiro experimento foram avaliadas diferentes temperaturas de conservação na abóbora minimamente processada, foram realizadas análises de taxa respiratória, produção de etileno, qualitativas (físicas, químicas, físicoquímicas) e microbiológicas. No segundo experimento foram estudados diferentes tipos de corte para o processamento mínimo da abóbora. Neste experimento foram efetuadas as mesmas análises realizadas no primeiro experimento. No terceiro experimento foram avaliadas as influências de diferentes embalagens na qualidade e conservação das abóboras minimamente processadas. Neste experimento foram analisadas as concentrações de gases no interior das embalagens. Também foram realizadas análises qualitativas e 
microbiológicas. O quarto experimento consistiu na avaliação da efetividade de diferentes sanitizantes sobre a microflora das abóboras minimamente processadas, foram realizadas análises microbiológicas e qualitativas. E no quinto experimento foi testado um novo fluxograma de preparo, específico para as abóboras minimamente processadas. Obtido através dos resultados dos experimentos realizados anteriormente, foram realizadas análises qualitativas $\mathrm{e}$ microbiológicas para avaliar o novo fluxograma. A temperatura de $10^{\circ} \mathrm{C}$ apresentou maior taxa respiratória, produção de etileno, perda de massa e contagem de bactérias psicrotróficas. A temperatura de $5^{\circ} \mathrm{C}$ teve um comportamento semelhante a de $1^{\circ} \mathrm{C}$. O corte em retalhos mostrou as maiores produções de etileno, perda de massa, sólidos solúveis, ácido ascórbico e carotenóides totais, e a maior contagem de bactérias psicrotróficas. O corte de meia-rodela não diferiu significativamente do corte em cubo para a maioria dos parâmetros. Das embalagens testadas nenhuma se destacou efetivamente, porém ficou clara a importância da embalagem na redução da perda de massa. Todos os sanitizantes utilizados foram efetivos na redução de bactérias psicrotróficas, na eliminação de coliformes totais e coliformes a $45^{\circ} \mathrm{C}$. O Dicloro Isocianurato de Sódio apresentou uma efetividade maior mantendo baixas contagens de bactérias psicrotróficas. $\mathrm{O}$ ácido acético e o ácido peracético provocaram perda da coloração e da firmeza dos pedaços de abóbora. Os resultados microbiológicos de todos o experimentos estavam dentro dos padrões da legislação atual. O novo fluxograma de preparo mostrou que as abóboras minimamente processadas têm um período de comercialização de 12 dias. O novo fluxograma desenvolvido é indicado para manutenção da qualidade por reduzir perdas nutricionais, diminuir a taxa respiratória e principalmente garantir a segurança alimentar do produto. 


\title{
MINIMALLY PROCESSING OF SQUASH (Cucurbita moschata Duch.): PHISIOLOGYCAL, QUALITATIVE AND MICROBIOLOGICAL CHANGES
}

Author: FABIANA FUMI SASAKI

\author{
Adviser: Prof. Dr. RICARDO ALFREDO KLUGE
}

\section{SUMMARY}

The present work was carried out with the objective of determinate the physiological, qualitative and microbiological answers after minimally processing and develop a flowchart of specific preparation to minimally processing squashes, to increase the conservation time and reduce the quality losses. Different temperatures of minimally processing squashes conservation were studied. Respiratory rate, ethylene production, qualitative (physical, chemical and physicochemical), and microbiological analyses were studied in the first experiment. In the second experiment different minimally processing squashes cut were studied. In a third experiment, different packages were study in alterations of quality and conservation of minimally processing squashes. The gas concentration inside packages was analyzed. Microbiological and qualitative analyses were carried out too. In the fourth experiment different sanitizers effect in microorganisms of minimally processing squashes were evaluated in respect to the microbiological and qualitative of product. Finally, in the fifth experiment a 
new flowchart of specific preparation to minimally processing squashes was evaluated. The flowchart was obtained with results of previous experiments. Qualitative and microbiological analyses were carried out to evaluate the new flowchart. The higher respiratory rate, ethylene production, weight loss and account of psychotropic bacteria were observed at $10^{\circ} \mathrm{C}$ temperature. The $5^{\circ} \mathrm{C}$ temperature had a similar behavior of $1^{\circ} \mathrm{C}$ temperature. The higher productions of ethylene, weight loss, soluble solids, ascorbic acid and total carotenoids, besides the higher account of psychrotrophic bacteria, were observed in shredded squash. The middle-circle cut showed a similar behavior to the cube cut in respect to the majority of the parameters evaluated. No significant differences were observed in relation to the packages studied, but its use is very important to avoid weight loss. All sanitizer studied reduced psychrotrophic bacteria, having eliminated total coliforms count and coliforms at $45^{\circ} \mathrm{C}$. Low count of psychrotrophic bacteria were observed using Sodium Isocianurate Dichlorine. Softening and color losses were observed in squashes peaces using acetic acid and peracetic acid. All experiments showed to be in actual legislation patterns in respect to the microbiological aspects. Minimally processing squashes can be stored up to 12 days under $5^{\circ} \mathrm{C}$ using the new flowchart. The new flowchart its indicated to guarantee the food safe, to reduce respiratory rate and nutritional losses, beside to keep quality of produce. 


\section{INTRODUÇÃO}

Nos últimos tempos, a sociedade vem sofrendo muitas alterações no seu estilo de vida, podendo-se notar isso pela mudança de hábitos e padrões de consumo de alimentos. Segundo Vanetti (2000), tem-se enfatizado a necessidade de uma dieta saudável ao mesmo tempo em que há uma demanda crescente de alimentos mais convenientes, frescos e com valor nutritivo, que sejam menos processados e prontos para o consumo. Nantes et al. (1999) afirmam que a falta de tempo para o preparo das refeições em casa e a crescente preocupação com a saúde e a qualidade de vida, têm sido os maiores motivadores desta situação.

O aumento da demanda por produtos minimamente processados traz consigo grandes desafios no que se refere ao desenvolvimento de tecnologias de para um maior período de conservação e armazenamento. Esses produtos apresentam maior taxa de deterioração em relação ao produto inteiro, devido a descompartimentação celular provocada pelo corte, expondo também, dessa maneira, os tecidos internos do vegetal, e acelerando o seu metabolismo. Com a exposição dos tecidos internos, estes ficam susceptíveis à contaminação microbiana, aumentando os riscos alimentares, caso não sejam tomadas medidas preventivas.

Por serem muito perecíveis, os produtos minimamente processados são comercializadas, de maneira geral, no período de, no máximo, 5 dias. 0 aumento da vida pós-colheita destes produtos para 10 a 15 dias traria grandes benefícios para o mercado, possibilitando maior expansão e flexibilidade de comercialização, além da redução de perdas. Para que isso seja alcançado, 
extensivos trabalhos de pesquisa devem ser realizados, buscando desenvolver tecnologias de armazenamento que permitam aumentar a conservação dos produtos destes produtos, minimizando a perda de qualidade.

Para prolongar a vida útil dos produtos minimamente processados, são necessários estudos referentes aos efeitos fisiológicos, qualitativos e microbiológicos causados pelo processamento mínimo. Estes estudos visam obter conhecimentos básicos importantes para a seleção e desenvolvimento de tecnologias de armazenamento os produtos.

A abóbora é uma hortaliça que tem apresentado grande potencial de expansão no mercado de vegetais minimamente processados. Abóboras são frutos de grande dimensão, com peso entre 12 e $25 \mathrm{Kg}$ por fruto, apresentando dificuldades quanto a sua comercialização, armazenamento e manuseio, ocasionando muitas perdas. Neste aspecto, o processamento mínimo poderia contribuir para um aumento na comercialização do produto, além de agregar maior valor ao mesmo. Atualmente não existem muitos estudos no país e no exterior, com relação à fisiologia e o processamento mínimo de abóboras. O fluxograma de preparo desta hortaliça minimamente processada deve ser mais bem estudado, buscando identificar pontos passíveis de manipulação, promovendo menor perda de qualidade, manutenção da segurança alimentar e aumento do tempo de conservação.

Sendo assim o presente trabalho teve como objetivos:

- Determinar as respostas fisiológicas, qualitativas e microbiológicas associadas ao processamento mínimo de abóbora. Para determinar estas respostas vários fatores foram estudados como: temperatura de armazenamento, tipos de corte e materiais de embalagens e sanitizantes.

- Desenvolver um fluxograma de preparo de abóbora minimamente processada, visando minimizar as perdas de qualidade e maximizar a capacidade de conservação do produto. 


\section{REVISÃO DE LITERATURA}

\subsection{Aspectos gerais sobre a cultura da abóbora}

Pertencente à família Cucurbitaceae e ao gênero Cucurbita, a abóbora (Cucurbita moschata Duch.) tem como centro de origem a região central do México estendendo-se até a Colômbia e a Venezuela. A aboboreira é uma planta tropical e subtropical, sendo explorada desde a antigüidade pelos povos indígenas: Astecas, Maias e Incas. Com o descobrimento da América, tornou-se cosmopolita, tal qual feijão, milho, tomate, cebola e mandioca, sendo a espécie mais importante na América Tropical, pela área em se expandiu e pela variabilidade (Casali et al, 1982; Filgueira, 2000).

A abóbora contém, em $1 \mathrm{~kg}, 1,3 \%$ de fibras e $96 \%$ de água, com a seguinte composição: 40 calorias, $280 \mathrm{mg}$ de vitamina A, 700mg de vitamina B5, $100 \mathrm{mg}$ de vitamina $B 2,55 \mathrm{mg}$ de vitamina $B$, além de sais como cálcio, fósforo, potássio, sódio, ferro e enxofre (Luengo et al, 2000). As abóboras podem ser consumidas verdes ou maduras: as verdes são preparadas em pratos salgados e as maduras são utilizadas, geralmente, na elaboração de doces caseiros ou

industrializados e também em diversos pratos salgados (Camargo Filho \& Mazzei, 2002).

Segundo o censo agropecuário do Instituto Brasileiro de Geografia e Estatística (IBGE), de 1995-96 havia, no Brasil, cerca de 112.398 produtores de abóboras, que cultivaram 104.305 hectares e colheram 215,9 milhões de frutos. A região do Sudeste brasileiro participou com 34\% e o estado de São Paulo com $54 \%$ da produção, cabendo $10 \%$ ao Rio de Janeiro, Minas Gerais e Espírito Santo (Camargo Filho, 2003). Em 2000, o estado de São Paulo cultivou 
6.263 hectares com abóboras, que resultou em 3.000 toneladas de produção (ANUÁRIO IEA, 2000). No período de 1995-2000, a quantidade média anual de abóboras e morangas comercializadas no ETSP-CEAGESP foi cerca de 24.400 $\mathrm{t} \mathrm{ano}^{-1}$, sendo a quantidade média de abóboras maduras e secas do tipo menina brasileira e outras comercializadas, em torno de $532 \mathrm{t}$ mês ${ }^{-1}$ (Camargo Filho \& Mazzei, 2002).

\subsection{Processamento mínimo}

As frutas e hortaliças frescas minimamente processadas são produtos in natura que se tornam prontos para o consumo ou uso no preparo de outros pratos. Elas são, geralmente, descascadas ou cortadas, se necessário, lavadas e submetidas a processos de sanitização (Nguyen \& Carlin, 1994). O processamento pode incluir ainda o controle de $\mathrm{pH}$, a adição de antioxidantes, a imersão em água clorada, ou a combinação destes ou outros tratamentos com outros métodos de conservação (Wiley, 1997). Esses produtos minimamente processados são, freqüentemente, embalados sob vácuo ou atmosfera modificada e comercializados por atacado para estabelecimentos de serviços e disponibilizados para vendas a varejo (Lilly Junior et al., 1996).

O propósito dos alimentos minimamente processados é proporcionar ao consumidor produtos frutícolas e hortícolas convenientes, parecidos com os frescos e com vida útil prolongada. Simultaneamente, esses produtos devem ser seguros do ponto de vista sanitário e manter sólida qualidade nutritiva e sensorial. As principais diferenças entre as frutas e hortaliças minimamente processadas e as frescas estão em alguns processos específicos e etapas realizadas na conservação (Wiley, 1997).

Uma das características mais marcantes de um tecido vegetal vivo é a manutenção de sua atividade respiratória, entre outras reações metabólicas. $O$ metabolismo dos vegetais minimamente processados é acelerado pelos danos mecânicos ocorridos durante o processamento e podem ser potencializados por 
fatores endógenos ao produto (maturidade fisiológica, cultivar) e exógenos (temperatura, atmosfera, manuseio e microrganismos) (Pushmann et al., 2002).

A durabilidade de um produto minimamente processado é extremamente baixa se comparada ao produto inteiro, considerando que nas superfícies do corte, as células e a membrana celular são destruídas e ocorre alteração no metabolismo celular. A injúria causada pelo corte promove aumento na produção de etileno e na taxa respiratória, favorecendo, assim, a rápida senescência (Vitti, 2003).

\subsection{Fatores que influenciam na qualidade dos produtos minimamente processados}

\subsubsection{Temperatura}

A temperatura é o fator mais importante para as perdas de qualidade dos vegetais em geral (Verlinden \& Nicolai, 2000). Temperaturas baixas reduzem o metabolismo e a taxa de respiração de frutas e hortaliças, além de retardarem outros processos fisiológicos, bioquímicos e microbiológicos, causadores de deterioração (Chitarra \& Chitarra, 1990). O controle da temperatura é o fator mais importante para minimizar os efeitos dos ferimentos causados aos tecidos dos produtos minimamente processados (Kader, 1992; Brecht, 1995).

Segundo a lei de Vant'Hoff, para vegetais inteiros, cada aumento de $10^{\circ} \mathrm{C}$ na temperatura (dentro de uma faixa biológica) há um incremento de duas a três vezes na velocidade das reações metabólicas, porém no caso de vegetais minimamente processados a velocidade das reações pode ser maior, devido ao estresse causado pelo processamento.

Muitos autores recomendam a temperaturas próximas de $0^{\circ} \mathrm{C}$ para $\mathrm{O}$ armazenamento de produtos minimamente processados, porém no Brasil temse tornado freqüente a utilização de temperaturas ao redor de $5^{\circ} \mathrm{C}$, e algumas vezes de $10^{\circ} \mathrm{C}$. (Cantwell, 2000; Sigrist, 1998; Vitti \& Kluge, 2002b). Um dos principais motivos para a utilização de temperaturas ao redor de $5^{\circ} \mathrm{C}$ é o fator 
econômico, pois no Brasil é economicamente inviável manter uma cadeia de frio próxima de $0^{\circ} \mathrm{C}$, para este tipo de produto.

Luengo \& Lana (1997) descrevem que a baixa temperatura é um requisito essencial e obrigatório para a conservação de hortaliças minimamente processadas. Daí a necessidade de pré resfriá-las imediatamente após a colheita e manter a cadeia do frio durante todo processo de preparo, manuseio e distribuição, inclusive ao nível de consumidor. Segundo Bennett (1971), o préresfriamento tem como principal objetivo a inibição da deterioração, uma vez que o abaixamento da temperatura retarda o crescimento de microrganismos, restringindo as atividades enzimáticas e respiratórias, preservando desta forma o frescor e o "flavor" do produto. Adicionalmente, retarda a perda de umidade e conseqüentemente enrugamento, além de reduzir a quantidade de energia gasta durante o armazenamento.

Para os produtos minimamente processados a cadeia de frio deve começar preferencialmente, logo após a colheita. Esta diminuição na temperatura aumenta a vida útil dos produtos, uma vez que retarda os processos fisiológicos dos mesmos (Wills et. al., 1981; Wiley, 1997).

\subsubsection{Umidade Relativa}

A umidade relativa (UR) pode ser definida como a relação existente entre a pressão de vapor de água presente no ar e a pressão de vapor de água presente num ar saturado, a uma mesma temperatura (Kluge et al., 2002). Como a maioria das frutas e hortaliças possuem entre 80 a $95 \%$ de água (em relação ao peso) e a umidade relativa dos espaços intercelulares é muito próxima de $100 \%$, a tendência é quase sempre do vapor d'água escapar destes espaços, através do processo de transpiração. Este processo ocorre justamente porque a umidade relativa do ambiente onde se encontram é freqüentemente menor que $100 \%$. E quanto maior a relação superfície/volume, maior a taxa de transpiração da fruta ou hortaliça (Hardenburg et al., 1986). Hortaliças minimamente processadas, devido ao corte, apresentam sempre maior relação 
superfície/volume do que quando inteiras, facilitando ainda mais a perda de água de seus tecidos (Tatsumi et al., 1991).

A perda de água é uma das principais causas de deterioração de frutas e hortaliças após a colheita, por produzirem o amarelecimento e o enrugamento de seus tecidos (Sigrist, 1998).

\subsubsection{Respiração}

A respiração é o principal processo fisiológico que continua ocorrendo após a colheita. A respiração consiste na decomposição oxidativa de substâncias complexas presente nas células, como amido, açúcares e ácidos orgânicos, em moléculas simples $\left(\mathrm{CO}_{2}\right.$ e $\left.\mathrm{H}_{2} \mathrm{O}\right)$, com produção de energia. Este processo é a indicação do metabolismo do produto indicando sua intensidade (Kays, 1991).

O tipo e a intensidade de atividade fisiológica pós-colheita, as quais dependem das funções naturais de cada parte da planta, determinam, em grande extensão, a longevidade do material, durante o armazenamento na etapa pós-colheita (Chitarra \& Chitarra, 1990).

A conservação de um produto está diretamente relacionada com a taxa respiratória, sendo que a perecibilidade de um produto é diretamente proporcional à sua atividade respiratória (Vitti, 2003).

O efeito do corte e outras injúrias, provocadas durante as etapas do processamento mínimo, têm como conseqüências o rompimento de organelas, modificação da permeabilidade da célula, desorganização celular, ativação da síntese de etileno e aumento na respiração (Chitarra, 1998). A taxa respiratória dos alimentos minimamente processados é aumentada de 3 a 7 vezes, em relação ao tecido intacto, o que se traduz em rápido consumo de oxigênio dentro da embalagem (Varoquaux \& Wiley, 1997). Assim, o controle da respiração passa a ser condição essencial para obtenção de condições adequadas de armazenamento dos produtos perecíveis (Chitarra \& Chitarra, 1990). 
A redução da respiração pode ser conseguida com o abaixamento da temperatura, favorecendo a diminuição nas perdas de aroma, sabor, textura, cor e demais atributos de qualidade (Chitarra \& Chitarra, 1990).

De igual forma, a atmosfera modificada e/ou controlada pode reduzir o consumo de oxigênio e a produção de $\mathrm{CO}_{2}$ (Varoquaux \& Wiley, 1997). A redução do $\mathrm{O}_{2}$ e/ou elevação do $\mathrm{CO}_{2}$ para reduzir a taxa respiratória de frutas e vegetais minimamente processados tem sido reconhecida como a principal razão dos efeitos benéficos da atmosfera modificada e/ou controlada. Porém, trata-se de simplificação, já que a deterioração pós-colheita de vegetais e frutas frescas pode ser causada por muitos fatores adicionais à taxa respiratória, que incluem: mudanças metabólicas (mudanças bioquímicas associadas com o metabolismo respiratório, biossíntese e ação do etileno e mudanças composicionais), injúrias físicas, perda de água, desordens fisiológicas e microbiológicas (Kader, 1986).

\subsubsection{Etileno}

O etileno, composto volátil de dois carbonos $\left(\mathrm{C}_{2} \mathrm{H}_{4}\right)$, é produzido endogenamente, talvez, por todas as plantas. Em concentrações tão baixas quanto $0,1 \mu \mathrm{L} \mathrm{L}^{-1}$, o etileno pode induzir uma séria de respostas fisiológicas, incluído amadurecimento, senescência e desordens fisiológicas (Watada, 1986). Este fitohormônio, encontrado nos espaços intercelulares, tem como precursor primário o aminoácido metionina, como intermediário o SAM (Sadenosilmetionina) e como precursor imediato o ACC (ácido aminociclopropano carboxílico). A enzima ACC sintase catalisa a reação de formação do ACC a partir do SAM, e a enzima ACC oxidase oxida o ACC, formando o etileno (Yang, 1985).

A síntese de etileno pode ser induzida por fatores externos como elevação da temperatura e injúrias mecânicas, promovendo sua atuação em sítios específicos nas células, usualmente ativando ou inibindo enzimas do ciclo 
metabólicos dos tecidos. O etileno contribui para biossíntese de enzimas envolvidas em alterações bioquímicas e fisiológicas (Brecht, 1995).

Devido a processos como descascamento e corte, inevitáveis no processamento mínimo, os vegetais minimamente processados comportam-se como produtos que sofreram injúrias mecânicas. Por isso a produção de etileno por frutas e hortaliças minimamente processadas pode ser incrementada em até 20 vezes, quando comparada com vegetais intactos (Varoquaux \& Wiley, 1997). O etileno produzido em decorrências das lesões, também denominado de "etileno de ferida" acelera a deterioração e a senescência dos tecidos vegetais (Brecht, 1995).

\subsubsection{Tipo de corte}

No processamento mínimo de frutas e vegetais, as etapas do processo como corte, descascamento e outras ações físicas causam injúrias e danos aos tecidos. No entanto, estas ações físicas são necessárias no preparo de produtos frescos para consumo direto (Huxsoll \& Bolin, 1989).

Os tecidos fatiados, cuja superfície de exposição é maior, apresentam maiores taxas de respiração e, conseqüentemente, maiores alterações fisiológicas, bioquímicas e microbiológicas que o tecido inteiro (Porte \& Maia, 2001).

A produção de etileno aumenta com a severidade do ferimento. O uso de facas não afiadas danifica mais o produto e a sua durabilidade é menor em comparação com o uso de facas bem afiadas (Vitti \& Kluge, 2002b).

Segundo Brecht (1995) quanto mais retalhada a alface menor sua durabilidade. Entretanto, alface rasgada preserva-se melhor que a retalhada, pois exuda menos seiva da célula. O mesmo autor afirma que tanto a intensidade dos cortes quanto à direção em que foram realizados interferiram na deterioração de pimentão verde minimamente processado, que foi mais lenta nos corte transversais quando comparado aos longitudinais. De acordo com o 
autor, tais resultados parecem estar associados à maior solubilização da pectina na superfície das fatias longitudinais.

Watada et al. (1990) observaram que o fatiamento de bananas verdes contribuiu para a intensificação de síntese de etileno, verificando a existência de uma inter-relação entre a espessura de corte e o nível de etileno sintetizado, sendo que as fatias com espessura da $2 \mathrm{~mm}$ apresentaram síntese de etileno substancialmente mais elevada que as fatias de 4 ou $6 \mathrm{~mm}$. O etileno sintetizado em resposta às injúrias acelerou o amolecimento da polpa de bananas e kiwis minimamente processados, bem como a perda de clorofila em espinafre minimamente processado (Abe \& Watada, 1991).

\subsubsection{Atmosfera modificada}

A conservação de produtos hortícolas em condições de atmosfera modificada (AM) pode ser definida como armazenamento realizado sob condições de composição da atmosfera diferente daquela presente na atmosfera do ar normal. $\mathrm{Na}$ atmosfera normal $\mathrm{O}_{2} \mathrm{O}_{2}$ está presente na concentração de $21 \%$, enquanto que $\circ \mathrm{CO}_{2}$ apresenta-se com concentrações de cerca de 0,03\% (Lana \& Finger, 2000).

O sistema com atmosfera modificada mais utilizado consiste no acondicionamento do produto hortícola em uma embalagem selada e semipermeável a gases, a fim de reduzir a concentração de $\mathrm{O}_{2}$ e aumentar a concentração de $\mathrm{CO}_{2}$ no interior da mesma. A magnitude das alterações nas condições destes gases depende da natureza e espessura do material de embalagem, da taxa respiratória do produto, da relação entre a quantidade de produto e a área superficial da material de embalagem e da temperatura de armazenamento (Lana \& Finger, 2000).

A atmosfera pode ser criada de forma passiva ou ativa. No caso da atmosfera modificada passiva, o produto é acondicionado em embalagens e a atmosfera é modificada pela própria respiração do produto. A atmosfera 
modificada ativa é criada injetando-se no espaço livre da embalagem uma mistura gasosa pré-determinada (Yam \& Lee, 1995; Hotchkiss, 1995).

Com a finalidade de se manter uma condição adequada de higiene, os vegetais minimamente processados, na maioria das vezes, são acondicionados em embalagens seladas. Através do processo respiratório estes vegetais minimamente processados tendem a modificar a atmosfera em que estão, no interior de embalagens de filmes flexíveis (Sigrist, 1998).

A modificação da atmosfera faz com que frutas e hortaliças respirem cada vez menos, diminuindo seus metabolismos. Associada a baixas temperaturas, esta técnica tem se mostrado muito eficiente em prolongar a vida pós-colheita de muitos produtos, tanto na forma inteira quanto na de minimamente processada (Kader, 1992; Chitarra, 1998). A reação de redução do metabolismo respiratório que ocorre em baixos teores de $\mathrm{O}_{2}$, pode ser resultado do decréscimo da atividade de algumas enzimas específicas, como a polifenoloxidase e a acidoglicolicoxidase ou ácido ascórbico oxidase, cujas afinidades pelo oxigênio pode ser de 5 a 6 vezes menor que a da citocromo oxidase. A atividade da enzima citocromo oxidase não é suprimida em baixos teores de oxigênio, devido à sua afinidade com o mesmo se muito alta (Weichmann, 1987).

Níveis reduzidos de $\mathrm{O}_{2}$ e elevados de $\mathrm{CO}_{2}$ também contribuem para que as frutas e hortaliças produzam menos etileno e para a redução da sensibilidade destes produtos a este gás. Conseqüentemente, retardam 0 amadurecimento e a senescência dos tecidos vegetais (Kader, 1992).

Composições atmosféricas estabilizadas em torno de $25 \%$ de $\mathrm{CO}_{2}$ e $<1 \%$ de $\mathrm{O}_{2}$ diminuíram significativamente a sobrevivência de microrganismos patógenos (Kader, 1992). Contudo concentrações muito baixas de $\mathrm{O}_{2}(1 \%)$ ou muito altas de $\mathrm{CO}_{2}(>10 \%)$ podem levar a respiração anaeróbica, que está associada a injúrias fisiológicas e cria risco de crescimento de microrganismos patogênicos anaeróbicos como o Clostridium botulinum (Vitti \& Kluge, 2002a). 


\subsubsection{Microrganismos}

As alterações microbiológicas que ocorrem em vegetais variam segundo a composição da microbiota de cada alimento, que por sua vez está relacionada com outros fatores. O ambiente, a manipulação, a água disponível, a umidade, a temperatura, a atmosfera e a acidez são os mais importantes. De maneira geral, as alterações são causadas por mesófilos, bactérias ácido lácticas, coliformes totais e fecais, bactérias pectinolíticas, leveduras e fungos (Watada et al.,1996).

A microbiota de frutos e hortaliças minimamente processados é importante, pois esses alimentos podem mudar o microambiente pela sua própria atividade metabólica (Brackett, 1997). Com o processamento mínimo, o aumento em superfície pelo corte, dano e disponibilidade de nutrientes, provêem condições que aumentam o número e os tipos de microrganismos que aí se desenvolvem. Além disso, o aumento da manipulação desses produtos possibilita a contaminação por patógenos. (Rosa \& Carvalho, 2000).

As hortaliças apresentam elevada quantidade de água e de nutrientes e $\mathrm{pH}$ neutro. Assim, as bactérias tornam-se os microrganismos preponderantes nestes alimentos, pois em $\mathrm{pH}$ neutro seu crescimento é mais rápido que o dos fungos, diferentemente das frutas que apresentam $\mathrm{pH}$ ácido e propiciam a proliferação mais rápida de fungos (Brackett, 1997).

Schlimme (1995) ressalta que, algumas das bactérias que podem estar presentes nesses produtos são patogênicas aos consumidores, incluindo Clostridium botulinum e Listeria monocytogenes, além daquelas que chegam ao produto por contaminação humana durante a manipulação como Staphylococcus aureus e Streptococcus spp. Entretanto, a maior parte dos microrganismos presentes nos vegetais frescos é saprófita, tais como: Erwinia, Aeromonas e Enterobacter; coliformes e micrococus; Pseudomonas presentes no ar, no solo e na água; como também as bactérias gram-negativas como Bacillus e bactérias corineformes (Carllister \& Agger, 1987; Schlimme,1995; Nguyen \& Carlin, 1994). 
De acordo com a Resolução RDC n 12 de 02/01/2001, da Agência Nacional de Vigilância Sanitária (ANVISA) que pertence ao Ministério da Saúde, a legislação sanitária de alimentos exige, para hortaliças in natura, a ausência da Salmonella (em $25 \mathrm{~g}$ da amostra) e admite, no máximo, $10^{2} \mathrm{NMP}$ (número mais provável) de coliformes fecais/g de produto para a preservação da saúde pública.

Hiraishi \& Horie (1982) afirmam que os coliformes são bons indicadores de contaminação fecal em alimentos. De acordo com a Internacional Commission on Microbiological Specifications for Foods - ICMSF (1978), a presença de coliformes em alimentos indica manipulação inadequada durante o processamento, uso inadequado de equipamentos em más condições sanitárias ou ainda utilização de matéria-prima contaminada.

Amostras de hortaliças minimamente processadas, desde a produção até a distribuição ao nível do consumidor, devem sofrer análises microbiológicas freqüentes. É importante também a sanitização de toda a planta de processamento, inclusive dos instrumentos e equipamentos utilizados, bem como a utilização de luvas, máscaras, aventais e botas por parte dos operadores, o uso de água clorada para a lavagem das hortaliças e um controle bastante rigoroso da temperatura (Sigrist, 1998).

\subsubsection{Sanitização}

A sanitização de frutos e hortaliças minimamente processadas desempenha importante papel na minimização da deterioração e na manutenção da qualidade do produto (Brackett, 1992), uma vez que, durante o processamento, seja, talvez a única chance de diminuir o número de microrganismos contaminantes presente. (Oliveira, 2001). Segundo Vitti \& Kluge (2002a), a sanitização realizada através de imersão é um meio efetivo para a redução da maioria dos microrganismos que tenham permanecido após a lavagem com detergente. 
A sanitização é portanto, uma etapa de relevância no processamento mínimo e o cloro, nas suas várias formas, é o sanitizante mais usado em alimentos (Dychdala, 1991).

Os tratamentos de higienização e sanitização devem ser estabelecidos em conjunto com o programa de APPCC, boas práticas de processamento agrícola e industrial, incluindo o treinamento de funcionários e estabelecimento de especificações da indústria com o objetivo de reduzir o risco microbiológico (Vanetti, 2000). A indústria de alimentos preocupa-se com a sanitização e desinfecção por, pelo menos, três razões: necessidade, qualidade e segurança. A terceira razão é, talvez, a mais importante, pois a menos que o produto seja seguro, a boa qualidade não tem sentido (Fantuzzi, 1999).

Muitos autores recomendam o uso de 50 a 200ppm de cloro ativo na solução para sanitização tanto antes do corte quanto após este processo.

\subsubsection{Carotenóides}

Os carotenóides são compostos poliênicos, lipossolúvies responsáveis pelas cores atraentes, características de muitos alimentos, que se estendem desde o a cor amarela ao roxo (Rodríguez-Amaya \& Amaya-Farfan, 1992). A variação da coloração é dada pelo cromóforo-absorvedor de luz, formado pela existência de um sistema de duplas ligações. As bandas de absorção na região dos 400 a $500 \mathrm{~nm}$ imprimem nos carotenóides sua coloração alaranjada característica. A cor das cenouras e abóboras, por exemplo, deve-se ao $\beta$ caroteno (Taiz \& Zeiger, 2002).

Os carotenóides são biossintetizados em plantas superiores, algas, fungos e bactérias. Os animais não são capazes de sintetizar carotenóides, embora sejam capazes de metabolizá-los. Como as plantas são capazes de biossintetizar os carotenóides, sua composição é enriquecida pela presença de pequenas quantidades de carotenóides ou traços dos precursores biossintéticos (Rodrígues-Amaya, 2001). 
Os carotenóides constituem integralmente as membranas dos tilacóides e estão, em geral, intimamente associadas aos pigmentos protéicos das antenas e dos centros de reação. A luz absorvida pelos carotenóides é transferida à clorofila para o processo de fotossíntese; em decorrência do papel que desempenham são chamados de pigmentos acessórios. Além da sua função como pigmento acessório, os carotenóides desempenham um papel essencial nas plantas, o da fotoproteção (Taiz \& Zeiger, 2002).

Segundo Rodrígues-Amaya (2001), carotenóides são tetraterpenóides (com 40 carbonos), formados pela polimerização de 8 unidades de isoprenos (com 5 carbonos cada). Os terpenos são sintetizados a partir da Acetil Coenzima $A$, na via do ácido mevalônico.

Quimicamente os carotenóides se dividem em dois grupos: os hidrocarbonatados e os oxigenados. Os membros do primeiro grupo são universalmente conhecidos como carotenos e os membros do segundo grupo são chamados de xantofilas.

Do ponto de vista nutricional, os carotenóides podem ser ativos ou inativos. Para que um carotenóide tenha atividade provitamínica, é necessário que possua pelo menos um anel de $\beta$-ionona não substituído com cadeia lateral poliênica de pelo menos 11 carbonos, ou seja, a molécula deve ter pelo menos a metade da molécula do $\beta$-caroteno (Blanc, 1973; Rodriguez-Amaya, 2001). Assim, o $\beta$ - caroteno (Figura 1 ) tendo dois anéis de $\beta$-ionona ligados por uma cadeia poliênica de 22 carbonos, possui a maior atividade (100\%). O $\alpha$-caroteno (no qual a ligação dupla está fora de conjugação formando um anel $\alpha$-ionona) e o $y$-caroteno (com apenas um anel de $\beta$-ionona) exibem metade da atividade provitamínica do $\beta$-caroteno (Rodriguez-Amaya, 1985). 


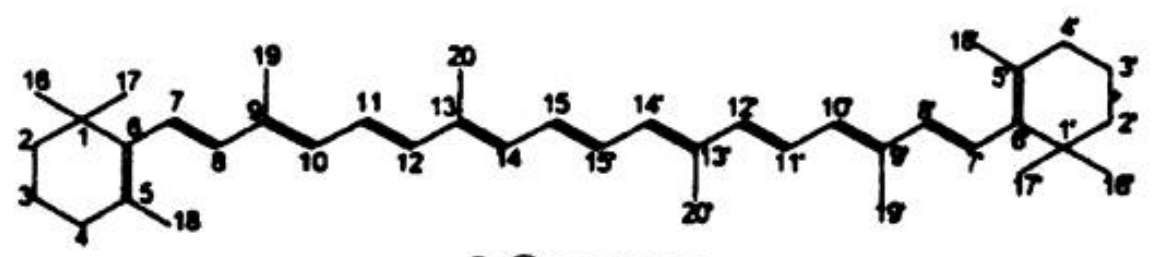

$\beta$-Carotene

Figura 1 - Fórmula do $\beta$-caroteno

Acredita-se que os carotenóides, provitamina a ou não, tem efeitos benéficos à saúde humana, aumentando as respostas imunológicas e reduzindo riscos de doenças degenerativas, tal qual o câncer, doenças cardiovasculares e catarata. A ação dos carotenóides sobre as doenças tem sido atribuída pela sua propriedade antioxidante, especificamente seqüestrando o oxigênio singleto e interagindo com os radicais livres presentes no organismo (Rodriguez-Amaya, 2002).

Segundo Rodriguez-Amaya (2002) as abóboras (Cucurbita mochata) são importante fonte de $\alpha$ caroteno e $\beta$-caroteno. Este vegetal pode ser consumido em vários estágios do desenvolvimento dos frutos, desde imaturo a completamente maduro e, quando maduros, podem ser armazenados durante meses, permitindo o seu consumo durante 0 ano inteiro Entretanto esta flexibilidade no consumo afeta a variação da composição dos carotenóides ao longo do período de armazenamento. 


\section{ALTERAÇÕES FISIOLÓGICAS, QUALITATIVAS E MICROBIOLÓGICAS DE ABÓBORA MINIMAMENTE PROCESSADA ARMAZENADA EM DIFERENTES TEMPERATURAS}

\section{Resumo}

O presente estudo teve como objetivo estudar as alterações fisiológicas, qualitativas e microbiológicas em abóboras minimamente processadas armazenadas em temperaturas de $1^{\circ} \mathrm{C}, 5^{\circ} \mathrm{C}$ e $10^{\circ} \mathrm{C}$, e $85-90 \%$ UR. A $10^{\circ} \mathrm{C}$ as abóboras apresentaram maiores taxas respiratórias $\left(34,27 \mathrm{~mL} \mathrm{CO}_{2} \mathrm{Kg}^{-1} \mathrm{~h}^{-1}\right) \mathrm{e}$ maiores taxas de produção de etileno $\left(24,49 \mu \mathrm{L}_{2} \mathrm{H}_{4} \quad \mathrm{Kg}^{-1} \mathrm{~h}^{-1}\right)$. Nesta temperatura houve aumento da perda de massa, redução dos teores de sólidos solúveis, de ácido ascórbico, de carotenóides totais e maior desenvolvimento de bactérias pscicrotróficas. A temperatura de $1^{\circ} \mathrm{C}$ apresentou menores taxas respiratórias, chegando a $9,66 \mathrm{~mL} \mathrm{CO}_{2} \mathrm{Kg}^{-1} \mathrm{~h}^{-1}$, e produção de etileno $<0,03 \mu \mathrm{L}$ $\mathrm{C}_{2} \mathrm{H}_{4} \mathrm{Kg}^{-1} \mathrm{~h}^{-1}$, além de menores perdas nos teores de sólidos solúveis, ácido ascórbico e carotenóides totais. O crescimento de bactérias pscicrotróficas a $1^{\circ} \mathrm{C}$ se apresentou, até o $12^{\circ}$ dia, dentro do limite permitido, ficando 2 ciclos logarítmicos abaixo da contagem de $10^{\circ} \mathrm{C}$. A temperatura de $5^{\circ} \mathrm{C}$ teve comportamento semelhante a $1^{\circ} \mathrm{C}$, porém seus valores para todas as análises ficaram intermediários entre os valores de $1^{\circ} \mathrm{C}$ e $10^{\circ} \mathrm{C}$, aproximando dos valores da temperatura mais baixa. Não foi detectada presença de Salmonella, e o crescimento de coliformes totais e coliformes a $45^{\circ} \mathrm{C}$ em nenhuma das temperaturas de armazenamento. 
Palavras-chave: Cucurbita moschata Duch., processamento mínimo, refrigeração, taxa respiratória, etileno, microbiologia.

\section{PHYSIOLOGICAL, QUALITATIVE AND MICROBIOLOGICAL CHANGES IN MINIMALLY PROCESSED SQUASH STORED IN DIFFERENT TEMPERATURES}

\section{Summary}

The present work was carried out with the objective of determinate the physiological, qualitative and microbiological changes in minimally processing squashes stored at $1^{\circ} \mathrm{C}, 5^{\circ} \mathrm{C}$ or $10^{\circ} \mathrm{C}$ and $85-90 \% \mathrm{RH}$. Squashes kept at $10^{\circ} \mathrm{C}$ showed higher respiratory rate $\left(34,27 \mathrm{~mL} \mathrm{CO}_{2} \mathrm{~kg}^{-1} \mathrm{~h}^{-1}\right.$ in the $3^{\text {rd }}$ day) and the higher ethylene production $\left(24,49 \mu \mathrm{L}_{2} \mathrm{H}_{4} \mathrm{~kg}^{-1} \mathrm{~h}^{-1}\right.$. In this temperature also observed higher account of psychrotrophic bacteria and loss of carotenoids, ascorbic acid and soluble solids, besides increasing of weight loss. In the temperature of $1^{\circ} \mathrm{C}$ it was observed the lower respiratory rate $\left(9,66 \mathrm{~mL} \mathrm{CO} \mathrm{CO}_{2}\right.$ $\mathrm{Kg}^{-1} \mathrm{~h}^{-1}$ in the $3^{\circ}$ day) and ethylene production $\left(\leq 0,03 \mu \mathrm{L}_{2} \mathrm{H}_{4} \mathrm{~kg}^{-1} \mathrm{~h}^{-1}\right.$ ), besides lower losses of soluble solid, ascorbic acid and carotenoids. Psychrotrophic bacteria growth in $1^{\circ} \mathrm{C}$ was presented, until $12^{\circ}$ day, inside of permitted limit, about 2 logarithmic cycles under $10^{\circ} \mathrm{C}$ count. The $5^{\circ} \mathrm{C}$ temperature had a similar behavior of $1^{\circ} \mathrm{C}$ temperature, but the values of all analyses were intermediate between $1{ }^{\circ} \mathrm{C}$ and $10^{\circ} \mathrm{C}$, approaching of lower temperature values. Salmonella, total coliforms growing and coliformes in $45^{\circ} \mathrm{C}$ did not were detected in the storage temperatures evaluated.

Key-words: Cucurbita moschata Duch., minimally processing, refrigeration, respiratory rate, ethylene, microbiology. 


\subsection{Introdução}

O processamento mínimo é definido como qualquer alteração física causada em frutos ou hortaliças que mantém o estado fresco desses produtos. Inclui as operações de seleção, lavagem, corte, sanitização, centrifugação, embalagem, armazenamento e comercialização (IFPA, 1999; Moretti, 1999).

Como em todas as frutas e vegetais, os produtos minimamente processados deterioram-se após o processamento, devido à sua própria ação fisiológica e à ação microbiana (Varoquaux, 1987). O estresse causado pelo processamento resulta em aumento da respiração e produção de etileno, aumentando a atividade de enzimas responsáveis pelo escurecimento, desenvolvimento de sabores e odores desagradáveis e amaciamento dos tecidos (Wiley, 1997; Cantwell, 1992).

O frio tem importante papel na conservação dos alimentos, já que a diminuição da temperatura retarda as transformações provocadas por reações bioquímicas e diminui disseminação de bactérias e fungos (Vissoto et al., 1999). Temperaturas baixas reduzem o metabolismo e a taxa de respiração das hortaliças, além de retardarem outros processos fisiológicos, bioquímicos e microbiológicos causadores da deterioração.

Muitos autores recomendam a temperaturas próximas de $0^{\circ} \mathrm{C}$ para $\mathrm{O}$ armazenamento de produtos minimamente processados, mas no Brasil é mais freqüente a utilização de temperaturas ao redor de $5^{\circ} \mathrm{C}$, e algumas vezes de $10^{\circ} \mathrm{C}$, devido ao fator econômico.

Segundo Wiley (1997), temperaturas superiores a $10^{\circ} \mathrm{C}$ promovem um incremento muito rápido na concentração de $\mathrm{CO}_{2}$ dentro das embalagens, devido ao aumento na atividade metabólica do produto e ao crescimento microbiano.

Vários trabalhos na literatura relatam estudos referentes ao metabolismo de diversas frutas e hortaliças minimamente processadas e armazenadas sob 
diferentes temperaturas. Entretanto, existem pouco estudos contemplando o processamento mínimo de abóboras.

Desse modo, o objetivo deste estudo é verificar as alterações fisiológicas, qualitativas e microbiológicas de abóboras minimamente processadas armazenadas sob diferentes temperaturas, visando manter a qualidade e aumentar o tempo de conservação de abóbora minimamente processada.

\subsection{Material e Métodos}

\section{Obtenção da matéria-prima}

Abóboras maduras (Cucurbita moschata Duch.) cv. Canhão, provenientes da região de Tupã-SP, foram pré-selecionadas quanto ao tamanho, cor da casca e formato (pescoço reto), além da ausência de injúrias. Após selecionadas, foram levadas ao laboratório de Pós-Colheita do Departamento de Produção Vegetal da ESALQ/USP onde sofreram uma lavagem inicial com água corrente e detergente, para retirada de sujidades grosseiras. Após a lavagem, os frutos foram imersos em solução com 200ppm de cloro ativo, para uma desinfecção inicial, os frutos permaneceram por 10 minutos. O sanitizante utilizado tem como princípio ativo o Dicloro STriazinatriona Sódica Diidratada (SUMAVEG ${ }^{\circledR}$ ). Em seguida, as abóboras foram colocadas em câmara fria a $10^{\circ} \mathrm{C}$ onde permaneceram por um período de descanso de 16 horas, para manter baixa a atividade metabólica do produto.

\section{Processamento mínimo}

Todas as etapas do processamento mínimo ocorreram dentro de uma câmara fria a temperatura de $10 \pm 1^{\circ} \mathrm{C}$ e sobre uma mesa de aço inoxidável previamente higienizada. Os operadores utilizaram roupas protetoras adequadas (botas de borracha, aventais, máscaras e toucas), como parte 
integrante das condições mínimas de assepsia. A água utilizada no processamento foi destilada e pré-resfriada a $5^{\circ} \mathrm{C}$.

As etapas do processamento consistiram em:

1. Corte e Descascamento: os frutos foram cortados em rodelas, com $3,0 \mathrm{~cm}$ de largura. As sementes da "cabeça" foram retiradas com o auxílio de uma colher (a parte esponjosa junto às sementes também foi removida). Em seguida, foi removida a casca. Após, as fatias foram seccionadas em pedaços menores, com tamanhos uniformes, na forma de cubos $(3,0 \mathrm{~cm} \times 3,0 \mathrm{~cm} \times$ $3,0 \mathrm{~cm})$. Todo processo foi realizado com auxílio de faca inoxidável afiada.

2. Lavagem: após o corte, os pedaços sofreram uma lavagem com água destilada, tendo como finalidade a retirada de suco celular extravasado durante o corte, para que este não interfira na etapa de sanitização.

3. Sanitização (Higienização): os pedaços foram submersos em uma solução com sanitizante que tem como princípio ativo o Dicloro-S-Triazinatriona Sódica Diidratada, obtendo-se uma concentração final de $200 \mathrm{ppm}$ de cloro ativo, os pedaços permaneceram imersos durante 3 minutos.

4. Enxágüe: os pedaços foram enxaguados através da imersão dos mesmos em água destilada, com 3ppm de cloro ativo, para a remoção do excesso de cloro. Foi utilizado o mesmo sanitizante.

5. Drenagem: os pedaços foram colocados em escorredor doméstico previamente higienizado, para a retirada do excesso de água do enxágüe, pois o excesso de umidade pode propiciar o crescimento microbiano dentro das embalagens.

6. Pesagem e Embalagem: foram confeccionadas embalagens de $300 \mathrm{~g}$ de abóbora minimamente processada. Os pedaços foram colocados em bandejas de poliestireno expandido, cobertos com filme de PVC com $12 \mu \mathrm{m}$ de espessura (vide ANEXO A). 


\section{Tratamentos}

As abóboras minimamente processadas foram armazenadas durante 12 dias em temperatura de $1 \pm 1^{\circ} \mathrm{C} ; 5 \pm 1^{\circ} \mathrm{C}$ e $10 \pm 1^{\circ} \mathrm{C}$ e umidade relativa de $85-90 \%$. As avaliações físicas, químicas e físico-químicas foram realizadas aos $0,3^{\circ}, 6^{\circ}$, $9^{\circ}$ e $12^{\circ}$ dia de armazenamento.

A temperatura de $1^{\circ} \mathrm{C}$ foi escolhida por estar próxima da temperatura de armazenamento ideal $\left(0^{\circ} \mathrm{C}\right)$, recomendada por vários autores. À temperatura de $1^{\circ} \mathrm{C}$ se houvessem oscilações na temperatura estas não chegariam em temperaturas negativas, evitando dessa maneira o congelamento dos tecidos.

Escolheu-se a temperatura de $5^{\circ} \mathrm{C}$, pois é a temperatura de armazenamento mais próxima do ideal e que se torna economicamente viável.

A temperatura de $10^{\circ} \mathrm{C}$ foi utilizada por ser a temperatura comumente utilizada nas gôndolas dos supermercados para conservação dos produtos minimamente processados.

\section{Análises físicas, químicas e físico-químicas}

\section{$\underline{\text { Taxa respiratória }}$}

Aproximadamente $150 \mathrm{~g}$ do produto MP foram colocadas em frascos de vidro com capacidade de $600 \mathrm{~mL}$, permanecendo hermeticamente fechados por períodos de 1 hora. Em cada tampa dos frascos foi colocado um septo de silicone através do qual foi retirada a amostra de gás. Com uma seringa de vidro foi coletada uma amostra de $1 \mathrm{~mL}$ de cada frasco e injetada em cromatógrafo a gás (Thermoquest GC Trace 2000) com detector de ionização de chama (FID), tendo hidrogênio como gás de arraste a um fluxo de $25 \mathrm{~mL}$ minuto $^{-1}$. As temperaturas foram $80^{\circ} \mathrm{C}$ na coluna, $100^{\circ} \mathrm{C}$ no injetor, $250^{\circ} \mathrm{C}$ no detector e $350^{\circ} \mathrm{C}$ no metanador. Os resultados expressos em ppm de $\mathrm{CO}_{2}$ foram transformados para $\%$ de $\mathrm{CO}_{2}$ e utilizados para ao cálculo da taxa respiratória, sendo levado em conta o volume livre do frasco, o tempo que o mesmo permaneceu fechado e a massa das abóboras MP. No dia do 
processamento (dia 0) foram feitas leituras a cada hora por um período de 4 horas, posteriormente, as leituras foram realizadas diariamente (a cada 24 horas), durante 12 dias. $\mathrm{O}$ resultados foram expressos em $\mathrm{mL} \mathrm{CO} \mathrm{kg}^{-1} \mathrm{~h}^{-1}$.

\section{Produção de etileno}

Os procedimentos para determinação da taxa de produção de etileno foram semelhantes ao utilizado para a determinação da taxa respiratória, no que se refere a coleta da amostra de gás, porém as amostras permaneceram fechadas por um período de 2 horas. A amostra foi injetada em cromatógrafo a gás (Thermoquest GC Trace 2000) com detector de ionização de chama (FID), tendo hidrogênio como gás de arraste a um fluxo de $25 \mathrm{~mL} /$ minuto, as temperaturas da coluna, injetor e detector foram de $80^{\circ} \mathrm{C}, 100^{\circ} \mathrm{C}, 100^{\circ} \mathrm{C}$ respectivamente. Os resultados foram expressos em $\mu \mathrm{L} \mathrm{C}_{2} \mathrm{H}_{4} \mathrm{~kg}^{-1} \mathrm{~h}^{-1}$.

\section{Perda de massa}

Foi determinada pela diferença, em \%, entre a massa inicial e final da repetição, através de uma balança digital.

\section{Coloração}

Foi utilizado um colorímetro marca Minolta, com iluminante D65, realizando-se as leituras de $L$ (luminosidade), $a^{*}, b^{*}$, sendo estes dados transformados em $C^{*}$ (cromaticidade) através de fórmula $\left(C=\sqrt{ } a^{* 2}+b^{* 2}\right)$ e $h^{0}$ (ângulo de cor) pela fórmula $h^{0}=\operatorname{tg}^{-1} \cdot b^{*} / a^{*}$.

\section{Firmeza de polpa}

Foi determinada com o auxílio de penetrômetro manual, com ponteira de $8 \mathrm{~mm}$ de diâmetro. Os resultados foram expressos em Newton. 


\section{Teor de sólidos solúveis}

Após a trituração da amostra em centrífuga doméstica, uma gota do suco proveniente da trituração da amostra foi colocada em um refratômetro digital (Atago). Os resultados foram expressos em ${ }^{\circ}$ Brix.

\section{Acidez titulável}

Foi determinada por titulação com $\mathrm{NaOH} 0,1 \mathrm{~N}$ até $\mathrm{pH} 8,1$, com os resultados expressos em \% de ácido málico.

\section{$\underline{T e o r}$ de ácido ascórbico}

Foram utilizadas $10 \mathrm{~g}$ de amostra triturada e colocadas em erlenmeyer contendo $50 \mathrm{ml}$ de solução de ácido oxálico. A titulação foi efetuada com o indicador DCFI (2,6-diclorofenol indolfenol-sódio) até atingir a coloração rosada persistente por 15 segundo. Os resultados foram expressos em $\mathrm{mg}$ de ácido ascórbico por $100 \mathrm{~g}$ de polpa (Carvalho et al, 1990).

\section{$\underline{\text { Teor de carotenóides totais }}$}

Foi determinado por espectrofotometria, onde em $5 \mathrm{~g}$ de amostra, triturada em almofariz com $3 \mathrm{~g}$ de Hyflosupercel (celite) e $50 \mathrm{~mL}$ de acetona gelada, foi filtrada (a vácuo) em funil de Buchner com filtro de papel. Parte da amostra filtrada foi colocada funil de separação contendo $40 \mathrm{~mL}$ de éter de petróleo, adicionaram-se $300 \mathrm{~mL}$ de água destilada, pelas paredes do funil para evitar a formação de emulsão, para formação de duas fases (éter de petróleo + carotenóides e água + acetona). Em seguida, descartou-se a fase aquosa, acrescentando-se mais uma parte da amostra filtrada, efetuando-se o mesmo procedimento com $200 \mathrm{~mL}$ de água destilada (o procedimento foi efetuado de 3 a 4 vezes). Após a remoção de toda acetona a fase com éter de petróleo foi filtrada em filtro de vidro contendo $15 \mathrm{~g}$ de sulfato de sódio anidro (para retirada de água) e colocada em balão ( $50 \mathrm{~mL}$ ) completando-se o volume com éter de petróleo. Realizaram-se leituras e espectrofotômento (FEMTO-700 Plus), na 
faixa de absorbância de 450nm. As leituras foram utilizadas para o cálculo da quantidade de carotenóides totais utilizando-se a fórmula: $[A x$ volume $(\mathrm{mL}) \mathrm{x}$ $\left.10^{4}\right] /\left[A_{1 \mathrm{~cm}}^{1 \%} \times\right.$ peso da amostra $\left.(\mathrm{g})\right]$, onde $A=$ absorbância; volume=volume da amostra $(50 \mathrm{~mL}) ; A^{1 \%}{ }_{1 \mathrm{~cm}}=$ coeficiente de absorção do $\beta$-caroteno em éter de petróleo (2592). Os resultados foram expressos em $\mu \mathrm{g} / \mathrm{g}$ (Rodriguez-Amaya \& Kimura, 2004).

\section{Análises microbiológicas}

As análises microbiológicas foram realizadas no dia do processamento (dia 0$), 6^{\circ}$ e $12^{\circ}$ dias de armazenamento.

A microflora contaminante da abóbora minimamente processada foi avaliava pela contagem total de bactérias pscicrotróficas, número mais provável (NMP) de coliformes totais e fecais e presença ou ausência de Salmonella, conforme estabelecida pela Resolução RDC n 12 de 02/01/2001, da Agência Nacional de Vigilância Sanitária (ANVISA).

As análises para contagem de bactérias psicrotróficas e para o NMP de coliformes foram efetuadas em porções de $50 \mathrm{~g}$ de abóboras para cada repetição, que foram pesadas assepticamente e colocadas em erlenmeyers contendo $450 \mathrm{~mL}$ de água peptonada $(0,1 \%)$ estéril, constituindo a diluição $10^{-1}$. Da de diluição de $10^{-1}$, obteve-se a diluição de $10^{-2}$, pipetando-se $10 \mathrm{~mL}$ da solução $10^{-1}$ em colocando e $90 \mathrm{~mL}$ de água peptonada $(0,1 \%)$ esterilizada e a partir da diluição de $10^{-2}$, obteve-se a diluição de $10^{-3}$ pelo mesmo processo.

\section{Contagem total de bactérias psicrotróficas}

Decidiu-se fazer contagem de bactérias pscicrotróficas, pois como as abóboras irão ser armazenadas sob refrigeração, nestas temperaturas se não houver crescimento de bactérias pscicrotróficas, conseqüentemente não irá haver crescimento das bactérias mesófilas. Para contagem de bactérias psicrotróficas (qualquer bactéria cujo ótimo de temperatura para crescimento 
situa-se acima de $20^{\circ} \mathrm{C}$, porém toleram e crescem sob refrigeração), utilizou-se o meio Ágar Padrão para Contagem (PCA).

O princípio desta metodologia baseia-se na capacidade que cada célula microbiana, presente na amostragem, tem de formar uma colônia visível e isolada, uma vez fixada em um meio de cultura sólido para seu desenvolvimento (Silva, et al., 2001).

A partir da diluição de $10^{-1}$ até a $10^{-3}$ as amostras de abóboras minimamente processadas, foram plaqueadas em profundidade colocando-se $1 \mathrm{~mL}$ de cada diluição em duplicata, utilizando-se $20 \mathrm{~mL}$ de meio de cultivo PCA. Após o plaqueamento, as placas permaneceram em repouso até completa solidificação do meio, sendo, então invertidas e incubadas, em geladeira, a $7^{\circ} \mathrm{C}$ por 10 dias.

Decorrido o tempo de incubação foram selecionadas as placas e fez-se a contagem das mesmas, com auxílio do contador de colônias tipo Quebec. Os resultados foram expressos em UFC/g.

\section{NMP (Número Mais Provável) de coliformes totais e fecais}

Os coliformes totais e fecais foram determinados pelo método do NMP, através da técnica de Tubos Múltiplos.

A técnica de Tubos Múltiplos possui duas etapas distintas: i) teste presuntivo, onde se busca detectar a presença de microrganismos fermentadores de lactose e onde é possível recuperar células injuriadas; ii) teste confirmativo, através do qual pode se determinar a população real de coliformes totais e fecais.

Para o teste presuntivo foram utilizadas três séries de cinco tubos de ensaios, o quais continham cada um, um tudo de Durham (invertido) e $15 \mathrm{~mL}$ de Caldo Lactosado ( $\mathrm{CL}$ ), um meio cuja fonte de carbono é a lactose que é fermentada pelas bactérias do grupo coliforme, com produção de ácido e gás. Na primeira série, colocou-se $1 \mathrm{~mL}$ da diluição $10^{-1}$ (anteriormente citada) em 
cada um dos 5 tubos de ensaio, sendo realizado o mesmo procedimento para as demais séries de tubos com as diluições de $10^{-2}$ e $10^{-3}$.

Todos os tubos foram incubados em estufa termostatizada a $35-37^{\circ} \mathrm{C}$, por 24-48 horas. Após 24 e 48 horas de incubação verificou-se a positividade dos resultados, os tubos positivos apresentaram o esvaziamento dos tubos de Durham, devido à produção de gás pelas bactérias do grupo coliforme ao fermentarem a lactose.

Em caso de positividade do teste presuntivo, alíquotas tubos positivos do teste de presuntivo foram transferidas para o teste confirmativo, verificando-se, assim, se realmente tratavam-se de bactérias do grupo coliforme.

Utilizando-se alça de níquel-cromo, foram inoculados tubos de Caldo Verde Brilhante Lactose Bile (CVBLB), em concentração simples, e tubos de Caldo EC, correspondentes aos tubos positivos da fase anterior.

Os tubos de CVBLB foram inoculados em estufa termostatizada à temperatura de $35-37^{\circ} \mathrm{C}$ durante $24-28 \mathrm{~h}$, sendo verificada, após esse período, a formação ou não de gás nos tubos de Durham. A formação de gás em CVBLB confirma a presença de bactérias do grupo coliforme, podendo ser de origem fecal ou não, denominadas coliformes totais.

Os tubos de EC, uma vez inoculados, foram incubados em banho-maria termostatizado à temperatura de $45^{\circ} \mathrm{C}$ por 24 horas. Após o período de incubação, a formação de gás em EC confirma a presença de coliformes a $45^{\circ} \mathrm{C}$.

A partir do número de tubos positivos em cada série de ambos os meios, consultando-se seus valores correspondentes na tabela da Associação Brasileira de Normas Técnicas MB 3463 (vide anexo), obteve-se o NMP de coliformes totais (CVBLB) e coliformes a $45^{\circ} \mathrm{C}$ (Caldo $\mathrm{EC}$ ), por grama de abóbora minimamente processada. 


\section{Detecção de Salmonella}

Para detecção de Salmonella, utilizou-se o Kit '1-2 Test', fabricado pela Biocontrol/USA. Trata-se de um método oficial aprovado pela AOAC (Association of Analytical Chemists Internacional) para utilização em todo os tipos de alimentos.

Foi feito um pré-enriquecimento de cada amostra analisada, colocando-se $25 \mathrm{~g}$ da abóbora minimamente processada em um erlenmeyer contendo $225 \mathrm{~mL}$ de água peptonada tamponada esterilizada. Os erlenmeyers foram incubados em estufa termostatizada, a $35^{\circ} \mathrm{C}$ por 24 horas. O pré-enriquecimento é possível pela exigência de ausência de Samonella em $25 \mathrm{~g}$ de qualquer alimento para consumo humano analisado. Deste modo se a bactéria estiver presente no alimento, não importando o número de bactérias, o alimento é considerado impróprio para consumo humano. Com o pré-enriquecimento, a multiplicação da bactéria é favorecida, facilitando a detecção na análise, uma vez que tal patógeno encontra-se normalmente em níveis baixos nos alimentos.

Decorrido o período de incubação, do pré-enriquecimento, fez-se o preparo dos kits, compostos, cada um, de dois compartimentos. A amostra préenriquecida $(0,1 \mathrm{~mL})$ foi colocada na câmara de incubação onde, primeiramente foi adicionada uma gota de solução de iodo-iodeto e depois removido o tampão desta câmara com auxílio de uma pinça estéril. A outra câmara, de motilidade, contém um meio de motilidade não seletivo, a base de peptona. Esta câmara é fechada por uma pequena ponteira (que foi removida) para formar um vão no gel, em seguida, adicionou-se uma gota da solução de anticorpos polivalente anti-Salmonella. Os kits foram incubados a $35^{\circ} \mathrm{C}$ por 24 horas. Após a incubação foi feita a leitura dos resultados.

A possível presença de Salmonella é caracterizada pela formação de uma imunobanda na metade superior do gel na câmara da motilidade. Trata-se de uma banda branca em forma de $U$ formada pela aglutinação das células da bactéria com a solução de anticorpos. 


\section{Delineamento experimental e análise dos resultados}

O delineamento experimental foi inteiramente casualizado em esquema fatorial $3 \times 5$. Os fatores estudados foram: temperatura, em três níveis (1, $5 \mathrm{e}$ $10^{\circ} \mathrm{C}$ ), e tempo de armazenamento, em cinco níveis $(0,3,6,9$ e 12 dias). Foram utilizadas quatro repetições por tratamento, sendo cada uma composta de $300 \mathrm{~g}$ de abóbora minimamente processada. Para a caracterização do lote experimental (tempo zero), quatro amostras foram analisadas logo após o processamento do produto.

Os resultados obtidos das análises físicas químicas e físico-químicas foram submetidos à análise do erro padrão. As diferenças entre dois tratamentos maior que a soma dos erros padrões foram consideradas significativas $(P<0,05)$ (Moretti et al., 2002).

Para avaliação dos aspectos microbiológicos os resultados foram expressos em UFC/g de produto para bactérias psicrotróficas, NMP/g para coliformes totais e presença ou ausência de Salmonella em $25 \mathrm{~g}$ de produto.

\subsection{Resultados e Discussão}

\section{Taxa Respiratória}

As taxas respiratórias de abóboras minimamente processadas apresentaram decréscimos durante as primeiras horas de armazenamento, independentemente da temperatura de armazenamento (Figura 1). Resultado semelhante foi obtido por Smyth et al. (1998) em alfaces minimamente processadas, onde a taxa de produção de $\mathrm{CO}_{2}$ decresceu de aproximadamente 470 pmol.g $\mathrm{g}^{-1} \mathrm{~s}^{-1}$ (1 hora após o processamento) para 125pmol.g $\mathrm{g}^{-1} \mathrm{~s}^{-1}$ (24 horas após o corte). Produções elevadas de $\mathrm{CO}_{2}$ imediatamente após o corte e decréscimo na evolução do $\mathrm{CO}_{2}$ durante o período de armazenamento têm sido relatadas por diversos autores (Sigist, 2002). 


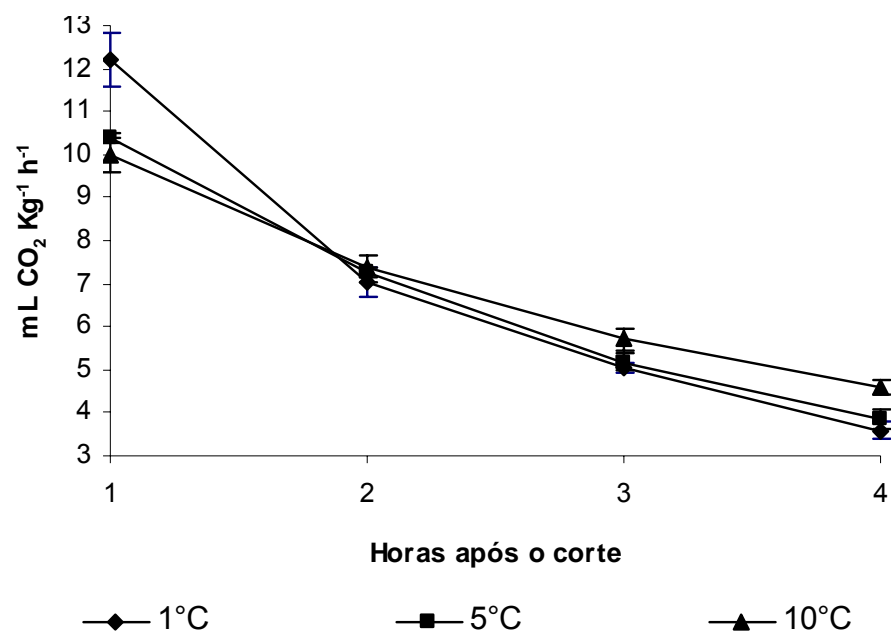

Figura 1 - Taxa respiratória logo após o corte de abóboras minimamente processadas armazenadas em diferentes temperaturas. Barras verticais representam o erro padrão da média

As abóboras minimamente processadas armazenadas a $10^{\circ} \mathrm{C}$ apresentaram maiores taxas de respiração ao longo do período de armazenamento, em relação às mesmas armazenadas a $1^{\circ} \mathrm{C}$ e $5^{\circ} \mathrm{C}$ (Figura 2). As abóboras armazenadas a $10^{\circ} \mathrm{C}$ atingiram pico de até $34,27 \mathrm{~mL} \mathrm{CO}_{2} \mathrm{Kg}^{-1} \mathrm{~h}^{-1}$, no $3^{\circ}$ dia, enquanto que as mantidas a $1^{\circ} \mathrm{C}$ e $5^{\circ} \mathrm{C}$ tivera picos máximos de $9,66 \mathrm{~mL} \mathrm{CO} \mathrm{Kg}^{-1} \mathrm{~h}^{-1}$ e 8,58mL CO $\mathrm{Kg}^{-1} \mathrm{~h}^{-1}$, respectivamente, no mesmo dia. As temperaturas de 1 e $5^{\circ} \mathrm{C}$ não apresentaram diferença significativa entre si, ao longo do período de armazenamento.

O pico respiratório observado nas abóboras minimamente processadas, independentemente da temperatura, advém de um estresse provocado pelo processamento. Este estresse provoca a perda da compartimentação celular e com isso os substratos do metabolismo respiratório entram em contato com os complexos enzimático resultando num aumento da taxa respiratória. A redução subseqüente da taxa respiratória a partir do $6^{\circ}$ dia ainda não é bem explicada, mas é possível que haja uma auto-regulação da atividade respiratória do tecido devido a grande produção de ATP (Purvis, 1997), ou que esta redução da taxa 
respiratória ocorra pelo fato dos substratos respiratórios pararem de reagir com as enzimas presentes nas células da superfície do corte.

Vários têm sido os estudos que mostram a influência da temperatura na atividade metabólica dos vegetais minimamente processados. Habibunnisa et al. (2001), estudando abóboras do tipo moranga (Cucúrbita maxima), minimamente processadas, verificaram diminuição dos valores de $157,54 \mathrm{mg}$ $\mathrm{CO}_{2} \mathrm{Kg}^{-1} \mathrm{~h}^{-1}$ a $28^{\circ} \mathrm{C}$, para $25,26 \mathrm{mg} \mathrm{CO}_{2} \mathrm{Kg}^{-1} \mathrm{~h}^{-1}$, quando as mesmas foram armazenadas a $5^{\circ} \mathrm{C}$. Hong \& Kim (2001), em estudos para verificar o efeito da temperatura sobre a taxa de respiração de cebolinhas minimamente processada cortadas em $10 \mathrm{~cm}$ de comprimento, verificaram níveis de $9,19 \mathrm{~mL}$ $\mathrm{CO}_{2} \mathrm{Kg}^{-1} \mathrm{~h}^{-1} ; 27,02 \mathrm{~mL} \mathrm{CO}_{2} \mathrm{Kg}^{-1} \mathrm{~h}^{-1}$ e $78,74 \mathrm{~mL} \mathrm{CO}_{2} \mathrm{Kg}^{-1} \mathrm{~h}^{-1}$ em temperaturas de $0^{\circ} \mathrm{C}, 10^{\circ} \mathrm{C}$ e $20^{\circ} \mathrm{C}$, respectivamente. Sigrist (2002), estudando o efeito de diferentes temperaturas no metabolismo de couves-flores minimamente processado cortadas em floretes, observou que o produto armazenado a $1^{\circ} \mathrm{C}$ respirou menos $\left(37,52 \mathrm{mg} \mathrm{CO}_{2} \mathrm{~kg}^{-1} \mathrm{~h}^{-1}\right)$ que aquele armazenado a $11^{\circ} \mathrm{C}$ $\left(99,85 \mathrm{mg} \mathrm{CO}_{2} \mathrm{~kg}^{-1} \mathrm{~h}^{-1}\right)$.

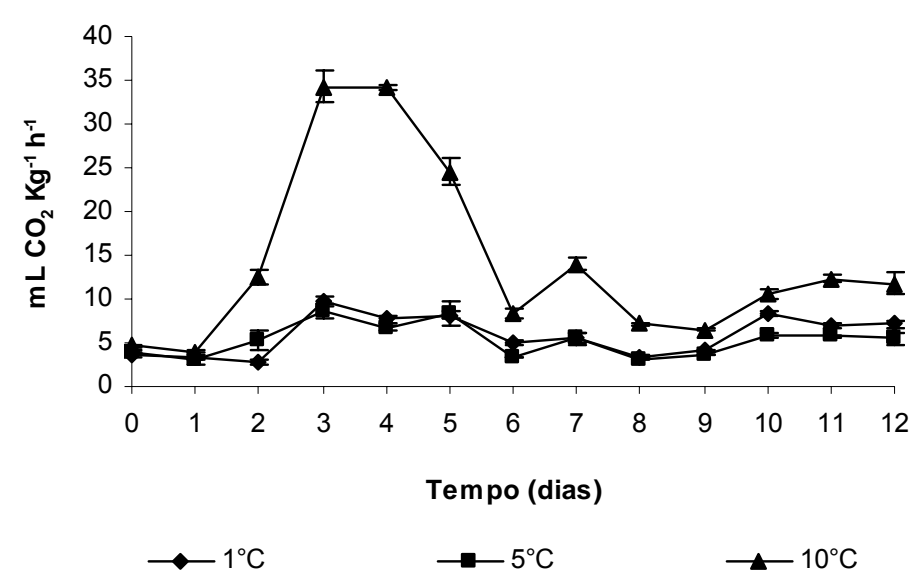

Figura 2 - Taxa respiratória de abóboras minimamente processadas armazenadas em diferentes temperaturas. Barras verticais representam o erro padrão da média 
Estes estudos com morangas, cebolinhas e abóbora estão de acordo com vários outros dados de diferentes hortaliças mostrados por Watada et al. (1996), confirmando que as taxas respiratórias de vegetais minimamente processados aumentam com a elevação da temperatura e que o grau deste aumento varia em função do material vegetal.

\section{Produção de Etileno}

Não foi detectada a produção de etileno durante as 4 primeiras horas após o corte, em nenhuma das temperaturas. Não foi detectada, também, a produção de etileno a $1^{\circ} \mathrm{C}$, durante todo período de armazenamento, talvez, porque a quantidade de etileno produzido pela abóbora nesta temperatura seja muito baixa e não consiga ser detectado pelo cromatógrafo utilizado, que determina valores maiores ou iguais a $0,03 \mu \mathrm{L} \mathrm{C}_{2} \mathrm{H}_{4} \mathrm{Kg}^{-1} \mathrm{~h}^{-1}$.

As abóboras minimamente processadas mantidas a $10^{\circ} \mathrm{C}$ apresentaram um pico de produção de etileno no $3^{\circ}$ dia de armazenamento, atingindo valores de $24,49 \mu \mathrm{L} \mathrm{C}_{2} \mathrm{H}_{4} \mathrm{Kg}^{-1} \mathrm{~h}^{-1}$, produção essa 6 vezes maior que a das abóboras armazenadas a $5^{\circ} \mathrm{C}$. Após o $3^{\circ}$ dia, a taxa de produção de etileno das abóboras mantidas a $10^{\circ} \mathrm{C}$ começou da decrescer, chegando a valores próximo das abóboras armazenadas a $5^{\circ} \mathrm{C}$. As abóboras mantidas a $5^{\circ} \mathrm{C}$ tiveram seu pico de produção de etileno no $4^{\circ}$ dia (Figura 3 ). 


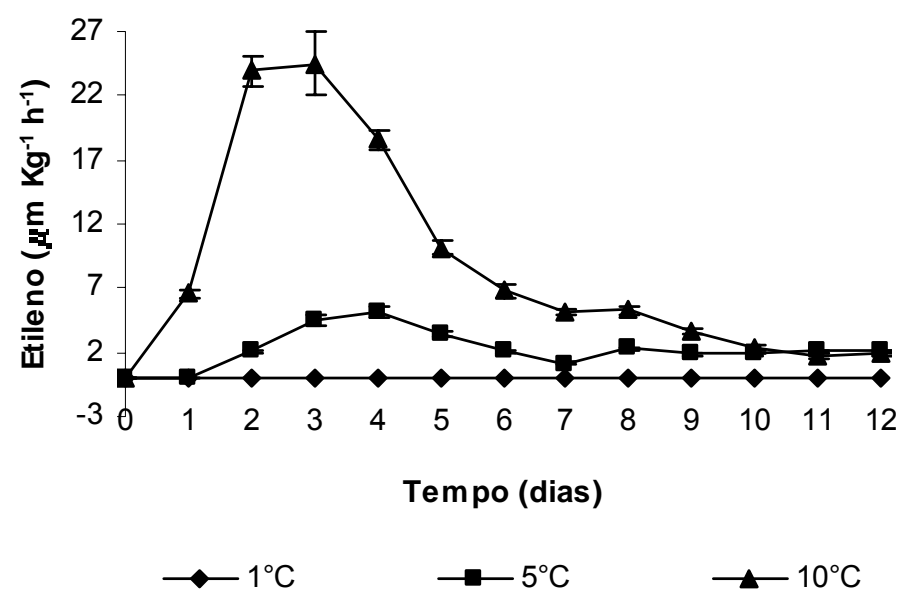

Figura 3 - Taxa de produção de etileno de abóboras minimamente processadas armazenadas em diferentes temperaturas. Barras verticais representam o erro padrão da média

Mertens \& Tranggono (1989) observaram que couves-flores armazenadas a $1^{\circ} \mathrm{C}$ produziam menos que $0,03 \mu \mathrm{L}_{2} \mathrm{H}_{4} \mathrm{Kg}^{-1} \mathrm{~h}^{-1}$ e quase $0,1 \mu \mathrm{L}$ $\mathrm{C}_{2} \mathrm{H}_{4} \mathrm{Kg}^{-1} \mathrm{~h}^{-1}$, quando armazenadas a $10^{\circ} \mathrm{C}$.

De acordo com Sakr et al. (1997), o aumento da produção de etileno pode ser uma resposta hormonal e bioquímica devido ao estresse causado pelo corte. Isto ocorre, pois o primeiro alvo desse estresse é a membrana plasmática, a qual responde com mudanças em suas características físicas, de forma a contornar tais perturbações e tentar repara os danos causados durante o processamento. $\mathrm{O}$ aumento da produção de etileno em temperaturas mais elevadas é devido às atividades metabólicas e velocidades das reações enzimáticas serem mais rápidas. De acordo com a Lei de Vant'Hoff $\left(Q_{10}\right)$, a qual diz que, de uma maneira geral, a velocidade das reações biológicas aumenta de duas a três vezes para cada $10^{\circ} \mathrm{C}$ de aumento de temperatura, dentro de uma faixa fisiológica.

Segundo Brecht (1995), o aumento da taxa de respiração em tecido que sofreram ferimentos, pode ser conseqüência do aumento da produção de etileno o qual estimula a respiração. Isto pode ser constatado nas abóboras minimamente processadas, comparando-se a Figura 2 e 3 pode-se observar 
que os picos respiratórios tanto a temperatura de $5^{\circ} \mathrm{C}$ como na temperatura de $10^{\circ} \mathrm{C}$ (Figura 2), são antecedidos por um pico na produção de etileno (Figura 3). Como a produção de etileno é maior a temperatura de $10^{\circ} \mathrm{C}$, conseqüentemente, há uma maior taxa respiratória nesta temperatura.

\section{Perda de massa}

.Finger \& Vieira (1997) afirmam que a perda de peso máxima, sem aparecimento de murchamento ou enrugamento da superfície, oscila entre $5 \%$ a $10 \%$ e que a perda de peso aceitável para os produtos hortícolas varia de em função da espécie e do nível de exigência dos consumidores.

Embora os valores tenham ficado abaixo dos valores críticos de perda de massa indicados por Finger \& Vieira (1997), houve um aumento de perda de massa, ao longo do período de armazenamento, independentemente da temperatura de armazenamento (Figura 4). Esta perda de massa relativamente pequena pode ser atribuída à proteção oferecida pela embalagem.

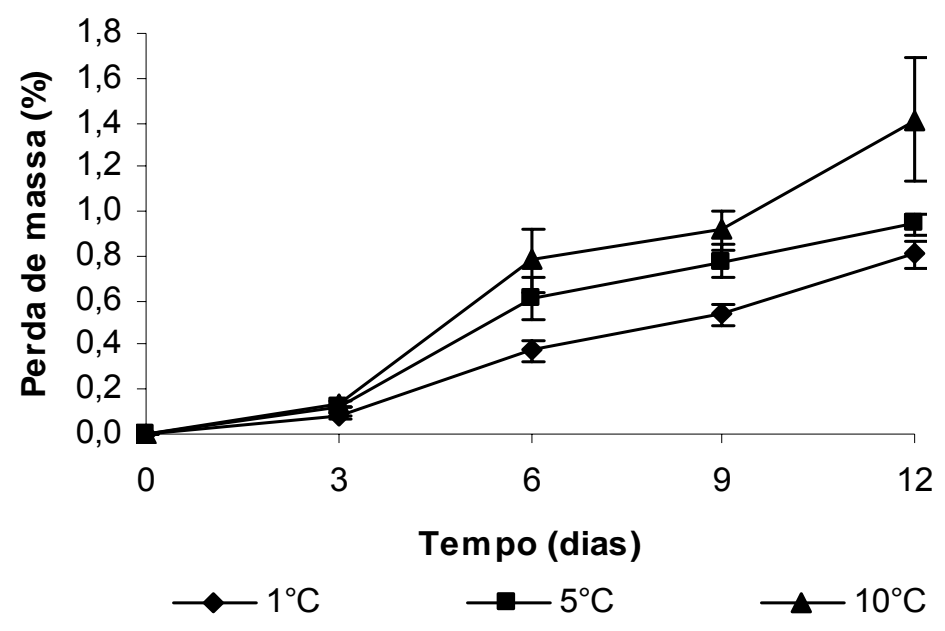

Figura 4 - Perda de massa de abóboras minimamente processadas armazenadas em diferentes temperaturas. Barras verticais representam o erro padrão da média

As abóboras armazenadas a $10^{\circ} \mathrm{C}$ tiveram uma perda de massa maior durante o período de armazenamento, atingindo valores de 1,41\%. As abóboras armazenadas a $1^{\circ} \mathrm{C}$ apresentaram menor perda, ficando as abóboras 
armazenadas a $5^{\circ} \mathrm{C}$ com valores intermediários. Isto ocorre porque o déficit de pressão de vapor (DPV) é maior em temperaturas mais elevadas.

Segundo Carvalho \& Lima (2000) a perda de massa fresca ao logo do período de armazenamento tem sido atribuída à perda de umidade e de material de reserva pela transpiração e respiração, respectivamente. As perdas de água, através da transpiração, influenciam diretamente no processo de degradação da qualidade dos produtos minimamente processados (BemYehoshua, 1985). A perda de massa fresca pode resultar, não somente em perdas quantitativas, mas também comprometer a aparência, a textura e a qualidade nutricional dos produtos (Kader, 1992).

\section{Firmeza}

No presente experimento, observou-se que não houve perda de firmeza nas temperaturas de $1^{\circ} \mathrm{C}$ e $5^{\circ} \mathrm{C}$, e houve um aumento da firmeza nas abóboras armazenadas a $10^{\circ} \mathrm{C}$ atingindo valores de 83,3 newtons (Figura 5).

González-Aguilar et al.(2004) observaram redução na firmeza de pimentões minimamente processados armazenados a $5^{\circ} \mathrm{C}$ e $10^{\circ} \mathrm{C}$, independentemente da temperatura de armazenamento.

Varoquaux (1987) afirma que as lesões causadas durante o próprio processamento acarretam na descompartimentação celular colocando em contato substratos e enzimas que dão origem a diferentes alterações bioquímicas como odores desagradáveis e a perda da firmeza. 


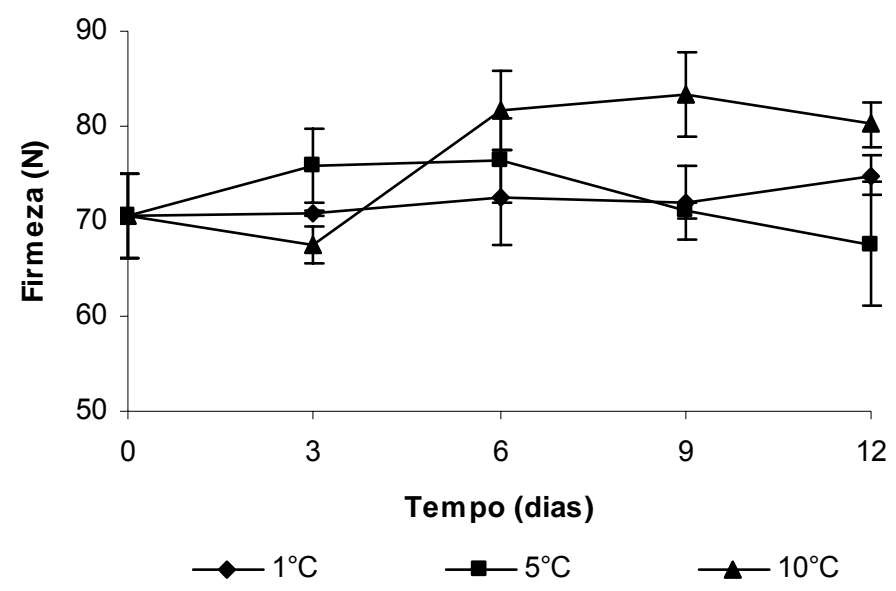

Figura 5 - Valores de firmeza (Newtons) de abóboras minimamente processadas armazenadas em diferentes temperaturas. Barras verticais representam o erro padrão da média

$\mathrm{O}$ aumento da firmeza das abóboras a $10^{\circ} \mathrm{C}$ deve ter ocorrido devido a maior perda de água das mesmas (Figura 4), o que pode ter levado a um murchamento dos pedaços e conseqüentemente dificultado a penetração do penetrômetro. Sarzi (2002), ao avaliar a evolução da textura em mamão 'Formosa', também registrou aumento significativo da firmeza, e associou tal fato à perda de umidade, com a formação de camada superficial mais firme.

\section{Sólidos solúveis}

No caso das abóboras minimamente processadas, em todos os tratamentos ocorreu um decréscimo nos teores de sólido solúveis, que inicialmente era de 5,48 ${ }^{\circ} \mathrm{Brix}$, chegando a valores de 5,00; 4,93 e 4,65 ${ }^{\circ} \mathrm{Brix}$, para $1^{\circ} \mathrm{C}, 5^{\circ} \mathrm{C}$ e $10^{\circ} \mathrm{C}$, no $12^{\circ}$ dia, respectivamente (Figura 6 ).

Silva et al. (2003) observaram que mandiocas minimamente processadas armazenadas a $10^{\circ} \mathrm{C}$ e $25^{\circ} \mathrm{C}$ tiveram os valores de sólidos solúveis variando entre 4 e $6^{\circ}$ Brix permanecendo próximos ao valor inicial de $5,5^{\circ}$ Brix, durante todo o período de armazenamento. Pinto (2002) também observou constância nos teores de sólidos solúveis de melão tipo Orange Fresh minimamente processados armazenados a $3^{\circ} \mathrm{C}$ e $6^{\circ} \mathrm{C}$. 
O teor de sólidos solúveis é utilizado como uma medida indireta do conteúdo de açúcares, pois seu valor aumente à medida que estes vão aumentando no fruto. A sua determinação não representa o teor exato de açúcares, pois outras substâncias também se encontram dissolvidas no conteúdo celular (vitaminas, fenóis, pectinas, ácidos orgânicos e pigmentos). No entanto, os açúcares são os mais representativos e chegam a constituir até 8590\% dos sólidos solúveis (Chitarra \& Alves, 2001).

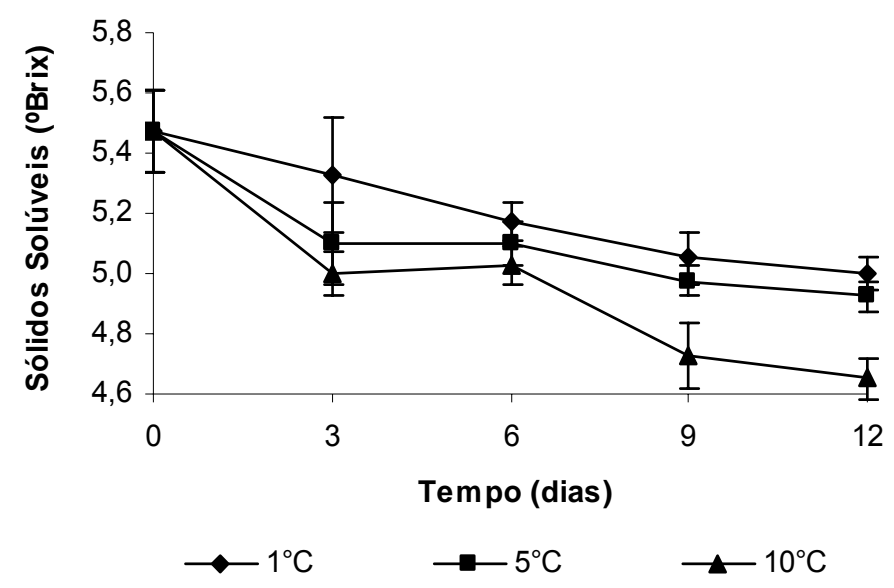

Figura 6 - Teores de sólidos solúveis ( ${ }^{\circ}$ Brix) de abóboras minimamente processadas armazenadas sob diferentes temperaturas. Barras verticais representam erro padrão da média

As abóboras armazenadas a $10^{\circ} \mathrm{C}$ sofreram maior redução nos teores de sólidos solúveis a partir do o $6^{\circ}$ dia de armazenamento. Isto porque, como a respiração consiste na decomposição oxidativa de substâncias complexas (polissacarídeos, açúcares simples, ácidos orgânicos, proteínas e lipídios) em moléculas simples $\left(\mathrm{CO}_{2}\right.$ e $\left.\mathrm{H}_{2} \mathrm{O}\right)$ e energia (Kluge et al., 2002), e quanto mais elevada à temperatura, maior é a taxa respiratória, consumindo mais substratos. Por outro lado, baixas temperaturas durante o armazenamento retardam o metabolismo do vegetal através da diminuição de sua taxa respiratória (Chitarra \& Chitarra, 1990) e, conseqüentemente, evitam reduções drásticas nos teores de sólidos solúveis, como pode ser observado na Figura 6 , onde as abóboras armazenadas a 1 e $5^{\circ} \mathrm{C}$ tiveram menores reduções nos 
teores de sólidos solúveis, em relação a mesmas armazenadas a $10^{\circ} \mathrm{C}$. Não houve diferença significativa entre as abóboras armazenadas a 1 e $5^{\circ} \mathrm{C}$, durante o período de armazenamento.

Segundo Teles (2001), a concentração de sólidos solúveis é considerada uma variável da qualidade de frutas e hortaliças frescas e pode indicar a ocorrência da desidratação do produto e/ou a alta taxa respiratória, resultando no consumo de reservas energéticas. $O$ autor atribuiu à respiração a causa da redução de sólidos solúveis, observada em couves minimamente processadas mantidas a 5 e $10^{\circ} \mathrm{C}$.

\section{Acidez titulável}

Os teores de acidez titulável se mantiveram estáveis ao longo do período de armazenamento, independentemente da temperatura. Os valores iniciais foram $0,078 \%$ (dia 0) e se mantiveram a valores de 0,083\%, 0,104\% e 0,093\% para as temperaturas de $1^{\circ} \mathrm{C}, 5^{\circ} \mathrm{C}$ e $10^{\circ} \mathrm{C}$, respectivamente (Figura 7 ).

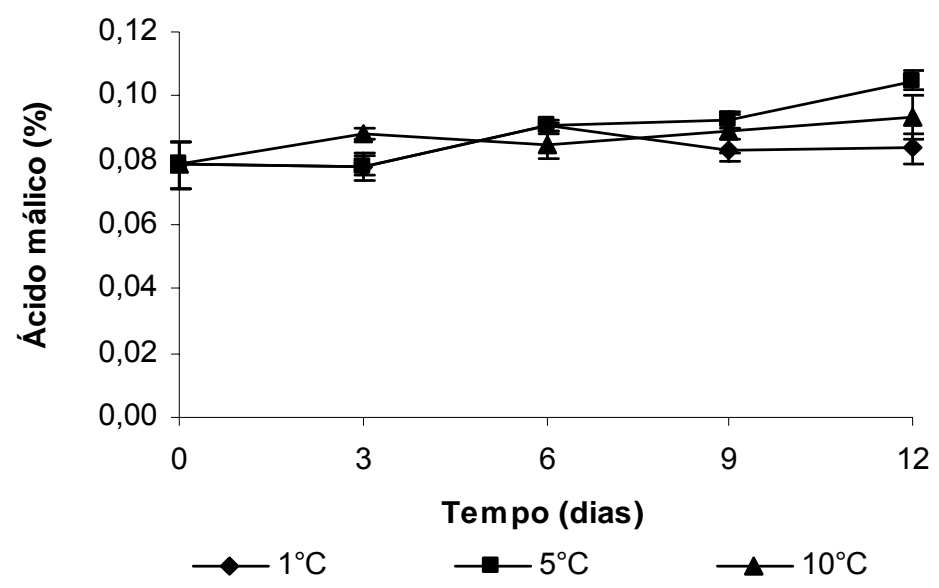

Figura 7 - Valores de acidez titulável (\% ácido málico) de abóboras minimamente processadas armazenadas sob diferentes temperaturas. Barras verticais representam erro padrão da média

Vários autores notaram comportamentos semelhantes em diferentes vegetais minimamente processados. Pinto (2002) observou que melões de tipo Orange Fresh armazenados a 3 e $6^{\circ} \mathrm{C}$ apresentam valores constantes na acidez titulável. Spagnol (2004) estudando cenouras minimamente 
processadas armazenadas a 1,5 e $11^{\circ} \mathrm{C}$, também observou que os valores de acidez titulável se mantiveram constantes ao logo do armazenamento, sendo os valores mais baixo notados a $11^{\circ} \mathrm{C}\left(0,0640 \mathrm{mg}\right.$ de ácido málico $\left.100 \mathrm{~g}^{-1}\right)$, enquanto à temperatura de $1^{\circ} \mathrm{C}$ apresentou em média $0,0730 \mathrm{mg}$ de ácido málico $100 \mathrm{~g}^{-1}$.

\section{Ácido ascórbico}

A vitamina C é definida como um termo genérico para todos os compostos que apresentam a atividade biológica semelhante ao L-ácido ascórbico (AA). O AA é a principal forma biologicamente ativa da vitamina $C$, mas o ácido L-dehidroascórbico (DHA), um produto da oxidação do $A A$, também exibe atividade biológica (Lee \& Kader, 2000).

Para todas as temperaturas de armazenamento, os teores de ácido ascórbico tenderam a diminuir ao longo do armazenamento (Figura 8). Segundo Franco (1998), a redução nos teores de vitamina C ocorre porque o ácido ascórbico sofre degradação devido ao calor, oxidação, dessecação, armazenamento, aplicação de frio e alcalinidade do meio. Adicionalmente, os danos provocados pelo processamento mínimo estimulam reações antioxidativas de defesa nos produtos o que pode ter consumido o ácido ascórbico. A redução mais acentuada no teor de ácido ascórbico ocorreu a $10^{\circ} \mathrm{C}$. Isso pode ser devido ao fato que em temperaturas mais elevadas, o metabolismo tende a ser mais acelerado, incluindo as reações anti-oxidativas, o que pode ter consumindo maiores quantidades de ácido ascórbico. 


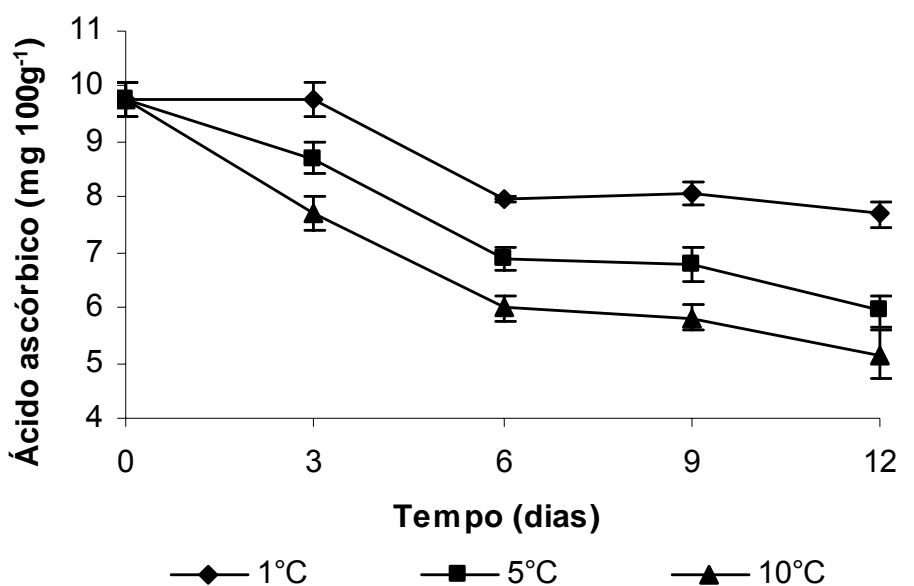

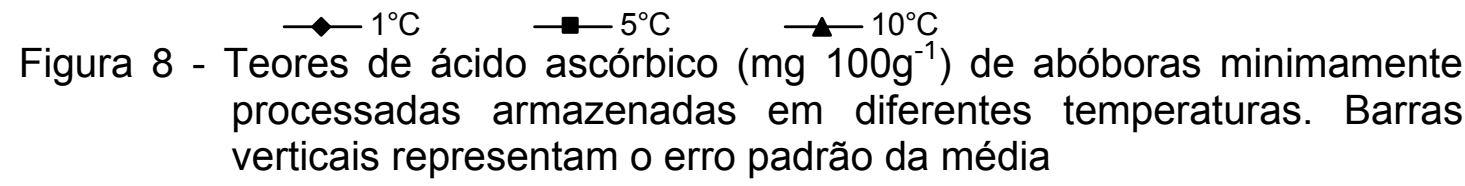

Observou-se uma maior redução nos teores de ácido ascórbico após o terceiro dia de armazenamento, essa redução foi mais significativa nas abóboras armazenadas a $10^{\circ} \mathrm{C}$ chegando a $47,34 \%$ de perdas, enquanto que a redução a 1 e $5^{\circ} \mathrm{C}$ foi de 21,21 e $38,52 \%$, respectivamente, aos 12 dias de armazenamento.

Zepplin \& Elvehjein (1944) citados por Lee \& Kader (2000) observaram que folhas de diferentes vegetais mantidos a $6^{\circ} \mathrm{C}$ perderam $10 \%$ dos teores de ácido ascórbico em 6 dias, enquanto que as mesmas quando armazenadas à temperatura ambiente tivera redução de $20 \%$ nos teores de ácido ascórbico.

\section{Carotenóides totais}

Pode-se observar na Figura 9 que, independentemente da temperatura, houve uma grande redução nos teores de carotenóides totais do dia do processamento (dia 0) para o $3^{\circ}$ dia de armazenamento chegando a $24,81 \%$, $33,50 \%$ e $36,42 \%$, para 1,5 e $10^{\circ} \mathrm{C}$, respectivamente. Após o $3^{\circ}$ dia os valores tenderam a aumentar sendo mais evidentes nas temperaturas de $1^{\circ} \mathrm{C}$ e $5^{\circ} \mathrm{C} . \mathrm{Na}$ temperatura de $10^{\circ} \mathrm{C}$ houve um aumento no $6^{\circ}$ dia de armazenamento, após 
este dia os valores tenderam a ficar constantes, em por volta de $100 \mu \mathrm{g}$ de carotenóides totais/g, até o final do período de armazenamento.

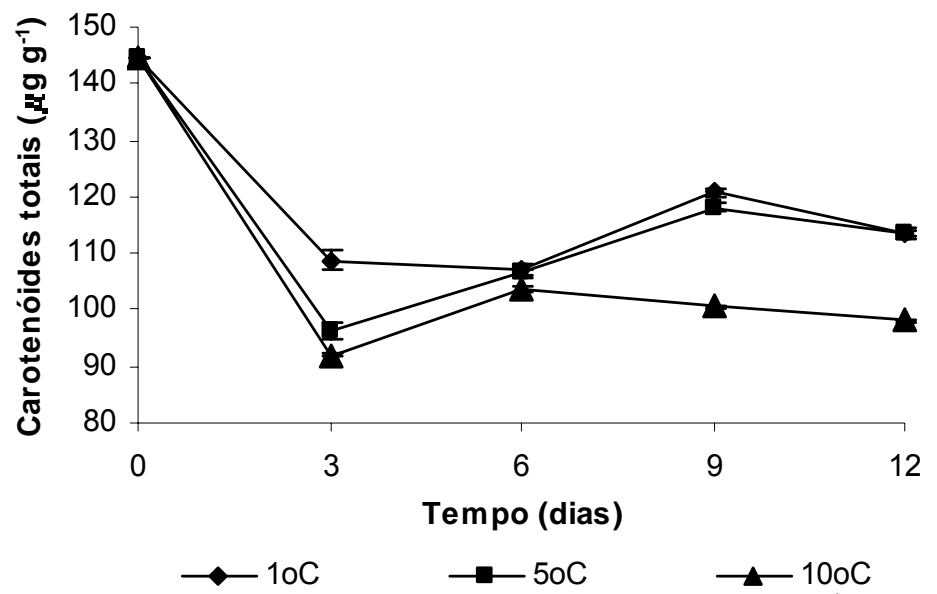

Figura 9 - Teores de carotenóides totais $\left(\mu \mathrm{g} \mathrm{g} \mathrm{g}^{-1}\right)$ de abóboras minimamente processadas armazenadas sob diferentes temperaturas. Barras verticais representam erro padrão da média

A coloração alaranjada da polpa das abóboras é devido à presença dos compostos chamados carotenóides. Segundo Rodriguez-Amaya (2001) os principais carotenóides encontrados nas abóboras (Cucurbita moschata Duch.) são o $\alpha$-caroteno e o $\beta$-caroteno, dentre outros. Os carotenóides são susceptíveis à isomerização e oxidação durante o processamento e armazenamento, as conseqüências práticas disso são a perda da cor, a redução da atividade biológica e a formação de compostos voláteis que proporcionam aromas desejáveis ou indesejáveis aos alimentos. A oxidação dos carotenóides depende de vários fatores como a presença de oxigênio, metais, enzimas, lipídeos insaturados, prooxidantes ou antioxidantes; exposição à luz; tipo e o estado físico dos carotenóides; e a temperatura e condições de armazenamento, entre outros fatores (Rodriguez-Amaya, 2001). Dessa forma a redução nos teores de carotenóides totais pode interferi na coloração das abóboras. 


\section{Coloração}

O armazenamento a $10^{\circ} \mathrm{C}$ causou esbranquiçamento das abóboras, o que pode ser verificado pelo aumento nos valores de luminosidade ao longo do período de armazenamento, partido do valor de 62,68 (no dia 0) e chegando 68,28 no último dia de armazenamento (Figura 10).

Processo semelhante ocorre em cenouras minimamente processadas, sendo denominado "white blush" (Lana, 2000). Para alguns grupos de pesquisadores esse esbranquiçamento é resultado da desidratação das células superficiais, devido aos danos causados pelo processamento (Tatsumi el al., 1993; Avena-Bustillos et al., 1994). Porém, para outros grupos é devido à formação de lignina na superfície dos cortes (Bolin \& Huxsoll, 1991). Existe ainda um terceiro grupo que acredita que o esbranquiçamento seja causado pela combinação dos dois processos, a desidratação e a formação de lignina (Cisneros-Zevallos et al., 1995).

Provavelmente o que esteja ocorrendo com as abóboras minimamente processadas armazenadas a $10^{\circ} \mathrm{C}$ seja, principalmente, desidratação, pois como pode ser observado na Figura 4 as abóboras armazenadas nessa temperatura tiveram uma maior perda de massa. As abóboras armazenadas a $1^{\circ} \mathrm{C}$ e $5^{\circ} \mathrm{C}$ não apresentaram diferença significativa entre si, ao longo do período de armazenamento, para a variável luminosidade. Seus valores tenderam de ficar constantes até o $9^{\circ}$ dia, após este dia houve um leve aumento dos valores. 


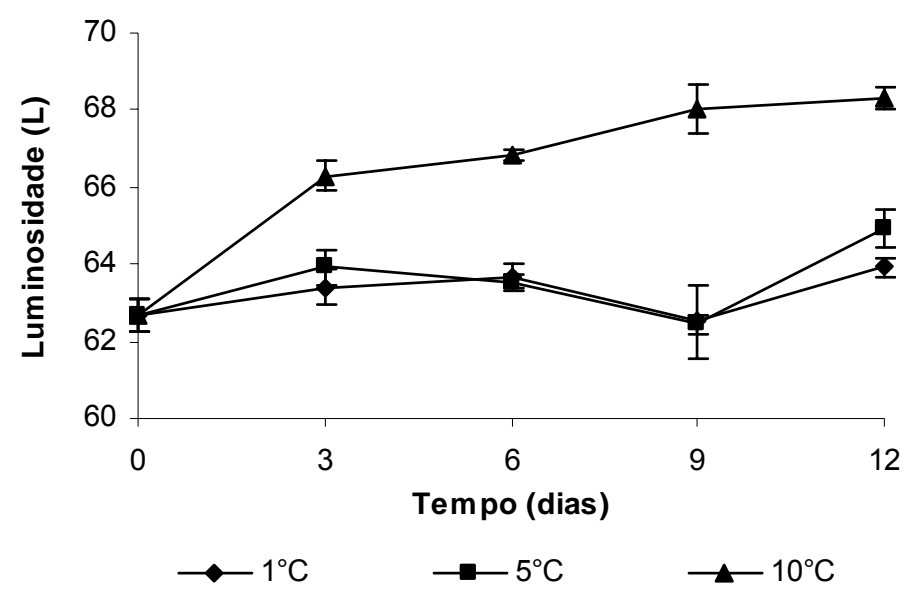

Figura 10 - Valores de luminosidade $(\mathrm{L})$ de abóboras minimamente processadas armazenadas sob diferentes temperaturas. Barras verticais representam erro padrão da média

As abóboras armazenadas a $1^{\circ} \mathrm{C}$ mantiveram valores de Chromaticidade $\left(\mathrm{C}^{*}\right)$ praticamente constantes (entre 53 e 54) durante o período de armazenamento (Figura 11). Já as abóboras armazenadas a $10^{\circ} \mathrm{C}$ tiveram um decréscimo nos valores de $C^{*}$ durante o armazenamento partindo de 53,27, chegando a 45,81 . Isto mostra que as abóboras mantidas a $10^{\circ} \mathrm{C}$ tenderam a perder a intensidade de cor. As abóboras armazenadas a $5^{\circ} \mathrm{C}$ tiveram um decréscimo nos valor de $\mathrm{C}^{*}$ no $3^{\circ} \mathrm{dia}$, mas sofreu aumento nos dois dias de análise subseqüentes, voltando a reduzir seu valor no último dia de análise.

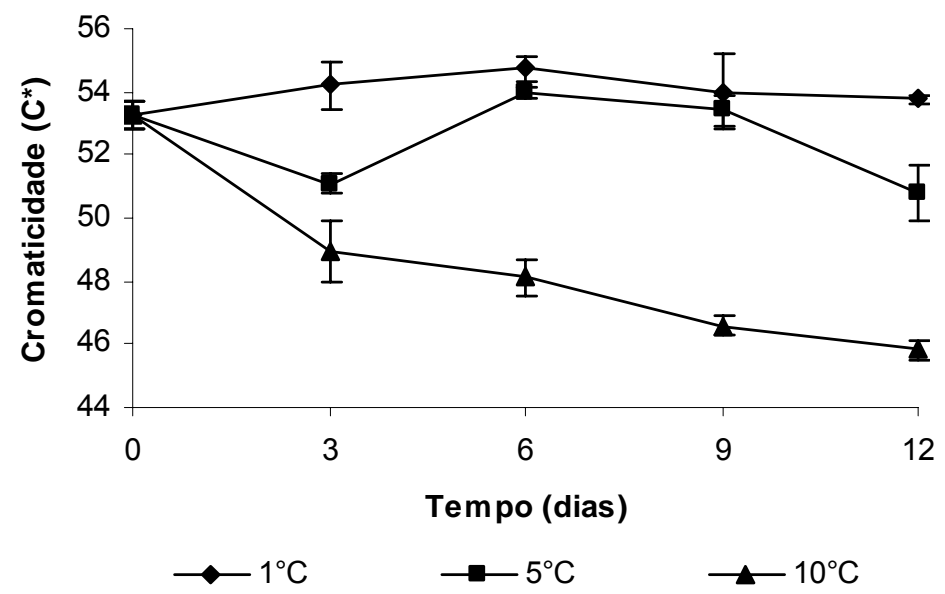

Figura 11 - Valores de cromaticidade $\left(C^{*}\right)$ de abóboras minimamente processadas armazenadas sob diferentes temperaturas. Barras verticais representam o erro padrão da média 
O ângulo de cor $\left(\mathrm{h}^{\circ}\right)$ não mostrou diferença entre os tratamentos nos dias de análises e se mostrou relativamente constante durante o armazenamento (Figura 12).

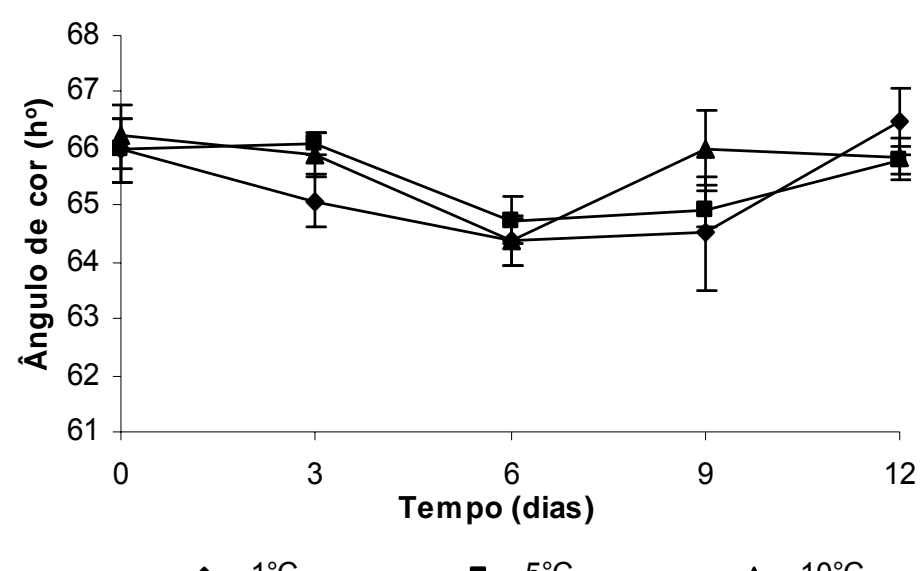

Figura 12 - Valores de ângulo de cor $\left(h^{\circ}\right)$ de abóboras minimamente processadas armazenadas sob diferentes temperaturas. Barras verticais representam erro padrão da média

A coloração é um dos principais parâmetros de qualidade, pois os consumidores já desenvolveram uma relação entre a cor e a qualidade máxima do produto (Kays, 1991). O uso de baixas temperaturas de armazenamento para os produtos minimamente processados reduzem a degradação da coloração dos tecidos vegetais lesionados (Wiley, 1997). No caso de abóboras a cor laranja é atribuída a qualidade do produto, quanto mais intensa essa cor maior é qualidade atribuída pelo consumidor.

\section{Análises microbiológicas}

Como não existe uma legislação específica no país, para produtos minimamente processados, utilizou-se os parâmetros apresentados por Morton (2001), que permite a comercialização de vegetais congelados e similares com contagem total de bactérias aeróbicas mesófilas de até $10^{5}-10^{6}$ UFC/g.

O crescimento da população de bactérias psicrotróficas foi retardado pela redução da temperatura de armazenamento (Tabela 1). As abóboras armazenadas a $1^{\circ} \mathrm{C}$ mantiveram a contagem total de bactérias psicrotróficas 


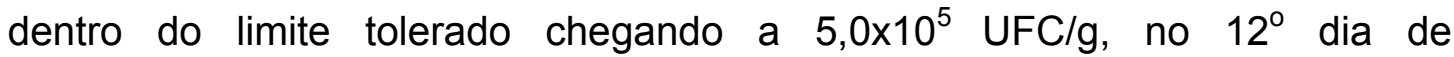
armazenamento, limite inferior preconizado por Morton (2001). Na temperatura de $5^{\circ} \mathrm{C}$ as abóboras apresentaram contagem de $4,0 \times 10^{5} \mathrm{UFC} / \mathrm{g}$ já no $6^{\circ}$ dia de armazenamento, e contagem de $8,0 \times 10^{6} \mathrm{UFC} / \mathrm{g}$ no $12^{\circ}$ dia de armazenamento. Embora ainda esteja dentro do limites aceitos, a recomendação para consumo deste produto, com tal contagem fica muito arriscada, pois a probabilidade de haver um microrganismo patógeno é maior. As abóboras mantidas a $10^{\circ} \mathrm{C}$ apresentaram contagem de $4,5 \times 10^{6} \mathrm{UFC} / \mathrm{g}$ no $6^{\circ}$ dia de armazenamento, e contagem de $7,2 \times 10^{7} \mathrm{UFC} / \mathrm{g}$ no $12^{\circ}$ dia de armazenamento, contagem muito elevada que torna o produto impróprio para o consumo.

Piagentini et al. (1997) verificaram um aumento na população de microrganismos psicrotróficos em repolho minimamente processado, de $10^{2}$ para $10^{5} \mathrm{UFC} / \mathrm{g}$, após quatro dias de armazenamento a $4^{\circ} \mathrm{C}$. García-Gimeno \& Zurera-Cosano (1997) notaram um aumento de $10^{5}$ para $10^{7} \mathrm{UFC/g}$ na contagem de microrganismos psicrotróficos em amostras de saladas de hortaliças minimamente processadas armazenadas a $4^{\circ} \mathrm{C}$.

Izumi \& Watada (1994) estudaram o crescimento microbiano em cenouras minimamente processadas armazenadas nas temperaturas de 0, $5 \mathrm{e}$ $10^{\circ} \mathrm{C}$, conservadas durante 28,21 e 11 dias, respectivamente. Os autores notaram que a contagem microbiológica total foi maior para a temperatura mais alta. Após 15 dias o produto estava com uma população de bactérias mesófilas totais de 7,0 log UFC g ${ }^{-1}$ a $0^{\circ} \mathrm{C}$ e acima de $8,01 \log$ UFC g ${ }^{-1}$ a $5^{\circ} \mathrm{C}$. As cenouras armazenadas a $10^{\circ} \mathrm{C}$ estavam com uma contagem de 8,01 log UFC g ${ }^{-1}$, já no 11 dia de armazenamento.

Habibunnisa et al. (2001) verificaram uma contagem bactérias aeróbicas mesófilas de $32,4 \times 10^{4} \mathrm{UFC} / \mathrm{g}$, no $25^{\circ}$ dia, em abóboras do tipo moranga, minimamente processadas, armazenadas a $5^{\circ} \mathrm{C}$.

A temperatura de armazenamento é, provavelmente, o fator mais importante que afeta o crescimento dos microrganismos nos produtos 
minimamente processados (Brackett, 1987; King Jr. \& Bolin, 1989; Nguye-the \& Carlin, 1994).

Embora não existam, na legislação brasileira vigente, padrões para bactérias psicrotróficas totais e coliformes totais, no que diz respeito à quantidade de microrganismos presentes em um alimento, pose-se afirmar que quantidades elevadas (> $10^{5}-10^{6} \mathrm{UFC} / \mathrm{g}$ ) são completamente indesejáveis, pelo menos pelas seguintes razões: risco do alimento estar estragado, perda real ou potencial das qualidades organolépticas, comprometimento da aparência do alimento. Quanto maior o número de microrganismos em um alimento, maiores soa as probabilidades de presença de patógenos e/ou deterioradores (Caruso \& Camargo, 1984).

Tabela 1. Contagem total de bactérias psicrotróficas, em abóboras minimamente processadas armazenadas em diferentes temperaturas, utilizando-se a metodologia convencional (PCA)

\section{Temperaturas} Dias após corte

\begin{tabular}{llll} 
& $\mathbf{0}$ & $\mathbf{6}$ & $\mathbf{1 2}$ \\
\hline $1^{\circ} \mathrm{C}$ & $5,0 \times 10$ & $8,0 \times 10^{3}$ & $5,0 \times 10^{5}$ \\
$5^{\circ} \mathrm{C}$ & $6,0 \times 10$ & $4,0 \times 10^{5}$ & $8,0 \times 10^{6}$ \\
$10^{\circ} \mathrm{C}$ & $4,0 \times 10$ & $4,5 \times 10^{6}$ & $7,2 \times 10^{7}$ \\
\hline
\end{tabular}

Os resultados obtidos representam a média aritmética das UFC (unidades formadoras de colônia)/g de produto.

Não foi detectada presença de Salmonella, bem como o crescimento de coliformes totais e coliformes a $45^{\circ} \mathrm{C}$ em nenhuma das temperaturas de armazenamento, durante o período analisado.

Ainda não existe uma legislação específica para frutas e hortaliças minimamente processadas. Entretanto, estes resultados estão dentro do limite estabelecido pela resolução RDC n¹2 de 02 de janeiro de 2001 da Agência Nacional de Vigilância Sanitária (ANVISA) do Ministério de Saúde, que estabelece a ausência de Salmonella (em $25 \mathrm{~g}$ de produto) e permite um 
máximo de $10^{2} \mathrm{NMP}$ de coliformes a $45^{\circ} \mathrm{C} / \mathrm{g}$, em hortaliças in natura, visando a preservação da saúde pública.

No $9^{\circ}$ dia de armazenamento as abóboras mantidas a $10^{\circ} \mathrm{C}$ apresentaram sinais deterioração por fungos e bactérias (Figura 13).

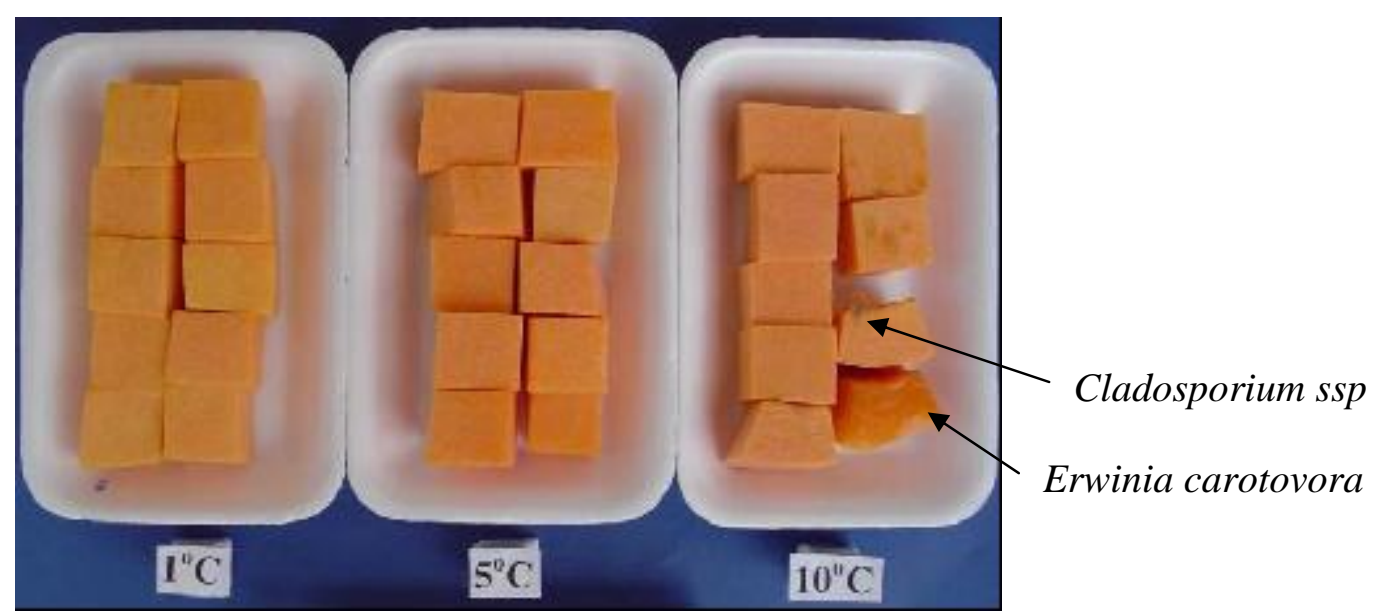

Figura 13 - Abóboras minimamente processadas com 9 dias de armazenamento

Estes resultados indicam a eficiência dos cuidados higiênicos tomados durante o processamento, e que o processo de sanitização pode ter eliminado estes patógenos.

Segundo Wiley (1997), a qualidade microbiológica é um dos fatores mais importantes na qualidade de frutas e hortaliças minimamente processadas e refrigeradas, pois os microrganismos podem afetar de forma adversa tanto a qualidade sensorial como a segurança destes produtos.

A temperatura de armazenamento tem efeitos significativos nos processos fisiológicos e qualitativos de abóboras minimamente processadas. Observou-se que a $10^{\circ} \mathrm{C}$ as abóboras apresentaram maiores taxas respiratórias e de produção de etileno, em relação às temperaturas de $1^{\circ} \mathrm{C}$ e $5^{\circ} \mathrm{C}$, tendo como conseqüência a redução dos teores de sólidos solúveis. Além disso, como o metabolismo das abóboras à $10^{\circ} \mathrm{C}$ foi mais intenso, houve um consumo maior de sustâncias antioxidativas como o ácido ascórbico e os carotenóides totais, reduzindo a qualidade nutricional do alimento. Nas temperaturas de $1^{\circ} \mathrm{C}$ 
e $5^{\circ} \mathrm{C}$ as abóboras apresentaram comportamentos semelhantes entre si, exceto quanto à produção de etileno, onde não pôde ser detectada a produção do mesmo a $1^{\circ} \mathrm{C}$.

As análises microbiológicas, principalmente a contagem de bactérias psicrotróficas, mostrou a grande importância de se manter uma cadeia de frio durante todo o processamento e comercialização do produto. Como não foram observadas presenças de coliformes totais, coliformes a $45^{\circ} \mathrm{C}$ e Salmonella nas amostras analisadas, ficou evidenciado a eficácia dos cuidados higiênicosanitários tomados durante as etapas do processamento do produto, adequando-o nos padrões microbiológicos vigentes no país.

\subsection{Conclusões}

- A temperatura de $10^{\circ} \mathrm{C}$ causou aumento da taxa respiratória, produção de etileno e perda de massa, redução dos teores de sólidos solúveis, ácido ascórbico e carotenóides totais, além de propiciar maior desenvolvimento de bactérias pscicrotróficas. Fator importante para escolha da temperatura de armazenamento.

- Temperatura de $1^{\circ} \mathrm{C}$ foi a que apresentou menor taxa respiratória e produção de etileno, menores perdas nos teores de sólidos solúveis, ácido ascórbico e carotenóides totais. O crescimento de bactérias pscicrotróficas se apresentou dentro do limite permitido, ficando 2 ciclos logarítmicos abaixo da contagem de $10^{\circ} \mathrm{C}$.

- A temperatura de $5^{\circ} \mathrm{C}$ teve comportamento semelhante a $1^{\circ} \mathrm{C}$, porém seus valores para todas as análises ficaram intermediários entre os valores de $1^{\circ} \mathrm{C}$ e $10^{\circ} \mathrm{C}$, tendo seu valores mais próximos dos valores da temperatura mais baixa. 


\section{ALTERAÇÕES FISIOLÓGICAS, QUALITATIVAS E MICROBIOLÓGICAS DURANTE O ARMAZENAMENTO DE ABÓBORA MINIMAMENTE PROCESSADA EM DIFERENTES TIPOS DE CORTE}

\section{Resumo}

O presente estudo teve como objetivo verificar as alterações fisiológicas, qualitativas e microbiológicas de abóboras minimamente processadas submetidas aos cortes em meia-rodela, cubos e retalhos, e armazenadas em a $5^{\circ} \mathrm{C}$ e $85-90 \%$ de UR durante 12 dias. A taxa respiratória dos três tipos de corte apresentaram valores entre 3,2 e $7,5 \mathrm{~mL} \mathrm{CO}_{2} \mathrm{~kg}^{-1} \mathrm{~h}^{-1}$. Os cortes em cubos e retalhos apresentaram maiores taxas de produção de etileno, atingindo valores de $4,05 \mu \mathrm{L} \mathrm{C}_{2} \mathrm{H}_{4} \mathrm{~kg}^{-1} \mathrm{~h}^{-1}$ e $3,82 \mu \mathrm{L} \mathrm{C}_{2} \mathrm{H}_{4} \mathrm{~kg}^{-1} \mathrm{~h}^{-1}$, respectivamente. O corte em retalhos apresentou alterações qualitativas indesejáveis, como maior perda de massa $(2,66 \%)$, maiores reduções nos teores de sólidos solúveis, de ácido ascórbico e de carotenóides, além de propiciar maior crescimento de bactérias pscicrotróficas. Os cortes em cubos e meia-rodela apresentaram comportamento semelhante e valores próximos para a maioria das variáveis físicas, químicas e físico-químicas analisadas e, também, para contagens de bactérias psicrotróficas. Foi verificada ausência de coliformes totais, coliformes a $45^{\circ} \mathrm{C}$ e Salmonella, para os três tipos de corte durante o armazenamento.

Palavra-chave: Cucurbita moschata Duch., processamento mínimo, carotenóides, respiração, etileno, microbiologia. 
4 PHYSIOLOGICAL, QUALITATIVE AND MICROBIOLOGICAL CHANGES IN MINIMALLY PROCESSED SQUASH SUBMITTED TO DIFFERENT CUT TYPES

\section{Summary}

The present work was carried out with the objective of determinate the physiological, qualitative and microbiological alterations of minimally processed squash submitted to different cut types. The cut used were middle-circle, cube and shred. The product was stored at $5^{\circ} \mathrm{C}$ and $85-90 \% \mathrm{RH}$ during 12 days. The three cuts showed respiratory rate from 3,2 to $7,5 \mathrm{~mL} \mathrm{CO} \mathrm{kg}^{-1} \mathrm{~h}^{-1}$. The cut in cube and shred showed higher ethylene production $\left(4,05\right.$ and $3,82 \mu \mathrm{L} \mathrm{C}_{2} \mathrm{H}_{4} \mathrm{Kg}^{-1}$ $\mathrm{h}^{-1}$, respectively). The shredded squash showed undesired qualitative alterations as higher weight loss $(2,66 \%)$, decrease in soluble solids amount, acid ascorbic and carotenoids. Beside, this cut increase growth of psychrotrophic bacteria. The cube and middle-circle cut have presented similar behavior in relation to the physical, chemical and physicochemical analysis and psychrotrophic bacteria amount. It was no showed total coliform, coliforms at $45^{\circ} \mathrm{C}$ and Salmonella in the cut types during storage.

Key-words: Cucurbita moschata Duch., ascorbic acid, carotenois, respiration, ethylene, microbiology.

\subsection{Introdução}

Os produtos minimamente processados são o segmento que mais cresce dentro do mercado varejista de alimentos. No entanto, o processamento mínimo ainda necessita de muitos estudos devido às dificuldades de manter uma boa qualidade durante períodos prolongados (Soliva-Fortuny \& Martin-Belloso, 2003). O processamento mínimo de hortaliças compreende as operações que 
eliminam as partes não comestíveis, como cascas, talos e sementes, seguidas pelo corte em tamanhos menores, tornado-a prontas para o consumo imediato e mantendo sua condição de produto in natura (Lana, 2000).

A fisiologia das frutas e hortaliças minimamente processadas correspondente à a fisiologia de tecidos injuriados ou submetidos a estresses. Estes produtos são mais perecíveis do que quando intactos, considerando que são submetidos a severos estresses físicos, advindos, principalmente, do descascamento e do corte (Brecht, 1995). O efeito dos cortes ou injúrias provoca o rompimento de organelas, modifica a permeabilidade de célula, provoca uma desorganização celular, ativando a síntese de etileno e aumentando a respiração. No momento do corte, os ácidos graxos livres (poliinsaturados) reagem com $\mathrm{O}_{2}$ por meio da lipoxigenase, formando hidroperóxidos que levam à perda do valor nutritivo e causam alterações indesejáveis no sabor e no aroma (Durigan \& Cassaro, 2000). O etileno proveniente do corte ("etileno de ferida") contribui para a biossíntese de enzimas envolvidas em alterações fisiológicas e bioquímicas associadas à senescência (Brecht, 1995). Além disso o exudato celular extravasado na superfície de corte é um meio favorável para o crescimento de fungos e bactérias (Burns, 1995)

A injúria mecânica causada pelo corte ou descascamento é um dos maiores obstáculos para a conservação dos produtos minimamente processados, sendo que a taxa respiratória desses produtos é muitas vezes superior que a de produtos intactos (Cantwell, 1992).

Com o objetivo de ampliar o conhecimento e atender as novas demandas do mercado por produtos minimamente processados, este trabalho se propôs a estudar as alterações decorrentes dos diferentes tipos de corte visando obter aquele que promova melhor manutenção da qualidade e maior tempo de conservação de abóbora minimamente processada. 


\subsection{Material e Métodos}

As abóboras maduras (Cucurbita moschata Duch.), cv. Canhão, forma adquiridas de um produtor da região de Tupã-SP e trazidas ao Laboratório de Pós-Colheita do Departamento de Produção Vegetal, da ESALQ/USP.

Antes de serem trazidas ao laboratório, as abóboras sofreram uma préseleção, sendo escolhidos os frutos sem injúrias e uniformes quanto ao tamanho, cor da casca e formato. Ao chegarem ao laboratório os frutos foram lavados com detergente e em água corrente, para retirada da sujeira grosseira. Em seguida, as abóboras sofreram uma desinfecção inicial com imersão em solução contento $200 p p m$ de cloro ativo. Após a etapa de desinfecção as abóboras foram colocadas em câmara fria a $10 \pm 1^{\circ} \mathrm{C}$ com $85-90 \%$ UR, onde permaneceram por 16 horas.

O processamento foi realizado em câmara fria a $10 \pm 1^{\circ} \mathrm{C}$, utilizando-se roupas apropriadas (botas, avental, touca, máscara e luvas). A água de processamento foi destilada e refrigerada a $5^{\circ} \mathrm{C}$.

A primeira etapa do processamento consistiu em corte em rodelas de $3,0 \mathrm{~cm}$ de espessura, utilizando-se faca de inoxidável afiada; remoção das sementes e parte esponjosa (com auxílio de colher) e cortes finais. Após os cortes, os pedaços foram lavados em água destilada (para retira de excesso de suco celular), sanitizados com solução de cloro ativo a $200 p p m$ utilizando o Dicloro-S- Triazinatriona Sódica Diidratada (SUMAVEG ${ }^{\circledR}$ ) e enxaguados com água destilada contendo 3ppm de cloro ativo. Em seguida, os pedaços fora deixados em escorredores doméstico para retirada do excesso de água, com exceção dos retalhos que foram centrifugados em centrífuga adaptada (ARNO), durante 1 minuto. Os pedaços foram pesados $(300 \mathrm{~g})$ e acondicionados em

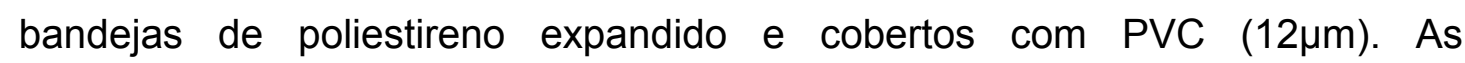
embalagens foram armazenadas a $5 \pm 1^{\circ} \mathrm{C}$ e $85-90 \%$ UR. 


\section{Tratamentos}

Os tipos cortes testados foram:

a) Meia-rodela, corte obtido através da secção ao meio das rodelas iniciais;

b) Cubos, com arestas de 3,0 x 3,0 x 3,0cm;

c) Retalhos, obtidos utilizando-se uma processadora industrial (Robot Coupe), com disco de corte de $7 \mathrm{~mm}$ de espessura (Figura 1).

O armazenamento foi por período de 12 dias, sendo feitas análises nos dias $0,3,6,9$ e 12, para as avaliações físico-químicas e análises no $0,6^{\circ}$ e $12^{\circ}$ dias de armazenamento, para as avaliações microbiológicas.

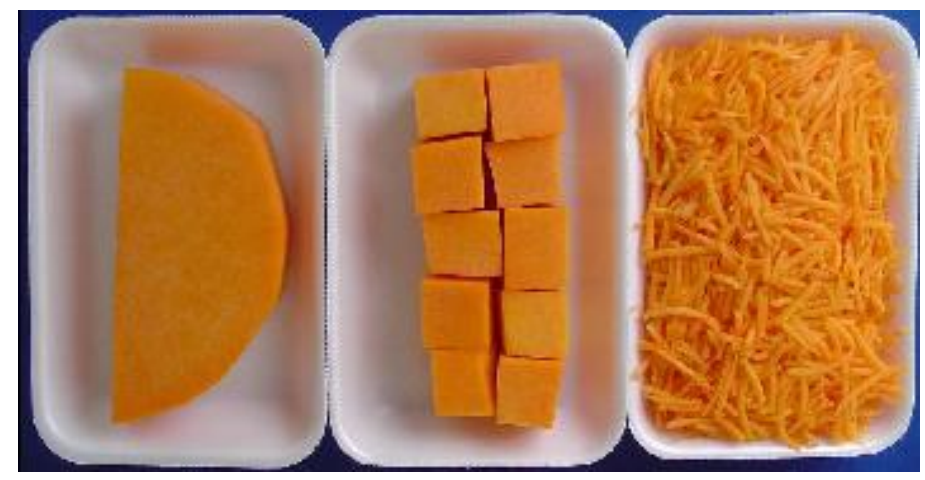

Figura 1 - Tipos de corte das abóboras minimamente processadas. Da esquerda para a direita, corte em meia-rodela, cubos e retalhos

\section{Análises físicas, químicas e físico-químicas}

As determinações realizadas foram: a) Taxa respiratória: $150 \mathrm{~g}, 150 \mathrm{~g}$ e $300 \mathrm{~g}$ de abóbora minimamente processada foram colocadas em frascos de vidro de capacidade de $600 \mathrm{~mL}, 600 \mathrm{~mL}$ e $1500 \mathrm{~mL}$, para os cortes em retalhos, cubos e meia-rodela, respectivamente, fazendo-se leituras em cromatógrafo a gás, resultados foram expressos em $\mathrm{mL} \mathrm{CO}_{2} \mathrm{Kg}^{-1} \mathrm{~h}^{-1}$; b) Taxa de produção de etileno, utilizando o mesmo procedimento da análise da taxa respiratória, sendo os resultados expressos em $\mu \mathrm{L} \mathrm{C}_{2} \mathrm{H}_{4} \mathrm{Kg}^{-1} \mathrm{~h}^{-1}$; c) Perda de massa (\%), através da diferença entre a massa inicial e final da repetição; d) Coloração ( $\left.L, C^{*} e h^{\circ}\right)$, 
com auxílio de colorímetro Minolta; e) Teor de sólido solúveis ( $\left.{ }^{\circ} B r i x\right)$, utilizando um refratômetro (Atago); f) Acidez titulável (\%), através de titulação com $\mathrm{NaOH}$ $0,1 \mathrm{~N} ; \mathrm{g})$ Teor de ácido ascórbico, obtida através de titulação com DCFI, com resultados expresso em $\mathrm{mg}^{100 \mathrm{~g}^{-1}}$; h) Teor de carotenóides totais $\left(\mu \mathrm{g} \mathrm{g}^{-1}\right.$ ), com auxílio de espectrofotômetro (FEMTO-700 Plus).

Maiores detalhes sobre as análises podem ser encontradas no capítulo 3 , nas páginas 22 a 25 .

\section{Análises microbiológicas}

As análises microbiológicas realizadas foram: contagem de bactérias psicrotróficas (UFC/g), pelo método do plaqueamento em profundidade com diluições de $10^{-1}$ a $10^{-3}$; contagem de coliformes fecais (NMP), pela técnica de Tubos Múltiplos, utilizando as diluições de $10^{-1}$ a $10^{-3}$; e detecção de Salmonella (ausência ou presença), com auxílio de kits ('1-2 Test' - Biocontrol/USA).

Detalhes sobre as análises realizadas podem ser encontrados no capítulo 3, nas páginas de 22 a 25 .

\section{Delineamento experimental}

O delineamento experimental utilizado foi inteiramente casualizado com esquema fatorial $3 \times 5$. Os fatores estudados foram tipos de corte (meia-rodela, cubos e retalhos) e tempo de armazenamento (0, 3, 6, 9 e 12 dias). Foram utilizadas quatro repetições por tratamento, sendo cada repetição composta de uma bandeja com $300 \mathrm{~g}$ de abóbora minimamente processada. Para a caracterização do lote experimental (tempo zero), quatro amostras foram analisadas logo após o processamento mínimo do produto. Os resultados obtidos das análises físicas químicas e físico-químicas foram submetidos à análise do erro padrão. As diferenças entre dois tratamentos maior que a soma dos erros padrões foram consideradas significativas $(P<0,05)$ (Moretti et al., 2002). Para avaliação dos aspectos microbiológicos os resultados foram 
expressos em UFC/g de produto para bactérias psicrotróficas, NMP/g para coliformes totais e presença ou ausência de Salmonella em $25 \mathrm{~g}$ de produto.

\subsection{Resultados e Discussão}

\section{Taxa respiratória}

Houve um decréscimo da taxa respiratória durante as primeiras 4 horas após o processamento, independentemente do tipo de corte. Embora o corte em meia-rodela seja o que sofreu menor injúria, este apresentou valores superiores, comparado aos cortes em cubos e retalhos (Figura 2).

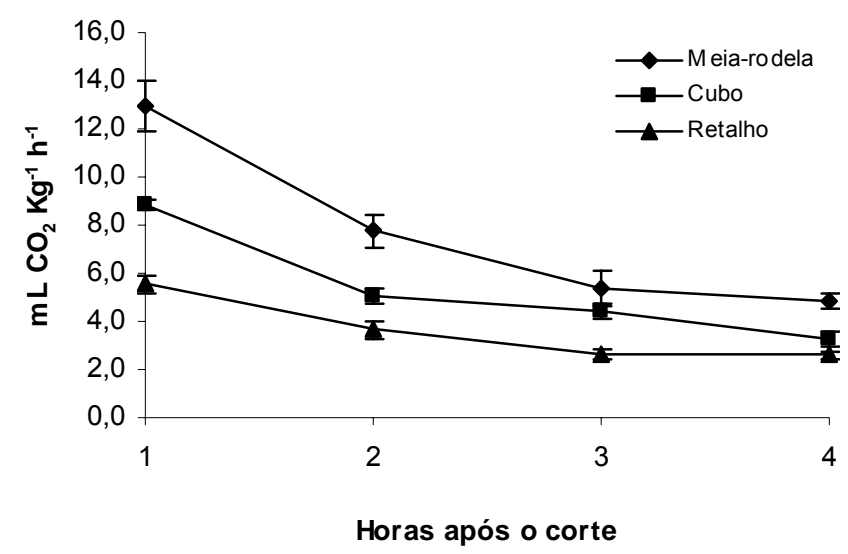

Figura 2 - Taxa respiratória, logo após o corte, de abóboras minimamente submetidas a diferentes tipos de corte e armazenadas a $5^{\circ} \mathrm{C}$. Barras verticais representam o erro padrão da média

Porte \& Maia (2001) afirmam que os tecidos fatiados, cuja superfície de exposição é maior, apresentam maior taxa de respiração, porém isso não foi notado no presente trabalho. Até o $8^{\circ}$ dia de armazenamento as taxas respiratórias se mantiveram constantes em todos os tratamentos, não havendo diferença entre os mesmos. A partir do $9^{\circ}$ dia somente o corte em retalhos apresentou uma elevação na taxa respiratória atingindo valores de $42,46 \mathrm{~mL}$ $\mathrm{CO}_{2} \mathrm{Kg}^{-1} \mathrm{~h}^{-1}$ (Figura 3). 
O estresse causado pelo corte resulta em ativação metabólica com aumento da taxa respiratória, e em muitos casos, na produção de etileno (Varouquaux \& Wiley, 1997). Segundo Watada et al. (1990) estas alterações ocorrem porque as enzimas presentes no vacúolo entram em contanto com os substratos presentes no citoplasma da célula, devido à descompartimentação causada na célula pelo corte.

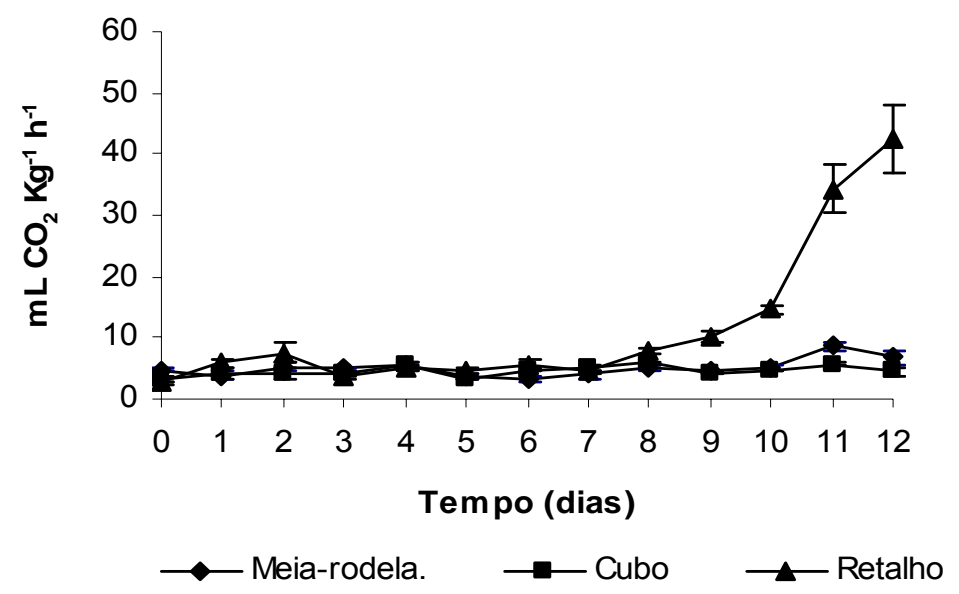

Figura 3 - Taxa respiratória de abóboras minimamente processadas submetidas a diferentes tipos de corte e armazenadas a $5^{\circ} \mathrm{C}$. Barras verticais representam o erro padrão da média

Talvez o fato das abóboras terem sido armazenadas sob refrigeração, na temperatura indicada como ideal por muitos autores, tenha diminuído os efeitos dos tipos de corte sobre taxa respiratória. Muitos autores afirmam que a temperatura exerce papel fundamental na respiração de vegetais, sendo que sua redução, também, reduz a taxa respiratória (Watada et al., 1990; Watada et al., 1996; Brecht, 1995; Sigrist, 1998; Porte \& Maia, 2001).

\section{Produção de Etileno}

O tipo de corte teve influência sobre a produção de etileno em abóboras minimamente processadas, sendo que os corte em cubos e retalhos produziram maiores quantidades de etileno, chegando a picos de até $4,05 \mu \mathrm{L} \mathrm{C}_{2} \mathrm{H}_{4} \mathrm{Kg}^{-1} \mathrm{~h}^{-1}$, nos cubos, e $3,82 \mu \mathrm{L} \quad \mathrm{C}_{2} \mathrm{H}_{4} \quad \mathrm{Kg}^{-1} \mathrm{~h}^{-1}$ nos retalhos, no $3^{\circ}$ e $4^{\circ}$ dias, 
respectivamente. Os cortes em cubo e meia-rodela apresentaram os picos de produção de etileno no $3^{\circ}$ dia de armazenamento, enquanto que o corte em retalho apresentou seu pico no $4^{\circ}$ dia (Figura 4).

O etileno produzido pelo corte ("etileno de ferida") pode aumentar a permeabilidade das membranas e reduzir a o biossíntese de fosfolipídeos, o qual pode prejudicar a integridade das membranas e o processo dinâmico das células (Watada et al., 1990), causando maior deterioração dos tecidos dos vegetais.

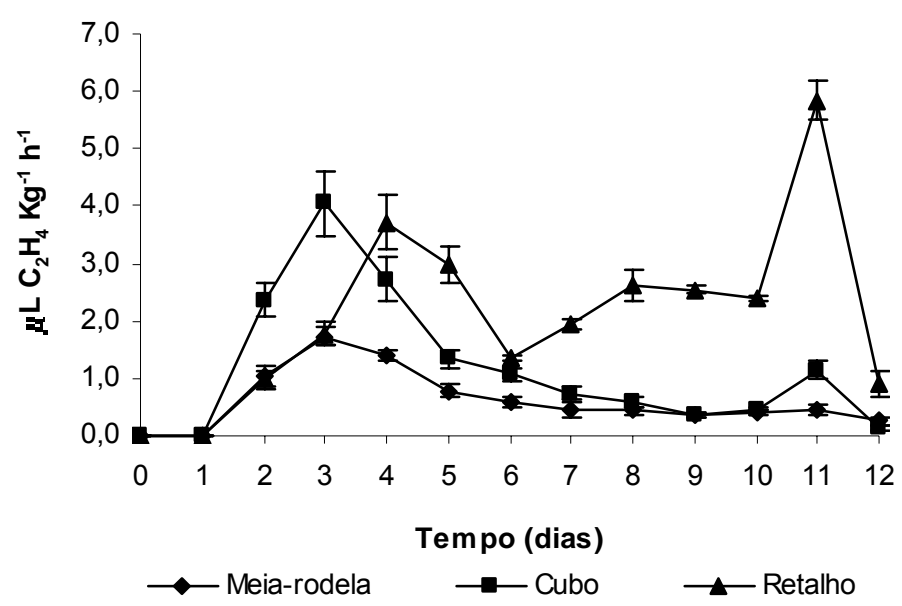

Figura 4 - Taxa de produção de etileno em abóboras minimamente processadas, submetidas a diferentes tipos de corte e armazenadas a $5^{\circ} \mathrm{C}$. Barras verticais representam o erro padrão da média

Nos tecidos de muitas plantas a produção de etileno se eleva com o aumento da severidade do corte, como por exemplo, em maçã, tomate e batata doce. Os níveis de ACC e atividade da ACC sintase aumentaram em tomates, abóboras do tipo morangas e melões da variedade Cantoloupe que sofreram ferimentos (Abeles et al., 1992).

Durigan \& Cassaro (2000) afirmam que a desorganização celular provocada pela corte ativa a produção de etileno aumentando a respiração. Nas abóboras minimamente processadas houve um aumento da produção de etileno (Figura 4), inclusive tendo relação com o tipo de corte, mas isto não 
refletiu num aumento da taxa respiratória, que só aumentou após 10 dias no corte em retalho (Figura 2).

\section{Perda de massa}

A perda de massa é o somatório da perda de água por transpiração e da perda de carbono através da respiração. Este processo ocorre durante todo período de armazenamento, sendo tanto maior quanto menor for o tamanho dos cortes (Izumi et al., 1996). Isto devido a maior área de exposição dos cortes em tamanhos menores. Assim, o corte em retalhos teve uma maior perda de massa, em relação aos cortes em meia-rodela e cubos (Figura 5).

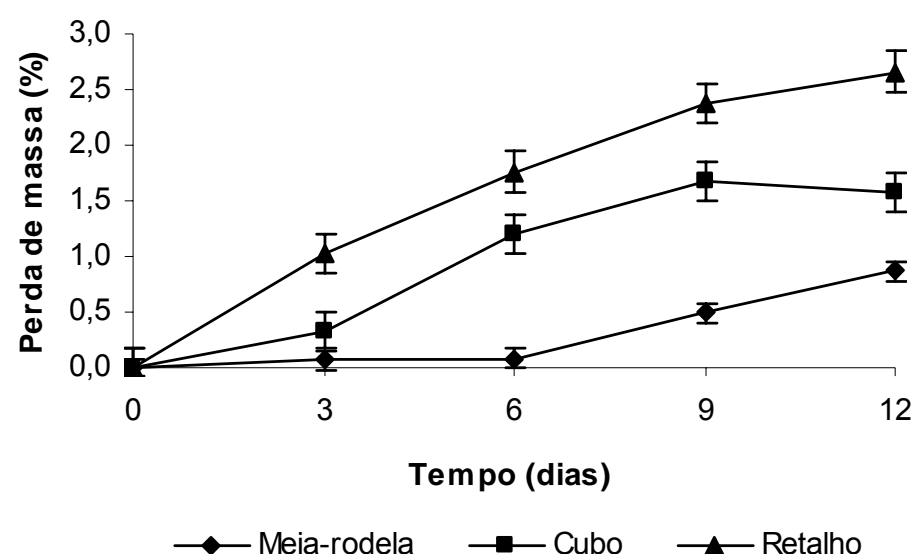

Figura 5 - Perda de massa (\%) de abóboras minimamente processadas submetidas a diferentes tipos de corte e armazenadas a $5 \pm 1^{\circ} \mathrm{C}$. Barras verticais representam o erro padrão da média

Embora os valores tenham ficado aquém daqueles citados por Finger \& Vieira (1997) de 5 a 10\% como críticos para as perdas de massa, as perdas foram de $0,87 \% ; 1,58 \%$ e $2,66 \%$ para os cortes em meia-rodela, cubo e retalho, respectivamente. O corte em meia-rodela apresentou menores perdas de massa durante todo período de armazenamento, sendo seguido pela corte em cubos e por último o corte em retalhos.

Pinto (2002) estudando diferentes tipos de corte em melancia 'Crimson Sweet', não observou diferenças entres as melancias fatiadas em relação aos cubos a $3^{\circ} \mathrm{C}$. Porém, a mesma autora quando estudou os tipos de corte em 
melões do tipo Orange Fresh notou que as fatias perderam mais massa que os cubos quando armazenados a $3^{\circ} \mathrm{C}$.

\section{Sólidos solúveis}

O corte em retalhos apresentou maior redução nos teores de sólidos solúveis, durante todo o período de armazenamento, mostrando reduções de até $2,45^{\circ}$ Brix entre o primeiro e o último dia. Isto ocorreu devido à maior intensidade de ferimentos provocados nesse tipo de corte tendo como conseqüência maior descopartimentação celular e maior extravasamento do suco celular.

O corte em cubos não apresentou variações nos teores de sólidos solúveis ficando em torno de $5,33^{\circ}$ Brix. Já o corte em meia-rodela apresentou um leve acréscimo nos teores de sólidos solúveis (Figura 6).

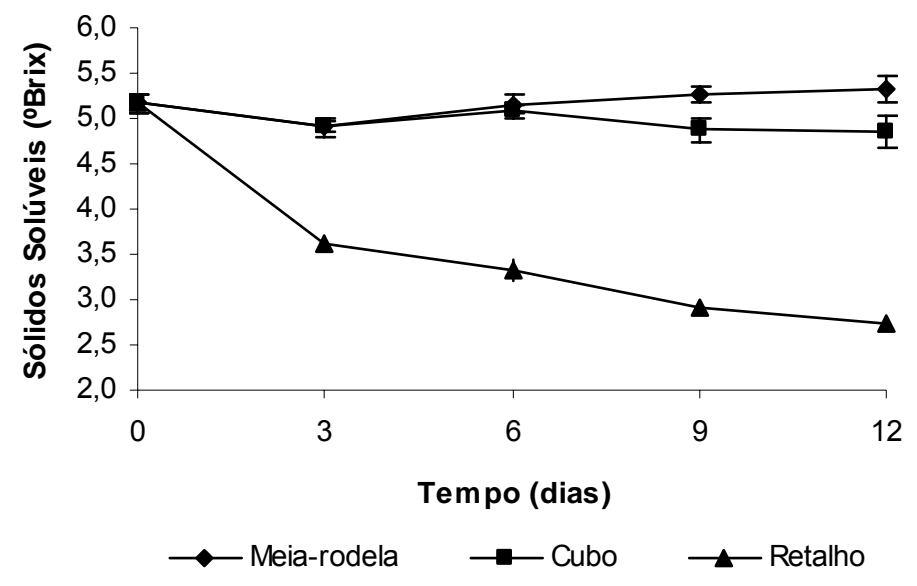

Figura 6 - Teores de sólidos solúveis ( ${ }^{\circ}$ Brix) de abóboras minimamente processadas submetidas a diferentes tipos de corte $e$ armazenadas a $5^{\circ} \mathrm{C}$. Barras verticais representam o erro padrão da média

Arruda et al. (2003a) estudando melão minimamente processado, observaram um aumento nos teores de sólidos solúveis de 0,68 e 0,16 ${ }^{\circ} \mathrm{Brix}$, durante o período de armazenamento, em melões cortados em fatias e cubos, respectivamente. Miranda (2001) afirma que esse acréscimo nos teores de 
sólidos solúveis ocorre devido ao estresse causado pelas etapas do processamento mínimo.

\section{Acidez titulável}

A concentração de ácidos orgânicos, expressa como acidez titulável, apresentou-se baixa e com variações pouco expressivas ao longo do período de armazenamento, exceto no corte em retalhos que apresentou um aumento nos valores de acidez total a partir do $6^{\circ}$ dia de armazenamento (Figura 7).

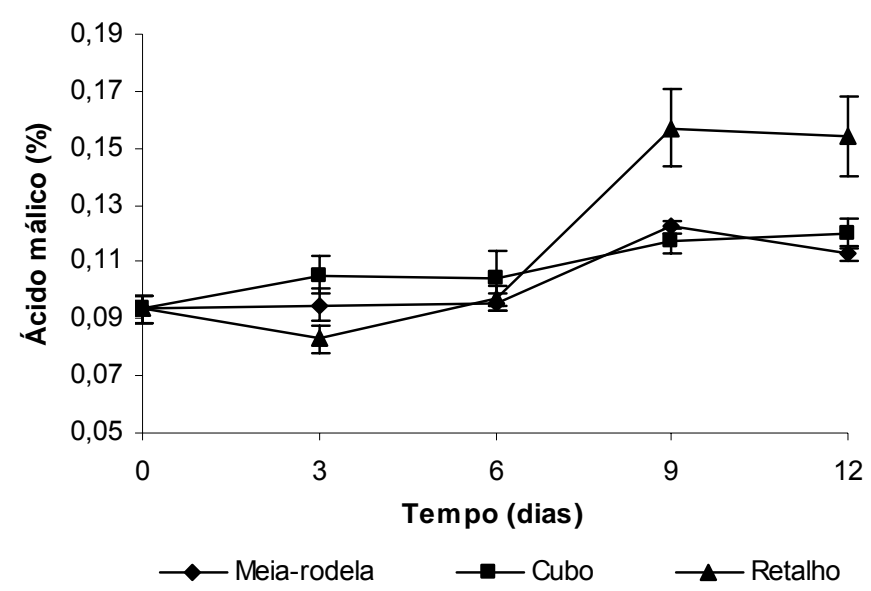

Figura 7 - Valores de acidez titulável (\% ácido málico) de abóboras minimamente processadas submetidas a diferentes tipos de corte e armazenadas a $5^{\circ} \mathrm{C}$. Barras verticais representam erro padrão da média

Os ácidos orgânicos podem ser encontrados em frutas e hortaliças de forma natural ou acumulados, em conseqüência do processo de fermentação ou por adição dos mesmos durante processamento (Wiley, 1997). O aumento da acidez, observado no presente trabalho, pode estar associado ao processo fermentativo conforme citado por Wiley (1997).

\section{Ácido ascórbico}

Como o corte em retalhos tende a aumentar a área de contato do da abóbora com fatores do ambiente como calor, luz e oxigênio, além de ocasionar maior descompartimentação celular, este teve uma maior perda nos teores de 
ácido ascórbico durante o período de armazenamento, sendo seguido do corte em cubos. Por possuir uma menor área de exposição ao ambiente, o corte em meia-rodela foi o que apresentou menores perdas de vitamina C (Figura 8).

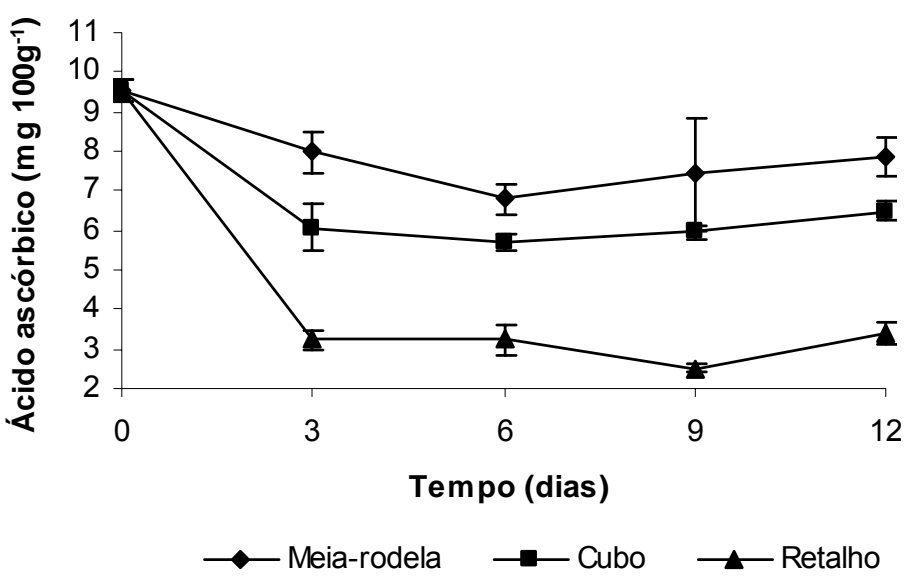

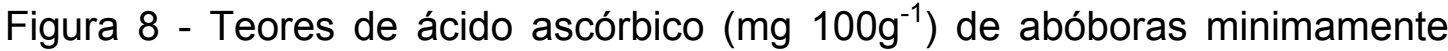
processadas submetidas a diferentes tipos de corte e armazenadas a $5^{\circ} \mathrm{C}$. Barras verticais representam erro padrão da média

Perdas de vitamina C ocorrem quando vegetais são severamente cortados ou picados, tal como repolho, alface, cenouras e outros vegetais que compõe mixers de saladas (Mozafar, 1994).

Segundo Lee \& Kader (2000), a retenção de vitamina C é afetada pelo tipo de corte utilizado no produto. Os autores verificaram que a retenção de vitamina $\mathrm{C}$ em alfaces cortadas em pequenos pedaços por máquinas foram 25$63 \%$ mais baixos do que as cortadas com as mãos.

A estabilidade das vitaminas nos alimentos é afetada por inúmeros fatores, incluindo calor, luz, oxigênio e $\mathrm{pH}$. O ácido ascórbico é um dos compostos vitamínicos que se degradam com maior facilidade. A degradação do ácido ascórbico tem sido atribuída a ação de diversas enzimas: ácido ascórbico oxidase, peroxidase, citocromo oxidase e polifenol oxidase. A descompartimentação celular devido à ínjúrias, cortes ou descascamento, 
aumentam o contato entre substratos e enzimas, resultando dessa maneira em uma rápida diminuição da vitamina C (Klein, 1987).

\section{Carotenóides totais}

As abóboras cortadas em retalhos tiveram uma redução drástica nos teores de carotenóides totais do dia do processamento (dia 0) para o $3^{\circ}$ dia de armazenamento, Após esse período, os valores tenderam a ficar estáveis até o final do período de armazenamento (Figura 9). Isso pode ter ocorrido devido a maior intensidade de injúria causada pelo corte que provocou maior exposição dos tecidos à luz e ao oxigênio, que são fatores que degradam os carotenóides (Klein et al., 1985). Além disso, esse tipo de corte provocou maior extravazamento do suco celular e, provavelmente uma maior perda dos carotenóides que ficam estocados nos cromoplastos.

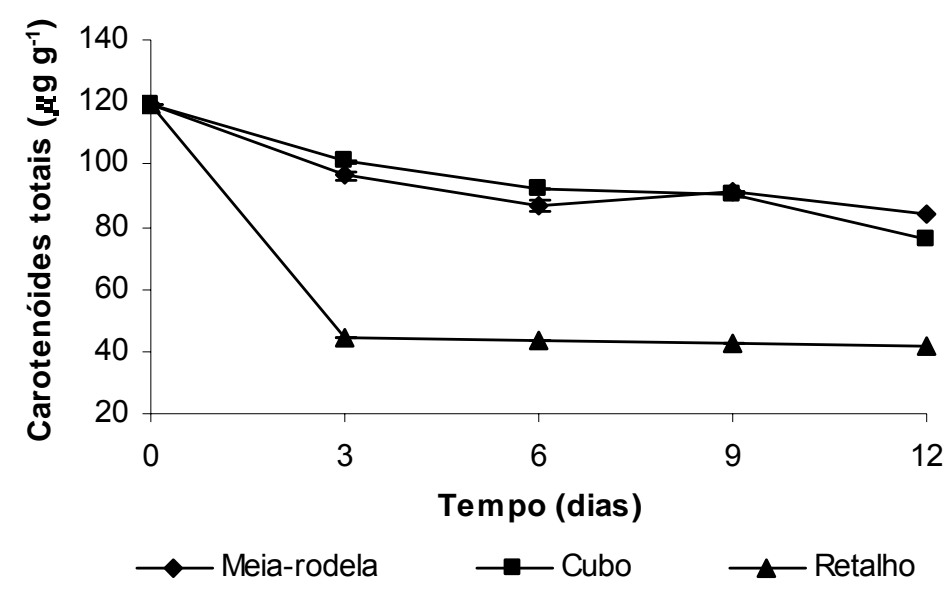

Figura 9 - Teores de carotenóides totais $\left(\mu \mathrm{g} \mathrm{g}^{-1}\right)$ de abóboras minimamente processadas submetidas a diferentes tipos de corte e armazenadas a $5^{\circ} \mathrm{C}$. Barras verticais representam erro padrão da média

Os cortes em cubos e meia-rodela não mostraram diferenças significativas entre sí nos teores de carotenóides totais, porém também houve uma redução nos teores de carotenóides totais ao longo do período de armazenamento.

A estabilidade das vitaminas nos alimentos é afetada por inúmeros fatores incluindo calor, luz oxigênio e $\mathrm{pH}$. Cada nutriente tem uma 
susceptibilidade diferente à degradação em condições adversas (Klein, 1987). Carotenóides, como precursores da vitamina $A$, são menos susceptíveis à degradação pelo calor que a vitamina $C$, mas são rapidamente oxidados quando expostos à luz e ao oxigênio (Klein et al., 1985), o que quanto se faz os cortes no processamento mínimo, expondo os tecidos internos do produto ao ambiente.

\section{Coloração}

A luminosidade $(\mathrm{L})$ das abóboras minimamente processadas com corte em meia-rodela e cubos permaneceu inalterada durante os 12 dias de armazenamento, enquanto que o corte em retalhos apresentou redução nos valores após 3 dias de armazenamento, porém, após este dia, os valores se mantiveram constantes (Figura 10).

Arruda et al. (2003) também não encontraram influência do tipo de corte nos valores de luminosidade de melões minimamente processados cortados em cubos e fatias.

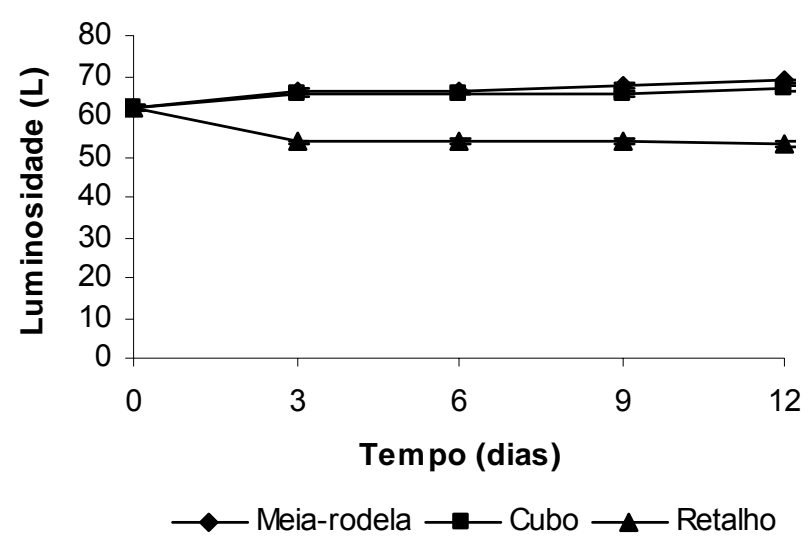

Figura 10 - Valores de luminosidade (L) de abóboras minimamente processadas submetidas a diferentes tipos de corte e armazenadas a $5^{\circ} \mathrm{C}$. Barras verticais representam erro padrão da média

No corte em cubos a intensidade de cor (cromaticidade), medida em cromaticidade $\left(C^{*}\right)$, manteve-se constante até o $9^{\circ}$ dia de armazenamento, após este dia os valores tenderam a diminuir nos três tipos de corte. Pode-se 
observar também que este tipo de corte foi o que manteve uma intensidade cor (cromaticidade) maior ao longo de todo período de armazenamento $(53,71)$, sendo seguida pelo corte em meio-rodela e por último o corte em retalhos. Os cortes em meia-rodela e retalhos apresentaram uma redução nos valores de cromaticidade do dia 0 para $03^{\circ}$ dia de armazenamento. Após este dia os valores ficaram constantes, voltando a decrescer após $09^{\circ}$ dia de armazenamento (Figura, 11).

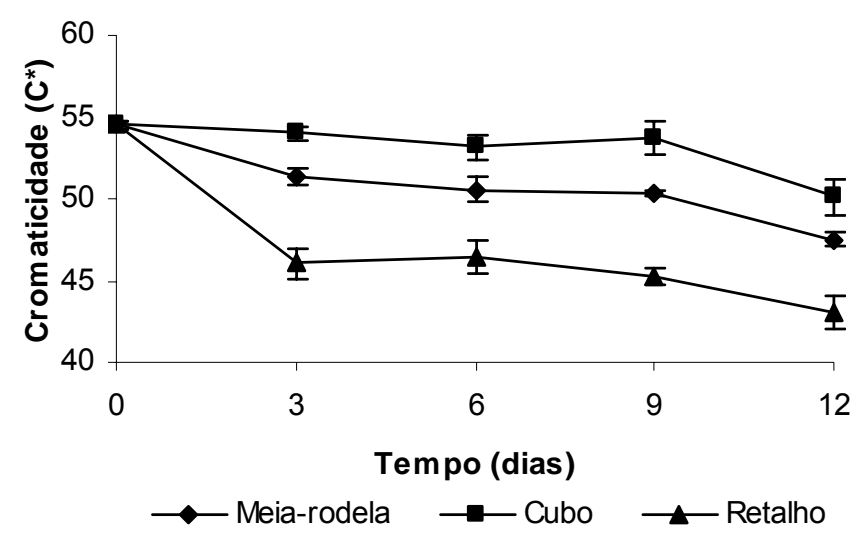

Figura 11 - Valores de cromaticidade $\left(C^{*}\right)$ de abóboras minimamente processadas submetidas a diferentes tipos de corte e armazenadas a $5^{\circ} \mathrm{C}$. Barras verticais representam o erro padrão da média

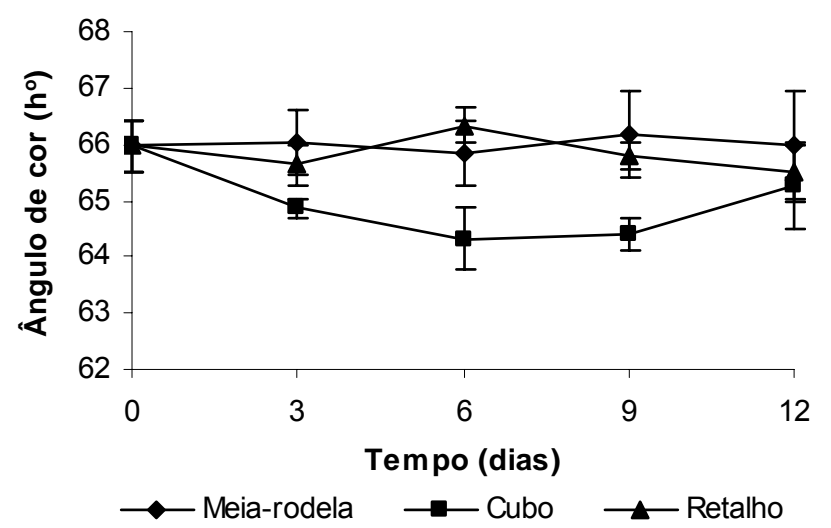

Figura 12 - Valores de angulo de cor $\left(h^{\circ}\right)$ de abóboras minimamente processadas submetidas a diferentes tipos de corte $e$ armazenadas a $5^{\circ} \mathrm{C}$. Barras verticais representam o erro padrão da média 
O corte em cubos apresentou valores de ângulo de cor $\left(\mathrm{h}^{\circ}\right)$ menores ao longo do período de armazenamento, chegando a 64,31 (Figura 12).Os corte em meia-rodela e retalhos mantiveram praticamente os valores de ângulo de cor parecidos e constantes durante o período de armazenamento (Figura 12).

Pinto (2002) também não notou mudança nos valores do ângulo de cor (hue) em melões fatiados e em cubos.

\section{Análises Microbiológicas}

Pelo fato de não existir legislações indicando limites para contagem de bactéiras pscicrotróicas, utilizou-se os parâmetros apresentados por Morton (2001), que permite a comercialização de vegetais congelados e similares com contagem total de bactérias aeróbicas mesófilas de até $10^{5}-10^{6} \mathrm{UFC} / \mathrm{g}$. Sendo estes parâmetros os mais próximos encontrados.

Até o $6^{\circ}$ dia de armazenamento os três tipos de corte apresentavam-se dentro dos limites indicados por Morton (2001). Já no último dia de análise os corte em retalhos apresentavam-se com contagem acima do permitido $\left(2,2 \times 10^{7}\right.$ UFC/g) sendo considerado impróprio para o consumo (Tabela 1).

Pôde-se verificar no $12^{\circ}$ dia armazenamento, que a contagem de bactérias foi maior no corte em retalhos, sendo seguido pelo corte em cubos e por último o corte em meia-rodela, mostrado uma relação do crescimento microbiano com o tipo de corte, sendo que o corte que provocou maior injúria nos tecidos da abóbora (retalho) foi também o que apresentou maior crescimento de bactérias pscicrotróficas (Tabela 1).

Com o processamento mínimo, o aumento em superfície pelo corte, dano e disponibilidade de nutrientes provê condições que aumentam o número e os tipos de microrganismos que aí se desenvolvem. Além, disso, o aumento da manipulação desses produtos possibilita a contaminação por patógenos (Rosa \& Carvalho, 2000). Os produtos que sofreram fracionamento serão perecíveis por várias razões, sendo elas: primeiro o tecido interno estará exposto à contaminação por qualquer agente que se encontre presente; secundariamente, 
ao ser cortado, libera-se suco celular carregado de nutrientes que fomentam o crescimento mais rápido de grandes populações microbianas e, finalmente, a manipulação extra, envolvida durante o descascamento, corte e fatiamento, provavelmente introduzirá certo número e variedades de microrganismos que geralmente não estão presentes no produto inteiro (Brackett, 1997).

Tabela 1. Contagem total de bactérias psicrotróficas em abóboras minimamente processadas em diferentes tipos de corte, armazenadas a $5^{\circ} \mathrm{C}$, utilizando-se a metodologia convencional (PCA)

Tipos de corte Dias após corte

\begin{tabular}{llll} 
& $\mathbf{0}$ & $\mathbf{6}$ & $\mathbf{1 2}$ \\
\hline Retalhos & $5,0 \times 10$ & $4,2 \times 10^{5}$ & $2,2 \times 10^{7}$ \\
Cubos & $4,0 \times 10$ & $3,4 \times 10^{5}$ & $7,5 \times 10^{6}$ \\
Meia-rodela & $2,0 \times 10$ & $2,5 \times 10^{5}$ & $5,0 \times 10^{6}$
\end{tabular}

Os resultados obtidos representam a média aritmética das UFC (unidades formadoras de colônia)/g de produto.

No presente trabalho não foram verificados as presenças coliformes totais, coliformes a $45^{\circ} \mathrm{C}$ e Salmonella, em todos os dias de análise.

Como não existe no país uma legislação específica para os vegetais minimamente processados, os resultados foram comparados com a resolução RDC n¹2 de 02 de janeiro de 2001 da Agência Nacional de Vigilância Sanitária (ANVISA) do Ministério de Saúde, que estabelece a ausência de Salmonella (em $25 \mathrm{~g}$ de produto) e permite um máximo de $10^{2} \mathrm{NMP}$ de coliformes da $45^{\circ} \mathrm{C} / \mathrm{g}$, em hortaliças in natura. Levando em consideração esses parâmetros os resultados estão dentro dos limites estabelecidos.

A ausência de coliformes a $45^{\circ} \mathrm{C} / \mathrm{g}$ e Salmonella, nas amostras analisadas, permitem afirmar que os cuidado higiênico-sanitárias tomados durante o processamento mínimo foram eficientes, enquadrando o produto nos padrões microbiológicos vigentes no país. 
No presente estudo foi verificado que o tipo de corte tem influência significativa sobre a produção de etileno, aspectos qualitativos e microbiológicos das abóboras minimamente processadas. O corte que provocou maior injúria dos tecidos (retalho) mostrou taxas de produção de etileno maiores comparado ao corte em meia-rodela, semelhantes às taxas de produção de etileno dos cortes em cubos. Além disso, este corte apresentou alterações qualitativas indesejáveis, como maior perda de massa e teores de sólidos solúveis, teores menores de ácido ascórbico e carotenóides totais. Os cortes em cubos e meia-rodela apresentaram comportamento semelhante para quase todos os parâmetros analisados.

É interessante observar que apesar das taxas de produção de etileno serem parecidas nos cortes em retalhos e cubos, o primeiro mostrou maiores perdas qualitativas e desenvolvimento microbiano mais acentuado, conseqüentemente mais rápida deterioração, em relação ao último.

\section{4 Conclusões}

- O corte em retalhos apresentou maior taxa de produção de etileno e maiores perdas qualitativas como perda de massa, sólidos solúveis, teor de ácido ascórbico e carotenóides totais. Além de proporcionar maior crescimento microbiano.

- Os cortes em cubos e meia-rodela tiveram comportamentos semelhantes para a maioria dos parâmetros analisados, exceto para o taxa de produção de etileno onde o corte em cubos apresentou pico com valores próximos ao corte em retalhos. As análises microbiológicas de ambos os tipos de corte, também, mostrou contagens de bactérias pscicrotróficas semelhantes. 


\section{QUALIDADE DE ABÓBORA MINIMAMENTE PROCESSADA ARMAZENADA EM DIFERENTES EMBALAGENS}

\section{Resumo}

O presente estudo teve como objetivo avaliar a influência de diferentes embalagens sobre qualidade e a microbiologia de abóboras minimamente processadas, armazenadas a $5^{\circ} \mathrm{C}$ e $85-90 \%$ UR, durante 12 dias. As embalagens testadas foram: filmes de cloreto de polivinila (PVC) com 12 e $17 \mu \mathrm{m}$ de espessura, filmes de polietileno de baixa densidade (PEBD) com espessuras de 48 e $102 \mu \mathrm{m}$, filme de polipropelino (PP), filme multicamada da Cryovac (BB-200) e embalagem rígida (PET), além do tratamento controle (sem modificação de atmosfera). A velocidade de modificação das concentrações gasosas no interior das embalagens foi baixa. As embalagens BB-200 e PEBD $102 \mu \mathrm{m}$ atingiram os valores recomendados no $7^{\circ}\left(7,8 \% \mathrm{CO}_{2}\right.$ e $\left.8,4 \% \mathrm{O}_{2}\right)$ e $8^{\circ}$ dias $\left(6,08 \% \mathrm{CO}_{2}\right.$ e $\left.5,94 \% \mathrm{O}_{2}\right)$ respectivamente, mas as concentrações de $\mathrm{O}_{2}$ continuaram decrescendo e as de $\mathrm{CO}_{2}$ continuaram a se elevar. As embalagens PEBD $48 \mu \mathrm{m}$ e PP atingiram os valores recomendados no final do armazenamento. As demais embalagens modificaram pouco a composição dos gases. O controle apresentou maior perda de massa em relação às embalagens testadas. Não houve influência das embalagens sobre as características qualitativas analisadas. Com relação à microbiologia, o controle, o PVC 17 $\mu \mathrm{m}$ e

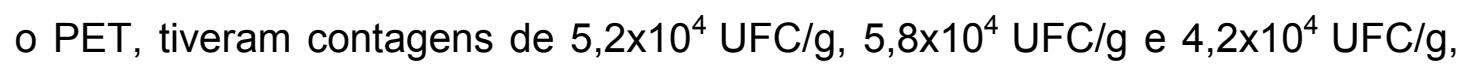
respectivamente. Não foi verificado, em nenhum dos tratamentos, crescimento de coliformes totais, coliformes a $45^{\circ} \mathrm{C}$ e Salmonella. 
Palavras-chave: Cucurbita moschata Duch., processamento mínimo, atmosfera modificada, composição gasosa, microbiologia.

\section{QUALITY OF MINIMALLY PROCESSED SQUASH STORED IN DIFFERENT PACKAGES}

\section{Summary}

The present study was carried out with the objective to verify the influence of different packages on the quality of minimally processed squashes during cold storage. The product was stored at $5^{\circ} \mathrm{C}$ and $85-90 \% \mathrm{RH}$ during 12 days. Control treatment (without atmosphere modification), rigid package (PET), film multilayer Cryovac (BB-200), polypropylene film (PP), low-density polyethylene (LDPE) film 48 and $102 \mu \mathrm{m}$ thickness, polyvinyl chloride (PVC) 12 and $17 \mu \mathrm{m}$ thickness were evaluated in this study. The velocity of modification speed of gas concentration inside the package was very low. The BB-200 e LDPE $102 \mu \mathrm{m}$ package reached the recommended values in $7^{\circ}\left(7.8 \% \mathrm{CO}_{2}\right.$ and $\left.8.4 \% \mathrm{O}_{2}\right)$ and $8^{\circ}$ day $\left(6.08 \% \mathrm{CO}_{2}\right.$ and $\left.5.94 \% \mathrm{O}_{2}\right)$ respectively. However $\mathrm{O}_{2}$ concentrations maintain decreasing and $\mathrm{CO}_{2}$ concentration staying increasing. The LDPE48 $\mu$ m e PP package reachedt the recommended values in the final of storage. The other packages showed low modification in gas composition. The control exhibits the higher weight loss if compared to the evaluated packages. There was no influence of packages on the qualitative characteristics analyzed. In respect to microbiology, the control treatment, PVC $17 \mu \mathrm{m}$ and the PET have exhibited counts of $5,2 \times 10^{4} \mathrm{UFC} / \mathrm{g}, 5,8 \times 10^{4} \mathrm{UFC} / \mathrm{g}$ and $4,2 \times 10^{4} \mathrm{UFC} / \mathrm{g}$, respectively. It was no showed total coliforms, coliforms at $45^{\circ} \mathrm{C}$ and Salmonella during cold storage.

Key-word: Cucurbita moschata Duch., modified atmosphere, gas composition, microbiology. 


\subsection{Introdução}

O consumo de produtos minimamente processados tem tido considerável aumento nos últimos anos, em função do maior interesse dos consumidores por produtos cada vez mais naturais e convenientes (Durigan \& Sargent, 1999), e também pela maior participação da mulher no mercado de trabalho, envelhecimento da população e aumento na importância das refeições coletivas (Moretti, 2001).

Segundo Vitti \& Kluge (2002a) o processamento mínimo de frutas e hortaliças se refere às operações que eliminam as partes não comestíveis, como cascas, talos e sementes, podendo seguir de corte em tamanhos menores, tornando-as prontas para o consumo imediato ou preparo sem que as hortaliças percam a condição de produto in natura. A abóbora é um bom exemplo de produto que poderia ser armazenado na forma minimamente processada, a qual, desse modo, poderia reduzir as perdas (Habibunnisa et al., 2001).

A conservação de frutas e hortaliças minimamente processadas é um processo especialmente complexo, do qual participam as células vegetais danificadas, as intactas e as mortas ou inativadas, ou seja, algumas células se encontram respirando a velocidade normal, enquanto que as danificadas respiram a velocidades maiores, em interação com outras virtualmente mortas ou inativas (Rolle \& Chism, 1987).

Depois da refrigeração, o uso de atmosfera modificada através de embalagens (MAP) tem sido o método mais eficiente para estender a vida útil de vegetais minimamente processados e vem sendo considerado como mais um passo na conservação destes produtos (Wiley, 1997).

A atmosfera modificada pode reduzir o consumo de oxigênio e a produção de $\mathrm{CO}_{2}$ (Varoquaux \& Wiley, 1997). A redução do $\mathrm{O}_{2}$ e/ou elevação do $\mathrm{CO}_{2}$ para reduzir a taxa respiratória de frutas e vegetais minimamente processados tem sido reconhecida como a principal razão dos efeitos benéficos 
da atmosfera modificada. Porém, trata-se de simplificação, já que a deterioração pós-colheita de vegetais e frutas frescas pode ser causada por muitos fatores adicionais à taxa respiratória, os quais incluem: mudanças metabólicas (mudanças bioquímicas associadas com o metabolismo respiratório, biossíntese a ação do etileno e mudanças composicionais), injúrias físicas, perda de água, desordens fisiológicas e microbiológicas (Kader, 1986).

O tipo de filme plástico utilizado na embalagem tem um papel fundamental na modificação da atmosfera, devido à sua permeabilidade e aos seus coeficientes de difusão aos gases (Wiley, 1997). Os filmes de PVC (cloreto de polivinila), PP (polipropileno) e PE (polietileno) são os mais utilizados na embalagem de produtos minimamente processados (Cantwell, 1992). O polietileno de baixa densidade (PEBD) é o filme plástico mais usado no Brasil e caracteriza-se pela boa resistência, baixo custo, disponibilidade, transparência, facilidade de termossoldagem, além de se excelente barreira ao vapor de água e não ser uma boa barreira ao oxigênio (Gava, 1984).

Por existirem poucos estudos sobre atmosfera modificada em abóboras minimamente processada, este trabalho tem como objetivo verificar o comportamento de diferentes materiais de embalagem na manutenção da qualidade da abóbora minimamente processada.

\section{2 Material e Métodos}

As abóboras maduras (Cucurbita moschata Duch.) foram colhidas na região de Tupã-SP e pré-selecionadas quanto ao tamanho, cor da casca, forma e isentas de injúrias. Os frutos foram trazidos para o Laboratório de PósColheita, do Departamento de Produção Vegetal da ESALQ/USP, onde sofreram uma lavagem inicial com detergente e água corrente, sendo seguida de uma desinfecção com solução de $200 p p m$ de cloro ativo. Após a desinfecção, as abóboras foram colocadas em câmara fria a $10 \pm 1^{\circ} \mathrm{C}$, onde permaneceram por 16 horas. 
Durante o processamento, os frutos foram cortados em rodelas de $3,0 \mathrm{~cm}$ de espessura e descascados, com auxílio de faca de aço inoxidável; as sementes foram removidas com auxílio de uma colher. As rodelas foram cortadas em cubos de $3,0 \times 3,0 \times 3,0 \mathrm{~cm}$ e imersos em água destilada para remoção do excesso de suco celular, em seguida, os cubos foram sanitizados em solução (200ppm cloro ativo) contendo Dicloro S-Triazinatriona Sódica Diidratada como princípio ativo. Após a sanitização, os pedaços sofreram enxágüe com água destilada contendo 3ppm de cloro ativo e deixados em escorredor doméstico para drenagem do excesso de água, antes de serem pesados e embalados.

\section{Tratamentos}

Os tratamentos consistiram em:

a) Controle: embalagens rígidas tipo PET com cerca de 12 furos com aproximadamente $0,8 \mathrm{~cm}$ de diâmetro para permitir a circulação de ar, com a finalidade de não provocar modificação da atmosfera no interior das embalagens;

b) Policloreto de vinila (PVC) - filmes envolvendo bandejas de poliestireno expandido, na espessura de $12 \mu \mathrm{m}$;

c) Policloreto de vinila (PVC) - filmes envolvendo bandejas de poliestireno expandido, na espessura de $17 \mu \mathrm{m}$;

d) Polietileno de baixa densidade (PEBD) - filmes na forma de saquinhos com espessura de $48 \mu \mathrm{m}$ onde foram colocadas as bandejas de poliestireno expandido contendo as abóboras;

e) Polietileno de baixa densidade (PEBD) - filmes na forma de saquinhos com espessura de $102 \mu \mathrm{m}$ onde foram colocadas as bandejas de poliestireno expandido contendo as abóboras;

f) Polipropileno (PP) - filmes na forma de saquinhos com espessura de $45 \mu \mathrm{m}$ onde dentro desta foram colocadas as bandejas de poliestireno expandido; 


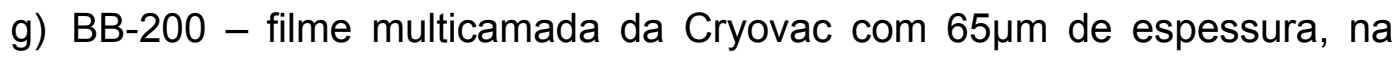
forma de saquinhos onde foram colocadas as bandejas de poliestireno expandidas com as abóboras;

h) Polietileno Tereftalato (PET) - embalagens rígidas com tampas.

Utilizou-se a colocação de bandejas de poliestireno expandido dentro das embalagens do tipo filme para melhor acondicionamento e proteção das abóboras minimamente processadas, também devido ao critério estético proporcionado às embalagens.

A caracterização das embalagens quanto a permeabilidade está descrita na Tabela 2.

Os pesos das embalagens variaram de acordo com a área de permeação das mesmas, com o objetivo de se manter a mesma relação área de permeação/massa do produto (Tabela 1).

Tabela 1. Peso das embalagens e relação área de permeação da embalagem/massa de abóbora minimamente processada

\begin{tabular}{|c|c|c|c|}
\hline Materiais de embalagem & $\begin{array}{l}\text { Área } \\
\text { permeação } \\
\left(\mathrm{cm}^{2}\right)(\mathrm{A})\end{array}$ & $\begin{array}{l}\text { de Massa } \\
\text { abóbora } \\
\text { (g) (B) }\end{array}$ & $\begin{array}{l}\text { Relação A/B } \\
\left(\mathrm{cm}^{2} / \mathrm{g}\right)\end{array}$ \\
\hline $\begin{array}{l}\text { Controle: sem modificação de } \\
\text { atomosfera }\end{array}$ & - & 270 & - \\
\hline $\begin{array}{l}\text { PEBD } 48 \mu \mathrm{m} \text { : filme de } \\
\text { polietileno de baixa densidade }\end{array}$ & 940 & 370 & 2,54 \\
\hline 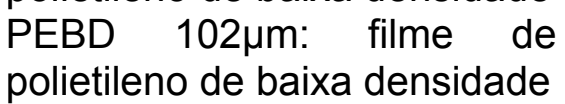 & 940 & 370 & 2,54 \\
\hline $\begin{array}{l}\text { PVC } 12 \mu \mathrm{m}: \text { filme de } \\
\text { policloreto de vinila }\end{array}$ & 682 & 270 & 2,52 \\
\hline $\begin{array}{l}\text { PVC } 17 \mu \mathrm{m}: \text { filme de } \\
\text { policloreto de vinila }\end{array}$ & 682 & 270 & 2,52 \\
\hline PP: filme de polipropileno & 940 & 370 & 2,54 \\
\hline $\begin{array}{l}\text { BB-200: filme multicamadas } \\
\text { da Cryovac }\end{array}$ & 940,5 & 370 & 2,54 \\
\hline $\begin{array}{l}\text { PET: embalagem de } \\
\text { polietileno tereftalato rígida }\end{array}$ & 1016 & 400 & 2,54 \\
\hline
\end{tabular}


Tabela 2. Caracterização dos materiais de embalagem

\begin{tabular}{|c|c|c|}
\hline Materiais de embalagem & $\begin{array}{l}\text { Espessura } \\
(\mu \mathrm{m})\end{array}$ & $\begin{array}{l}\mathrm{TPO}_{2}{ }^{*} \\
\left(\mathrm{~mL} \mathrm{~m}{ }^{-2} \mathrm{dia}^{-1}\right)\end{array}$ \\
\hline $\begin{array}{l}\text { PEBD } 48 \mu \mathrm{m} \text { : filme de polietileno de baixa } \\
\text { densidade }\end{array}$ & 48 & 4013 \\
\hline $\begin{array}{l}\text { PEBD } 102 \mu \mathrm{m} \text { : filme de polietileno de baixa } \\
\text { densidade }\end{array}$ & 102 & 1920 \\
\hline PVC $12 \mu \mathrm{m}$ : filme de policloreto de vinila & 12 & 11165 \\
\hline PVC $17 \mu \mathrm{m}$ : filme de policloreto de vinila & 17 & 9038 \\
\hline PP: filme de polipropileno & 45 & 1880 \\
\hline BB-200: filme multicamadas da Cryovac & 65 & 9 \\
\hline PET: embalagem de polietileno tereftalato rígida & - & 12081 \\
\hline
\end{tabular}

* Taxa de permeabilidade ao oxigênio $\left(\mathrm{TPO}^{2}\right)$ a $23^{\circ} \mathrm{C}$, a seco a $1 \mathrm{~atm}$ de gradiente de pressão parcial de gás permanente.

O produto embalado foi armazenado durante 12 dias a $5 \pm 1^{\circ} \mathrm{C}$ e $80-85 \%$ UR. As análises físicas, químicas e físico-químicas foram realizadas no $0,3^{\circ}$, $6^{\circ}, 9^{\circ}$ e $12^{\circ}$ dias de armazenamento e as análises microbiológicas foram realizadas nos dias 0,6 e 12 .

\section{Análises físicas, químicas e físico-químicas}

As determinações realizadas foram: a) Concentração de $\mathrm{O}_{2}$ e $\mathrm{CO}_{2}$ no interior das embalagens: determinada com auxílio de um analisador de gases PBI Dansensor 9900, modelo Check Mate. Cada embalagem continha um septo de silicone por onde eram feitas as leituras, os resultado foram expresso em \% do gás; b) Perda de massa (\%), através da diferença entre a massa inicial e final da repetição; c) Firmeza (Newtons), com auxílio de penetrômetro manual; d) Coloração interna ( $L, C^{*} e h^{\circ}$ ), com auxílio de colorímetro Minolta; e) Teor de sólido solúveis ('Brix), utilizando um refratômetro (Atago); f) Acidez titulável (\%), através de titulação com $\mathrm{NaOH} 0,1 \mathrm{~N} ; \mathrm{g}$ ) Teor de ácido ascórbico, obtida através de titulação com DCFI, com resultados expresso em mg $100 \mathrm{~g}^{-1}$; h) Teor de 
carotenóides totais $\left(\mu \mathrm{g} \mathrm{g}{ }^{-1}\right.$ ), com auxílio de espectrofotômetro (FEMTO-700 Plus).

Maiores detalhes sobre as análises podem ser encontradas no capítulo 3 , nas páginas 22 a 25 .

\section{Análises microbiológicas}

As análises microbiológicas realizadas foram: contagem de bactérias psicrotróficas (UFC/g), pelo método do plaqueamento em profundidade com diluições de $10^{-1}$ a $10^{-3}$; contagem de coliformes fecais (NMP), pela técnica de Tubos Múltiplos, utilizando as diluições de $10^{-1}$ a $10^{-3}$; e detecção de Salmonella (ausência ou presença), com auxílio de kits ('1-2 Test' - Biocontrol/USA).

Maiores detalhes sobre as análises microbiológicas podem ser encontradas no capítulo 3, nas páginas 15 a 28 .

\section{Delineamento experimental}

O delineamento experimental utilizado foi inteiramente casualizado no esquema fatorial $8 \times 5$. Os fatores estudados foram tipos de embalagem, em oito níveis, e tempo de armazenamento, em cinco níveis (0, 3, 6, 9 e 12 dias). Foram utilizadas quatro repetições, sendo cada uma composta com embalagem de abóbora minimamente processada, com peso variando entre 270 a $400 \mathrm{~m}$, de acordo com o tipo de embalagem, com o objetivo de manter uma relação de área de permeação/massa de produto constante. Para a caracterização do lote experimental (tempo zero), quatro amostras foram analisadas logo após o processamento mínimo do produto.

Os resultados obtidos das análises físicas químicas e físico-químicas foram submetidos à análise do erro padrão. As diferenças entre dois tratamentos maior que a soma dos erros padrões foram consideradas significativas $(P<0,05)$ (Moretti et al., 2002). 
Para avaliação dos aspectos microbiológicos os resultados foram expressos em UFC/g de produto para bactérias psicrotróficas, NMP/g para coliformes totais e presença ou ausência de Salmonella em $25 \mathrm{~g}$ de produto.

\section{3 Resultados e Discussão}

\section{Composição gasosa das embalagens}

Segundo Schlimme \& Rooney (1997) a utilização de polímeros como materiais para embalagem para criar uma atmosfera modificada ao redor dos produtos minimamente processados pode ser considerado um fator de conservação do produto. Cantwell (1992) recomenda as concentrações de 2 a $8 \%$ para $\mathrm{O}_{2}$ e de 5 a $15 \%$ para $\mathrm{CO}_{2}$, para preservação de frutas e hortaliças minimamente processadas. No presente experimento verificou-se, que a velocidade de modificação das concentrações gasosas no interior das embalagens foi muito baixa (Figura 1). As embalagens BB-200 e PEBD 102 $\mu \mathrm{m}$ atingiram os valores recomendados no $6^{\circ}$ e $8^{\circ}$ dias, respectivamente, mas ao invés de se estabilizarem as concentrações de $\mathrm{O}_{2}$ continuaram decrescendo e as concentrações de $\mathrm{CO}_{2}$ continuaram a se elevar. Já as embalagens PEBD $48 \mu \mathrm{m}$ e PP atingiram os valores recomendados somente $12^{\circ}$ dias de armazenamento, ou seja, no final do período de armazenamento, não permitindo verificar se estas concentrações se estabilizariam após este dia.

O filme BB-200, por ser considerado material de alta barreira (Tabela 2), alcançou as concentrações recomendadas no $6^{\circ}$ dia de armazenamento, porém, após este período, os teores de $\mathrm{O}_{2}$ continuaram decrescendo, chegando a valores de $0,04 \%$ ( $\left.12^{\circ} \mathrm{dia}\right)$, enquanto que os valores de $\mathrm{CO}_{2}$ continuaram a aumentar, atingindo $16,37 \%$ no $12^{\circ}$ dia de armazenamento (Figura 1). Nestas concentrações gasosas as abóboras podem estar em condições de respiração anaeróbica. Segundo Kader (1986), a diminuição do teor de $\mathrm{O}_{2}$ disponível para frutas e vegetais reduz a taxa respiratória (produção de $\mathrm{CO}_{2} /$ consumo de $\mathrm{O}_{2}$ ), 
que geralmente requer no mínimo de 1 a $3 \%$ de oxigênio, dependendo do produto, para evitar a mudança de respiração aeróbica para anaeróbica.

Arruda et al. (2003b) estudando atmosfera modificada passiva em melões minimamente processados, obtiveram resultados diferentes. Os autores verificaram que os melões embalados com filme BB-200 tiveram a composição gasosa estabilizada em torno de $18,58 \%$ de $\mathrm{O}_{2}$ e $3,74 \%$ de $\mathrm{CO}_{2}$.

As embalagens PET, PVC $12 \mu \mathrm{m}$ e PVC $17 \mu \mathrm{m}$ sofreram uma modificação da composição dos gases muito pequena, ficando aquém daquela recomendada por Cantwell (1992). A embalagem PET, devido a sua deficiência na vedação, manteve as concentrações de $\mathrm{O}_{2}$ semelhantes às do controle (sem modificação da atmosfera) e as concentrações de $\mathrm{CO}_{2}$ variando de 0,83 a $1,57 \%$ (Figura 1).

Como as taxas de permeabilidade ao $\mathrm{O}_{2}$ dos filmes de PVC $12 \mu \mathrm{m}$ e PVC $17 \mu \mathrm{m}$ foram as mais altas dentre os filmes analisados $\left(11165 \mathrm{~mL} \mathrm{~m}^{-2} \mathrm{dia}^{-1} \mathrm{e}\right.$ $9038 \mathrm{~mL} \mathrm{~m} \mathrm{~m}^{-2} \mathrm{dia}^{-1}$, respectivamente) (Tabela 2), as concentrações de $\mathrm{O}_{2}$ no interior das embalagens ficaram em torno de $17,61 \%$ para o PVC $12 \mu \mathrm{m}$ e $17,87 \%$ para PVC $17 \mu \mathrm{m}$. 

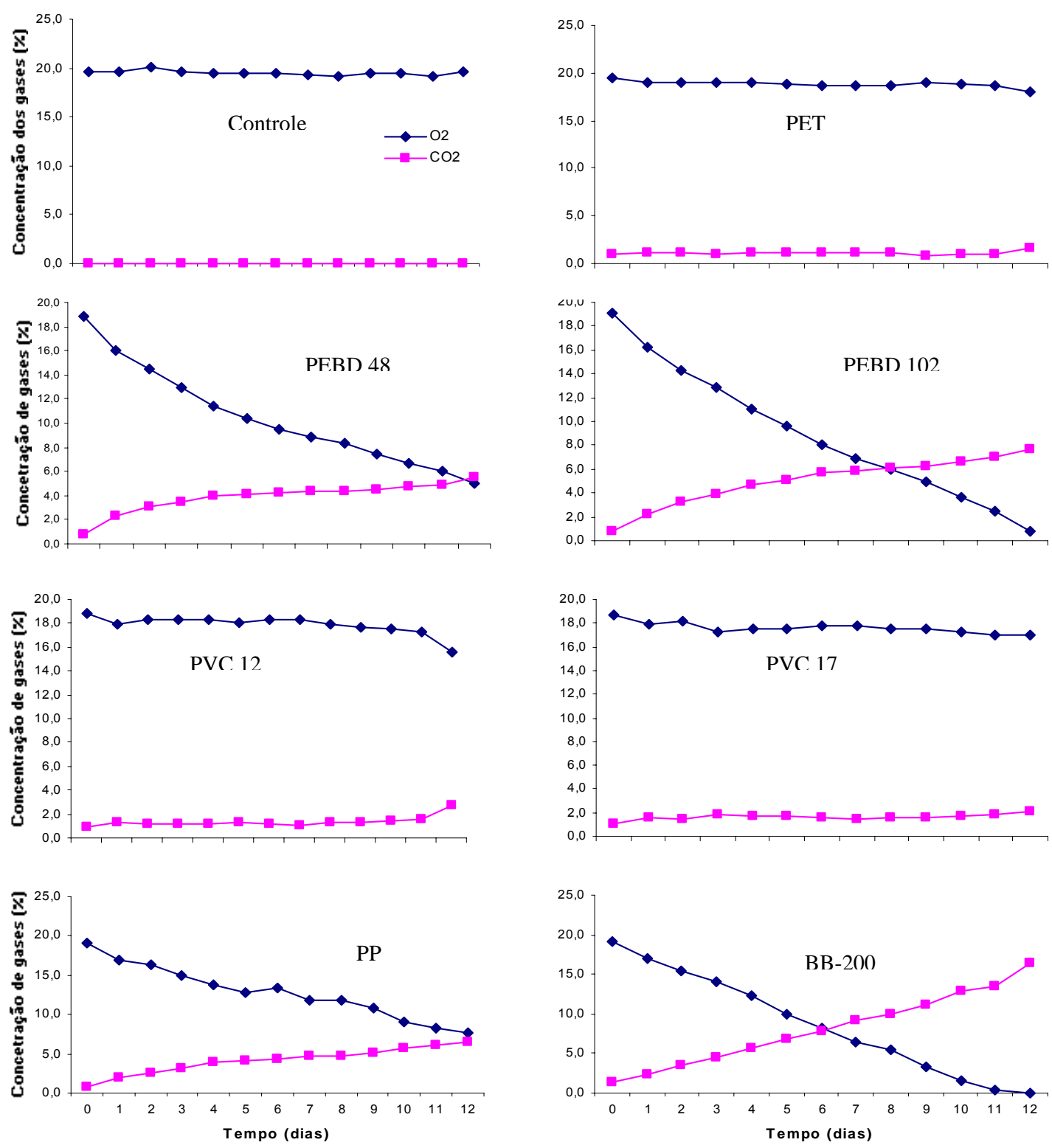

Figura 1 - Composição gasosa dos espaços livres das embalagens com abóboras minimamente processadas, armazenadas a $5^{\circ} \mathrm{C}$, sendo: Controle: sem modificação de atmosfera; PET: embalagem de polietileno tereftalato rígida; PEBD 48 $\mu \mathrm{m}$ : polietileno de baixa densidade com $48 \mu \mathrm{m}$ de espessura; PEBD $102 \mu \mathrm{m}$ : polietileno de baixa densidade com 102 $\mu \mathrm{m}$ de espessura; PVC $12 \mu \mathrm{m}$ : policloreto de vinila com $12 \mu \mathrm{m}$ de espessura; PVC $17 \mu \mathrm{m}$ : policloreto de vinila com $17 \mu \mathrm{m}$ de espessura; PP: polipropileno com $45 \mu \mathrm{m}$ de espessura; e BB200 filme multicamadas da Cryovac com $65 \mu \mathrm{m}$ de espessura 


\section{Perda de massa}

O tratamento controle (sem modificação de atmosfera) teve uma perda de massa muito acentuada em relação aos outros tratamentos, chegando a perdas de até 12,05\% (Figura 2). Este valor está acima dos valores críticos de perdas de massa indicados por Finger \& Vieira (1997), que são de 5 a 10\%.
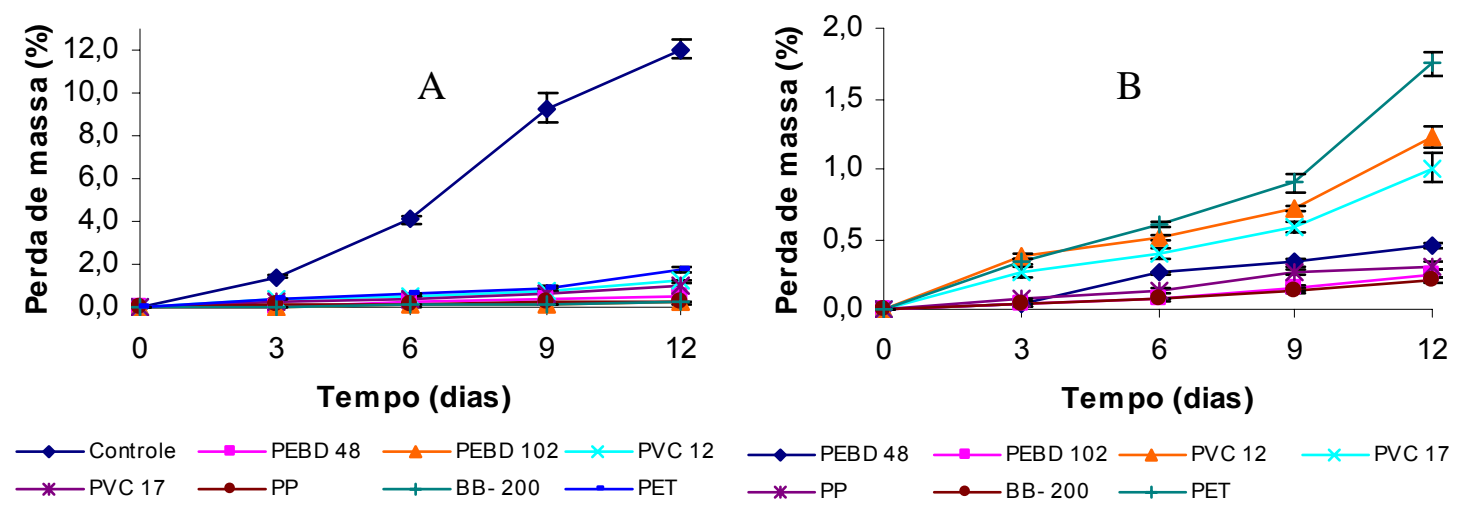

Figura 2 - Perda de massa (\%) de abóboras minimamente processadas acondicionadas em diferentes tipos de embalagens $e$ armazenadas a $5^{\circ} \mathrm{C} . A=$ perda de massa das embalagens em comparação ao controle; $\mathrm{B}=$ perda de massa em comparação entre as embalagens. Barras verticais representam o erro padrão da média

Entre as embalagens a que demonstrou maior perda de massa foi a PET $(1,74 \%)$, seguida da PVC $12(1,22 \%)$ e $17 \mu \mathrm{m}(1,0 \%)$. As embalagens com os filmes BB-200 e PEBD $102 \mu \mathrm{m}$ foram as que apresentaram menores perdas de massa. Estes valores ficam bem abaixo dos valores indicado como críticos por Finger \& Vieira (1997).

A embalagem funciona como a membrana que foi retirada com 0 processamento, reduzindo a perda de água, o ataque de microrganismos e outras reações (Durigan \& Cassaro, 2000).

A perda de água pode ser uma das principais causas de deterioração dos vegetais minimamente processados, já que resulta em perdas quantitativas, perdas na aparência (murchamento), na textura (amolecimento) e na qualidade nutricional (Porte \& Maia, 2001). A perda de água pelos vegetais minimamente 
processada pode ser minimizada pela atmosfera modificada ou controlada, devido à elevada umidade relativa propiciada (Kader, 1986).

\section{Firmeza}

As abóboras embaladas com PET, PVC $12 \mu \mathrm{m}$ e controle apresentaram uma leve tendência de aumento nos valores de firmeza, atingindo valores de $103,57 \mathrm{~N} ; 102,12 \mathrm{~N}$ e $100,35 \mathrm{~N}$ (Figura 3). Isto pode ter ocorrido devido às diferenças nas perdas de água propiciados pelas embalagens. Esta perda de água pode ter ocasionado murchamento dos pedaços dificultando a penetração do penetrômetro. Este fato pode ser observado quando se comparam as curvas de perda de massa da embalagens PET, PVC 12 $\mu \mathrm{m}$ e controle (Figura 2A) com as curvas de firmeza das mesmas na Figura 3. As três embalagens que apresentaram maiores perdas de massa, tiveram também aumento da firmeza ao longo período de armazenamento.

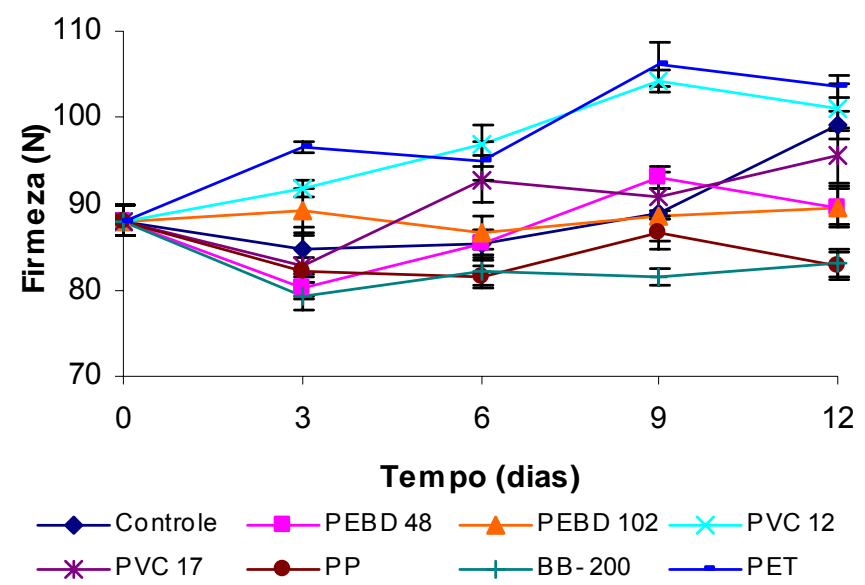

Figura 3 - Valores de firmeza $(N)$ de abóboras minimamente processadas acondicionadas em diferentes tipos de embalagens e armazenadas a $5^{\circ} \mathrm{C}$. Barras verticais representam o erro padrão da média

\section{Sólidos solúveis}

Com exceção do tratamento controle e PET, as embalagens mantiveram os teores de sólidos solúveis constantes ao longo do período de armazenamento, não mostrando diferenças entre os tratamentos (Figura 4). As abóboras embaladas em PET e o controle tiveram uma redução no $3^{\circ}$ dia de 
armazenamento atingindo valores de $5,45^{\circ} \mathrm{Brix}$ e $5,15^{\circ} \mathrm{Brix}$, respectivamente. Após este dia os valores tenderam a se manter constantes até $012^{\circ}$ dia de armazenamento.

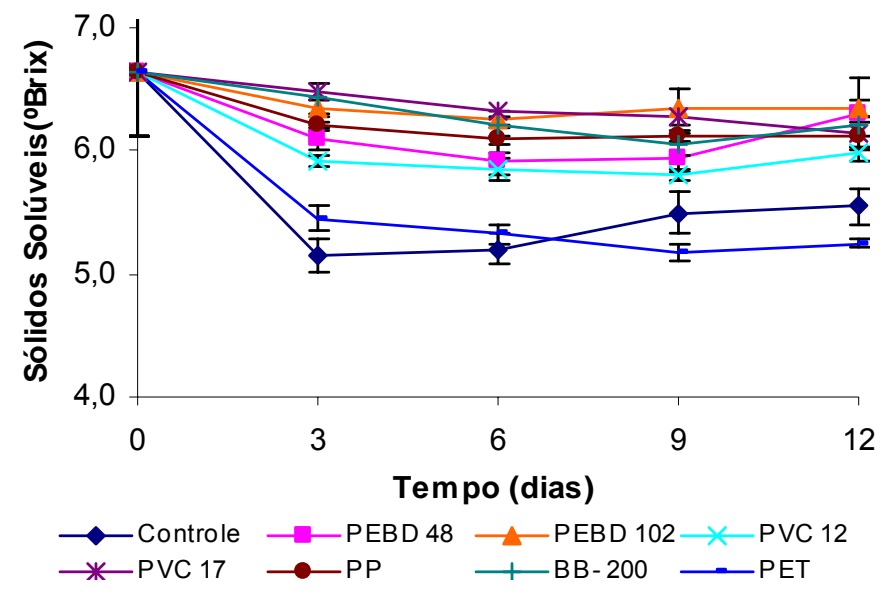

Figura 4 - Teores de sólidos solúveis ( ${ }^{\circ}$ Brix) de abóboras minimamente processadas acondicionadas em diferentes tipos de embalagens e armazenadas a $5^{\circ} \mathrm{C}$. Barras verticais representam o erro padrão da média

A redução dos teores de sólidos solúveis do controle pode ter sido pelo consumo de açúcares pela respiração do produto, considerando que sem a modificação de atmosfera não houve alteração na sua taxa respiratória em relação às abóboras minimamente processadas armazenadas dentro de embalagens. As abóboras acondicionadas em embalagem PET mostram o mesmo comportamento, pois a vedação deste tipo de embalagens não foi muito eficiente e com isso as concentrações gasosas no interior das embalagens ficaram próximas à concentração do ar atmosférico.

Habibunnisa et al. (2001) observaram reduções nos teores sólidos solúveis de morangas minimamente processadas embaladas em filmes de PEBD. Os autores verificaram reduções de $0,27^{\circ}$ Brix para o controle no $8^{\circ}$ dia de armazenamento e $0,05^{\circ}$ Brix para o no $25^{\circ}$ dia de armazenamento.

Gil et al. (2002) relataram que o teor de sólidos solúveis de tomates minimamente processadas variou de $4,7^{\circ}$ Brix a $5,4^{\circ}$ Brix, mas não sofreu efeito 
significativo em cinco diferentes embalagens testadas durante 10 dias armazenamento.

\section{Acidez titulável}

Houve um pequeno de aumento nos valores de acidez titulável para as

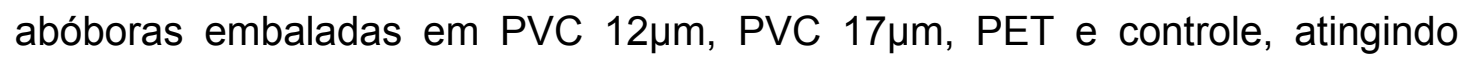
valores de 0,$108 ; 0,114 ; 0,102$ e $0,980 \%$ ( $12^{\circ}$ dia), respectivamente. As demais embalagens não modificaram os valores de acidez titulável das abóboras minimamente processadas (Figura 5).

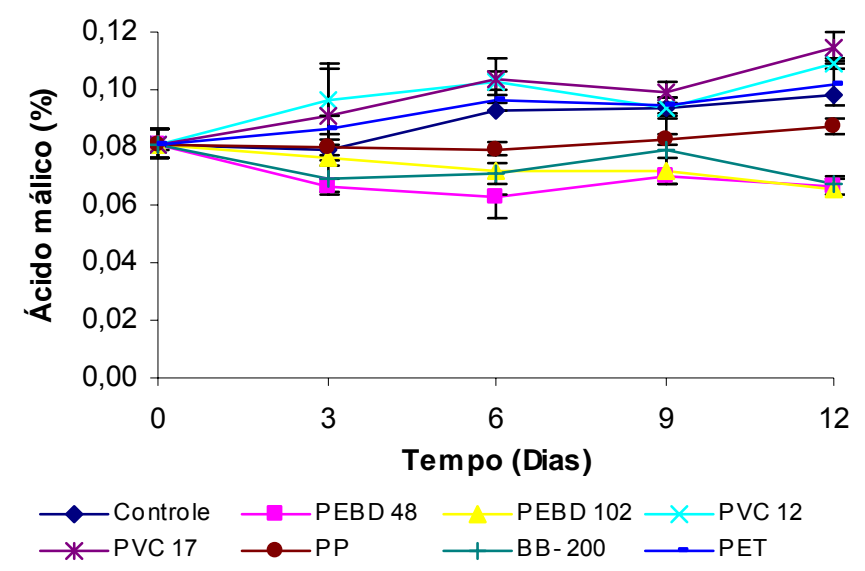

Figura 5 - Valores de acidez titulável (\% ácido málico) de abóboras minimamente processadas acondicionadas em diferentes tipos de embalagens e armazenadas a $5^{\circ} \mathrm{C}$. Barras verticais representam o erro padrão da média

Habibunnisa et al. (2001) verificaram aumento dos teores de acidez titulável em morangas minimamente processadas, de $0,38 \%$ para $0,39 \%$ e $0,42 \%$ nos tratamentos controle e embalados em PEDB, respectivamente.

Artés \& Martinez (1999) observaram pequena ou nenhuma mudança nos valores de acidez titulável para couves-flores mantidas a $1,5^{\circ} \mathrm{C}$, com exceção para as embaladas em PEBD $20 \mu \mathrm{m}$ que tiveram sua acidez aumentada de 0,10 para $0,16 \mathrm{~g}$ ácido málico/ $100 \mathrm{~g}$.

Como as abóboras apresentam valores baixos de acidez titulável, as diferenças ocorridas são pouco perceptíveis. 


\section{Ácido ascórbico}

O armazenamento de alimentos sem uma proteção externa (embalagem) conduz à oxidação e à destruição de muitos nutrientes, inclusive das vitaminas (Gava, 1984).

As curvas dos teores de ácido ascórbico, medidas em $\mathrm{mg}$ ácido ascórbico $100 \mathrm{~g}^{-1}$, mostram um comportamento semelhante entre todas as embalagens. A embalagem BB-200 apresentou valores mais elevados nos teores de vitamina $C$, enquanto que o controle foi o que teve maiores reduções nos teores de ácido ascórbico (Figura 6). Isto ocorre porque em atmosfera de armazenamento com baixos teores de oxigênio, a quebra de ácido ascórbico é inibida. A oxidação de vitamina $\mathrm{C}$ é regulada, primeiramente, pelo ácido ascórbico oxidase e outras enzimas que apresentam baixa afinidade com o oxigênio. Por isso, em baixos teores deste gás ocorre retardamento na mudança de ácido ascórbico para ácido desidroascórbico (Weichmann, 1987).

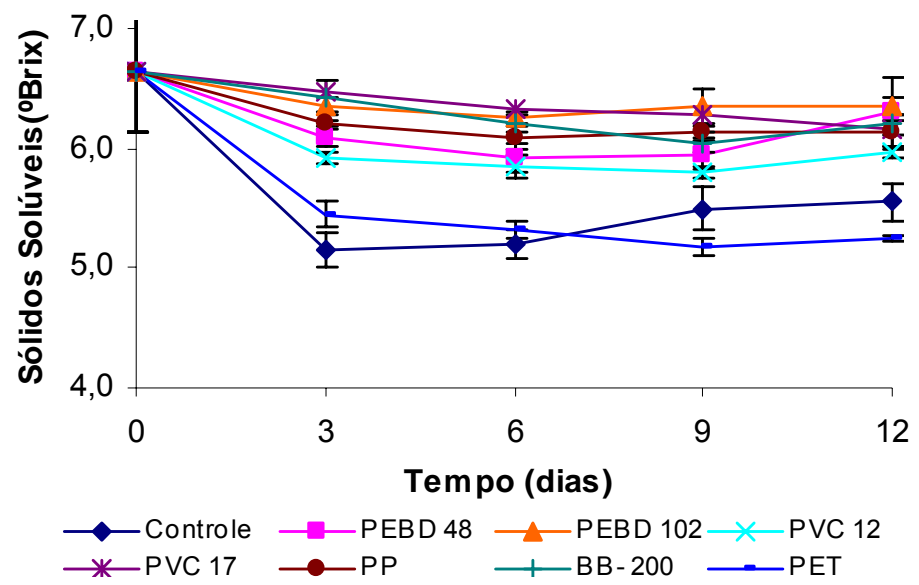

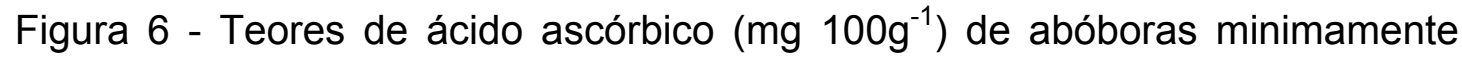
processadas acondicionadas em diferentes tipos de embalagens e armazenadas a $5^{\circ} \mathrm{C}$. Barras verticais representam o erro padrão da média

Teores de ácido ascórbico e clorofilas foram mantidas constantes quando brócolis minimamente processadas foram mantidas em atmosferas com aproximadamente $9 \%$ de $\mathrm{CO}_{2}$ e $3 \%$ de $\mathrm{O}_{2}$ (Barth et al., 1993). Habibunnisa et al. (2001) observaram reduções nos teores de vitamina C de 2,08 mg ácido 
ascórbico/100g no controle e 1,48 mg ácido ascórbico/100g em morangas minimamente processadas embaladas com filme de PEBD.

\section{Carotenóides totais}

Os carotenóides são muito susceptíveis á isomerização e oxidação durante o processamento e armazenamento. Isso tem como conseqüências práticas à perda da coloração e da atividade biológica, e a formação de compostos voláteis que fazem parte da composição agradável ou desagradável do flavor nos alimentos (Rodriguez-Amaya, 2001). A estabilidade dos carotenóides é afetada por inúmeros fatores, tais como: calor, luz oxigênio, $\mathrm{pH}$, presença de metais, enzimas, e materiais de embalagem (Klein, 1987; Rodriguez-Amaya, 2001).

Considerando-se que as embalagens de BB-200 proporcionaram maiores reduções nas concentrações de $\mathrm{O}_{2}$ e $\mathrm{CO}_{2}$ (Figura 1), verificou-se que estas embalagens provocaram menores perdas nos teores de carotenóides totais (Figura 7). Neste tratamento, o produto apresentou teores mais elevados em relação aos outros tratamentos no $6^{\circ}$ dia $\left(95,27 \mu \mathrm{g} \mathrm{g}^{-1}\right)$ e no $9^{\circ}$ dia $(91,06 \mu \mathrm{g}$ $\mathrm{g}^{-1}$ ) de armazenamento. Além disso, houve um acréscimo nos teores de carotenóides totais do $3^{\circ}$ dia $\left(85,14 \mu \mathrm{g} \mathrm{g}^{-1}\right)$ para o $6^{\circ}\left(95,27 \mu \mathrm{g} \mathrm{g}^{-1}\right)$. Do $9^{\circ}$ para o $12^{\circ}$ dia de armazenamento houve uma queda drástica nos valores de carotenóides totais, podendo isto estar relacionado com a concentração de $\mathrm{O}_{2}$ muito baixa e a concentração de $\mathrm{CO}_{2}$ muito alta. Assim, neste período, as abóboras poderiam estar em anaerobiose, provocando maiores degradações.

De acordo com Weichmamm (1986), citado por Klein (1987), as retenções de carotenóides foram melhorers quanto menores os níveis de $\mathrm{O}_{2} \mathrm{e}$ em concentrações de $\mathrm{CO}_{2}$ entre $7,5 \%$ e $10 \%$ o conteúdo de carotenóides pareceu melhorar nas frutas e hortaliças.

Para as demais embalagens houve um comportamento semelhante para os teores de carotenóides. 


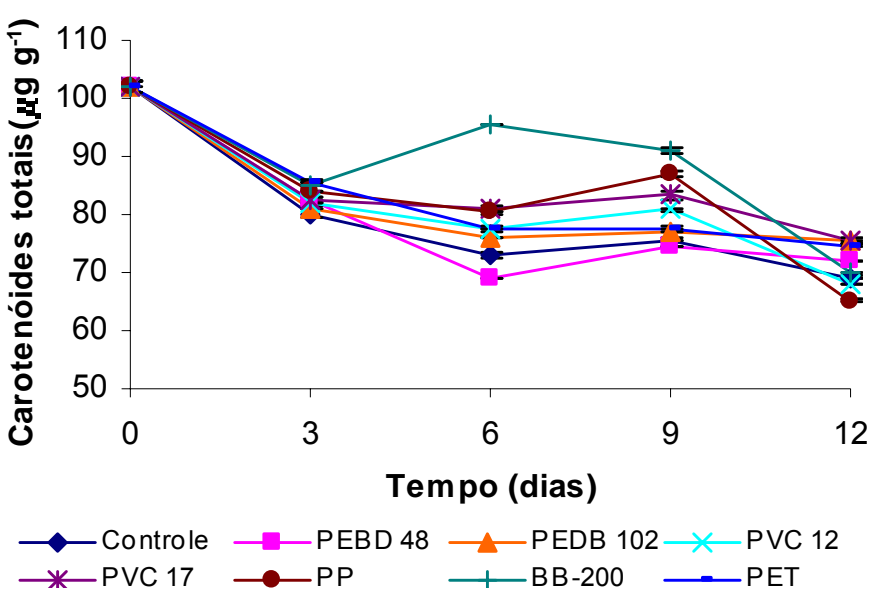

Figura 7 - Teores de carotenóides totais $\left(\mu \mathrm{g} \mathrm{g}^{-1}\right)$ de abóboras minimamente processadas acondicionadas em diferentes tipos de embalagens e armazenadas a $5^{\circ} \mathrm{C}$. Barras verticais representam o erro padrão da média

Habibunnisa et al. (2001) estudando abóboras do tipo moranga, verificaram que o produto embalado em filme PEBD manteve o teor de carotenóides totais constante durante 25 dias, enquanto que as abóboras do controle (sem modificação de atmosfera) tiveram reduções de aproximadamente $16 \mu \mathrm{g} 100 \mathrm{~g}^{-1}$, aos oito dias de armazenamento. De igual forma, Barth \& Zhuang, (1996) observaram que o armazenamento de brócolis em condições de atmosfera modificada retardou a degradação de carotenóides a temperatura de $5^{\circ} \mathrm{C}$. Em pêras, o conteúdo de carotenóides foi preservado com poucas mudanças em armazenamento durante 8 dias a $5^{\circ} \mathrm{C}$ e $2 \mathrm{kPa} \mathrm{O}_{2}+$ $12 \mathrm{kPa} \mathrm{CO} 2$ (Palmer-Writh \& Kader, 1997).

\section{Coloração}

Houve uma tendência de aumento na luminosidade (L), independentemente do tipo de embalagem (Figura 8). Isso poder ter ocorrido devido à desidratação na superfície dos pedaços de abóboras minimamente processadas, a qual causou um esbranquiçamento dos tecidos da parte externa dos pedaços das abóboras, semelhante ao "White blush" que ocorre em cenouras. 
O controle e a embalagem PET foram os tratamentos que tiveram maior aumento da luminosidade e também os que tiveram maiores perdas de massa (Figura 2). Isto pode dar um indício de que o esbranquiçamento seja causado, principalmente, pela desidratação dos tecidos do produto.

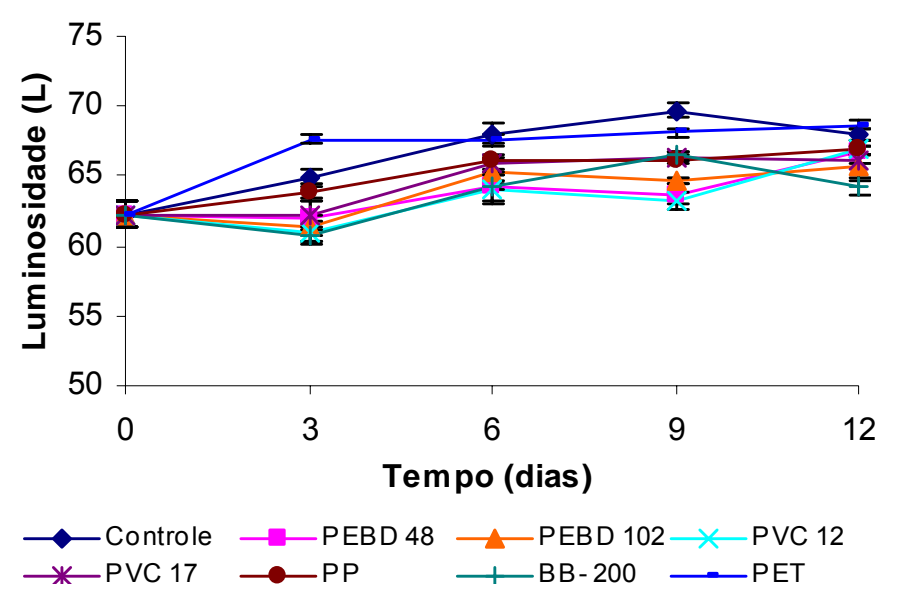

Figura 8 - Valores de luminosidade $(L)$ de abóboras minimamente processadas acondicionadas em diferentes tipos de embalagens e armazenadas a $5^{\circ} \mathrm{C}$. Barras verticais representam o erro padrão da média

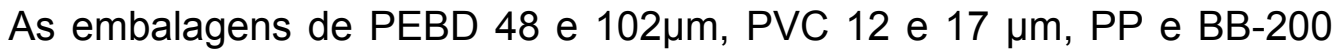
não tiveram influência significativa sobre os valores de $L$ das abóboras minimamente processadas.

As abóboras embaladas em filme PVC $12 \mu \mathrm{m}$ apresentaram maiores valores de cromaticidade, os quais permaneceram constantes ao longo do período de armazenamento (Figura 9). Já as embalagens com BB-200 foram as que mostraram menores valores de cromaticidade $(46,64)$, porém constantes. 


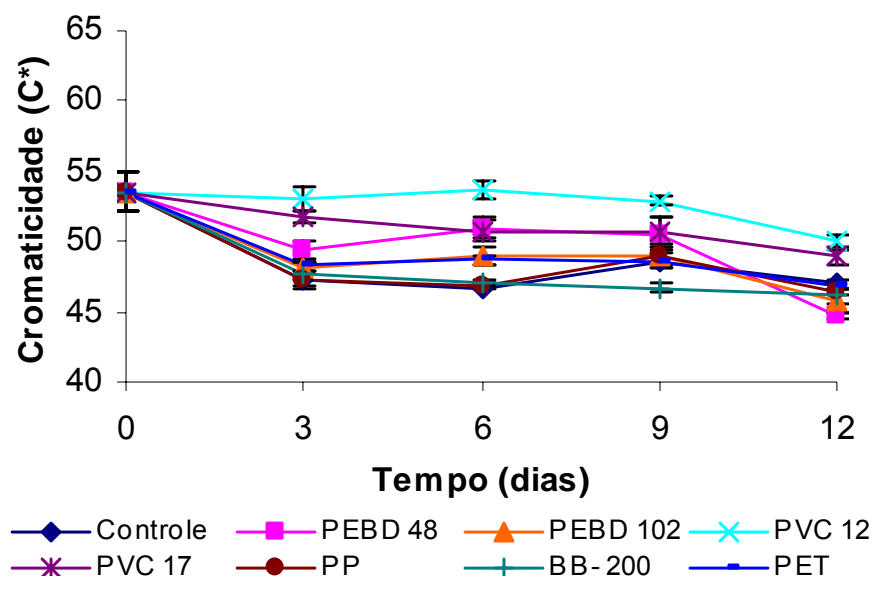

Figura 9 - Valores de cromaticidade $\left(C^{*}\right)$ de abóboras minimamente processadas acondicionadas em diferentes tipos de embalagens e armazenadas a $5^{\circ} \mathrm{C}$. Barras verticais representam o erro padrão da média

As curvas dos valores de ângulo de cor $\left(h^{\circ}\right)$, mostraram um comportamento semelhante para a maioria das embalagens. $O$ controle foi 0 tratamento que apresentou os maiores valores, enquanto que na embalagem de PVC $12 \mu \mathrm{m}$ foram verificados os menores valores de $h^{\circ}$ (Figura 10).

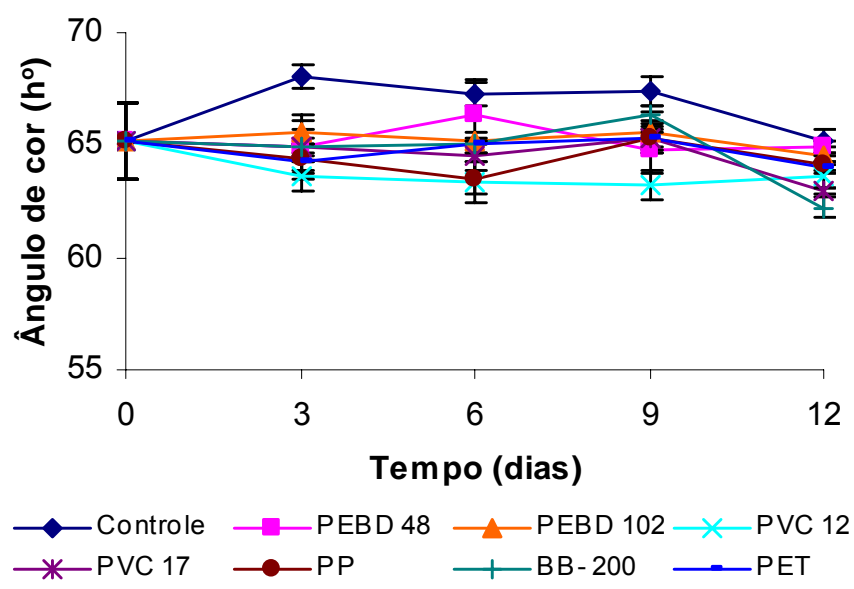

Figura 10 - Valores de ângulo de cor $\left(h^{\circ}\right)$ de abóboras minimamente processadas acondicionadas em diferentes tipos de embalagens e armazenadas a $5^{\circ} \mathrm{C}$. Barras verticais representam o erro padrão da média 


\section{Análises microbiológicas}

A atmosfera no interior da embalagem afeta não apenas o metabolismo dos alimentos, mas é fundamental na seleção da microflora presente (Porte \& Maia, 2001). O impacto sobre os microrganismos depende do organismo em si, da concentração dos gases, da temperatura e da tolerância fisiológica do alimento (Brackett, 1997).

$\mathrm{O} \mathrm{CO}_{2}$ interfere no metabolismo celular dos microrganismos mais sensíveis, como os gram-negativos, aeróbios e bactérias psicrotróficas e bolores (Daniels et al., 1985; Hintlian \& Hotchkiss, 1986). Entretanto, altas concentrações podem selecionar anaeróbios facultativos ou obrigatórios, como as bactérias lácticas e bactérias acéticas, e eucariotas unicelulares (Porte \& Maia, 2001).

Até $\circ 6^{\circ}$ dia de armazenamento (Tabela 3 ) todos os tratamentos apresentaram contagem de bactérias psicrotróficas abaixo dos limites recomendados por Morton (2001), de $10^{5}-10^{6} \mathrm{UFC} / \mathrm{g}$ de bactérias aeróbias mesófilas para vegetais congelados e similares. Seguiu-se essa recomendação devido à inexistência de limites tolerados para bactérias psicrotróficas em produtos minimamente processados e essas indicações foram mais próximas encontradas na literatura.

No $12^{\circ}$ dia de armazenamento as abóboras embaladas com filmes PVC $12 \mu \mathrm{m}, \mathrm{PEBD} 102 \mu \mathrm{m}$ e PP apresentaram contagens de $1,6 \times 10^{6} \mathrm{UFC} / \mathrm{g}, 1,0 \times 10^{6}$ UFC/g, $1,3 \times 10^{6} \mathrm{UFC} / \mathrm{g}$, respectivamente. Estes valores estão nos limites máximos recomendados por Morton (2001). Já as abóboras embaladas nos filmes PVC 17 e BB-200, PET e o tratamento controle apresentaram contagens de $3,8 \times 10^{4} \mathrm{UFC} / \mathrm{g}, 3,8 \times 10^{4} \mathrm{UFC} / \mathrm{g}, 3,8 \times 10^{4} \mathrm{UFC} / \mathrm{g}$ e $3,8 \times 10^{4} \mathrm{UFC} / \mathrm{g}$, contagens consideradas dentro dos limites aceitáveis (Tabela 3 ).

O tratamento controle, onde se esperava uma contagem elevada de bactérias psicrotróficas, pelo fato dos pedaços de abóboras ficarem expostos ao ambiente (sem proteção), apresentou contagem menor que algumas 
embalagens. Isto pode ter ocorrido devido à maior desidratação ocorrida neste tratamento, o que diminui a atividade de água $\left(\mathrm{a}_{\mathrm{w}}\right)$ na superfície dos pedaços de abóbora e dificultou o crescimento microbiano.

Todas as amostras analisadas da embalagem BB-200 apresentaram crescimento de um fungo deteriorante nas análises a partir do $6^{\circ}$ dia de armazenamento.

Tabela 3. Contagem total de bactérias psicrotróficas, em abóboras minimamente processadas armazenadas em diferentes tipos de embalagens, a $5^{\circ} \mathrm{C}$, utilizando-se a metodologia convencional (PCA)

Tipos de embalagens

\section{Dias após corte}

$0 \quad 6$

Controle

$2,0 \times 10$

6

12

PVC $12 \mu \mathrm{m}$

$2,0 \times 10$

$2,0 \times 10$

$2,0 \times 10$

$2,0 \times 10$

$2,0 \times 10$

$2,0 \times 10$

$2,0 \times 10$

$3,5 \times 10^{2}$

$2,5 \times 10^{2}$

$2,5 \times 10^{2}$

$7,9 \times 10^{4}$

$5,5 \times 10^{2}$

$4,7 \times 10^{4}$

$3,0 \times 10^{2}$

$2,3 \times 10^{3}$
$5,2 \times 10^{4}$

$1,6 \times 10^{6}$

$3,6 \times 10^{4}$

$1,4 \times 10^{5}$

$1,0 \times 10^{6}$

$1,3 \times 10^{6}$

$5,8 \times 10^{4}$

$4,2 \times 10^{4}$

Os resultados obtidos representam a média aritmética das UFC (unidades formadoras de colônia)/g de produto.

Não foi verificado, em nenhum dos tratamentos, crescimento de coliformes totais, coliformes a $45^{\circ} \mathrm{C}$ e Salmonella, ficando dentro dos limites estabelecidos pela resolução RDC n¹2 de 02 de janeiro de 2001 da Agência Nacional de Vigilância Sanitária (ANVISA) do Ministério de Saúde, que estabelece a ausência de Salmonella (em $25 \mathrm{~g}$ de produto) e permite um máximo de $10^{2} \mathrm{NMP}$ de coliformes da $45^{\circ} \mathrm{C} / \mathrm{g}$ em hortaliças in natura. Decidiu-se seguir esta legislação, considerando-se que não existe uma legislação específica para produtos minimamente processados e esta resolução é a mais próxima que se pode seguir. 
Estes resultados mostram a eficiência dos cuidados higiênico-sanitários tomados durante as etapas do processamento.

Como a taxa respiratória das abóboras minimamente processadas é baixa, a modificação da atmosfera dentro das embalagens foi muito lenta. Com isso, nenhuma das embalagens apresentou vantagem significativa para manutenção da qualidade das abóboras minimamente processadas. Porém, ficou claro a necessidade da utilização de embalagens para este produto, desde que possuam um sistema de selamento eficiente para evitar, principalmente, as perdas de massa e sólidos solúveis. Talvez a utilização de atmosfera modificada ativa seja mais eficiente que a atmosfera modificada passiva, o que é objetivo de futuros estudos.

\section{4 Conclusões}

- O uso de atmosfera modificada passiva não foi eficiente para a manutenção da qualidade de abóboras minimamente processadas.

- Observou-se a necessidade de embalagem para este produto, desde que bem vedada, para evitar perdas qualidade das abóboras minimamente processadas, principalmente com relação à perda de massa e sólidos solúveis. 


\section{AÇÃO DE DIFERENTES SANITIZANTES SOBRE A FLORA MICROBIANA DE ABÓBORA MINIMANETE PROCESSADA.}

\section{Resumo}

As abóboras minimamente processadas foram submetidas a sanitização com diferentes sanitizantes com o objetivo de verificar a eficiência destes sobre a flora microbiana do produto. Os sanitizantes utilizados foram: Dicloro STriazinatriona Sódica Diidratada (SUMAVEG ${ }^{\circledR}$ ), Dióxido de Cloro (TECSA$\mathrm{CLOR}^{\circledR}$ ), Dicloro Isocianurato de Sódio Diidratada (CLOR-IN 1), Ácido Peracético (TSUNAMI 100) e Ácido Acético. Todos os sanitizantes foram eficientes na redução da contagem de bactérias psicrotróficas e na eliminação de coliformes totais e coliformes a $45^{\circ} \mathrm{C}$. O Dicloro Isocianurato de Sódio apresentou melhores resultados no controle do crescimento de bactérias psicrotróficas, com contagens < 10 UFC/g. Embora o Ácido Acético tenha sido eficiente na redução da contagem de bactérias psicrotróficas, este sanitizante provocou amolecimento das abóboras, além das maiores perdas nos teores de ácido ascórbico e carotenóides totais, o que provocou perda da coloração. Os sanitizantes Dicloro S-Triazinationa Sódica Diidratada, Dicloro Isocianurato de Sódio e Dióxido de Cloro não interferiram nas características qualitativas e nutricionais das abóboras minimamente processadas. Não foi detectada presença de Salmonella durante o período de armazenamento.

Palavras-chave: Cucurbita moschata Duch., cloro ativo, sanificação, microbiologia,. 


\section{ACTION OF DIFFERENT SANITIZERS IN MICROBIOLOGICAL FLORAOF MINIMALLY PROCESSED SQUASH}

\section{Summary}

With the objective to verify the efficiency in the microorganism control the minimally processed squashes were submitted to sanitization with different sanitizers. The utilized sanitizers were: Sodium Diclorine S-Triazinatrione $\left(\right.$ SUMAVEG $\left.{ }^{\circledR}\right)$, Chlorine Dioxide $\left(\right.$ TECSA-CLOR $\left.^{\circledR}\right)$, Sodium Diclorine Isocianurate (CLOR-IN 1), Peracetic acid (TSUNAMI 100) and Acetic acid. All sanitizers showed efficience in respect to the decrease in the $t$ psychrotrophic bacteria counts, and in the growth of total coliforms and coliform at $45^{\circ} \mathrm{C}$. The Sodium Diclorine Isocianurate showed the best results in relation to the control of psychrotrophic bacteria with count $<10 \mathrm{UFC} / \mathrm{g}$. Peracetic acid, although has been efficient to reduce psychrotrophic bacteria, caused softening of the product, besides higher loss of ascorbic acid and carotenoids and lack of color. Sodium Dichloride S-Triazinatrione, Sodium Diclorine Isocianurate and Dióxid of Clor did not influence the qualitative and nutritional characteristics of minimally processed squash. It was no showed Salmonella during cold storage.

Key-words: Cucurbita moschata Duch., active chlorine, sanitation, microbiology. .

\subsection{Introdução}

A crescente participação da mulher no mercado de trabalho, o aumento no número de restaurantes que oferecem refeições a quilo e fast foods, a redução no tamanho dos núcleos familiares, o menor tempo para o preparo das refeições e a preocupação com alimentos mais saudáveis, fazem com que os consumidores brasileiros demandem cada vez mais produtos que ofereçam praticidade e segurança (Frutifatos, 1999). Como possuem características de 
frutas e hortaliças in natura e por serem de rápido preparo ou consumo, os vegetais minimamente processados tem conquistado a preferência do consumidor (Oliveira \& Valle, 2000).

Por outro lado, os alimentos processados minimamente constituem ótimos meios de crescimento para os microrganismos, devido à presença de tecidos lesados a do alto teor de umidade dentro das embalagens, o que aumenta o seu potencial de deterioração. Por serem muito manipulados, esses produtos podem ter sua microbiota aumentada e alterada e, eventualmente, veicularem microrganismos patogênicos.

Com o objetivo de diminuir a contaminação e garantir a segurança microbiológica dos produtos, os vegetais minimamente processados normalmente são submetidos à sanitização (Oliveira \& Valle, 2000). Na literatura encontramos comumente a indicação do uso de 50 a 200ppm de cloro livre para sanitização de frutas antes e após o corte (Bett et al, 2001; Dong et al, 2000; Gorny et al, 2000). Porém, quando utiliza-se o cloro necessita-se subseqüentemente o enxagüe do produto para eliminação do cloro residual para manutenção das mesmas propriedades sensoriais de um produto sem sanitização (Ahvenainen, 1996). A segurança do uso de sanitizantes a base de hipoclorito está em questionamento e conseqüentemente alternativas de sanitizantes para os produtos minimamente processados são necessários (Hurst, 1995).

Alguns autores têm sugerido o uso de ácidos orgânicos como o peracético ou octanóico para a sanitização dos produtos minimamente processados, sendo estes poderosos agentes oxidantes (Hilgren \& Salverda, 2000). No mesmo grupo de ácidos orgânicos, autores com Fantuzzi (1999) que utilizam o ácido acético como santizante. A atividade antimicrobiana dos ácidos orgânicos depende de dois fatores: o baixo $\mathrm{pH}$ e a estrutura do ácido (Cherry, 1999). Segundo Hurst (1995) outro produto que está sendo muito estudado em processamento mínimo é o dióxido de cloro, o qual também tem ação antimicrobiana, devido a sua ação oxidante. 
Visando um melhor aproveitamento, a agregação de valor o aumento na conveniência e a segurança para o consumo, o presente trabalho teve como objetivo avaliar a eficiência de diferentes sanitizantes sobre a flora microbiana das abóboras minimamente processadas.

\subsection{Material e Métodos}

Abóboras maduras (Cucurbita moschata Duch.) colhidas na região de Tupã-SP foram pré-selecionadas quanto ao tamanho, cor da casca e forma. Foram escolhidas ainda abóboras isentas de injúrias. Os frutos foram trazidos para o Laboratório de Pós-Colheita, do Departamento de Produção Vegetal da ESALQ/USP, em Piracicaba-SP. Primeiramente as abóboras sofreram uma lavagem inicial com detergente e água corrente, sendo em seguida feita uma desinfecção com solução com os diferentes sanitizantes descritos posteriormente. Após a desinfecção, as abóboras foram colocadas em câmara fria a $10 \pm 1^{\circ} \mathrm{C}$, onde permaneceram por 16 horas constituindo em um período de descanso para reduzir seu metabolismo.

Durante o processamento, os frutos foram cortados em rodelas $(3,0 \mathrm{~cm}$ de espessura) e descascados, com auxílio de faca de aço inoxidável. As sementes foram removidas com uma colher. As rodelas foram cortadas em cubos de 3,0 x 3,0 x 3,0cm e imersos em água destilada, para remoção do excesso de suco celular. Em seguida, os cubos passaram por uma sanitização. Após a sanitização, os pedaços foram enxaguados, quando a especificação da sanitizante utilizado indicava este procedimento. Em seguida os pedaços de abóbora foram deixados em escorredor doméstico para drenagem do excesso de água, antes de serem pesados e embalados. Foram confeccionadas embalagens de $300 \mathrm{~g}$ de abóbora minimamente processada. Os pedaços foram colocados em bandejas de poliestireno expandido, cobertos com filme de PVC com $12 \mu \mathrm{m}$ de espessura

Todo o processamento foi realizado dentro de uma câmara fria asséptica, à temperatura de $10 \pm 1^{\circ} \mathrm{C}$. Os operadores utilizaram roupas protetoras 
adequadas e toda água utilizada para a lavagem, sanitização e enxágüe foi destilada e previamente resfriada a $5^{\circ} \mathrm{C}$.

\section{Tratamentos}

Os santizantes foram utilizados conforme nas concentrações indicadas pelos fabricantes e seguindo as especificações dos mesmos, sendo eles:

a) Dicloro S-Triazinatriona Sódica Diidratada (pó) - nome comercial SUMAVEG ${ }^{\circledR}$, produzido pela Diversey Lever - Indústria Gessy Lever Ltda. Foi utilizada solução com concentração de $0,66 \%$ do produto (200ppm de cloro ativo), que contém 3\% de cloro ativo. As abóboras foram imersas durante 3 minutos e depois enxaguadas (2 min.) em uma solução contendo 3ppm de cloro ativo, para retirada do excesso de cloro.

b) Dióxido de Cloro (líquido) - nome comercial TECSA-CLOR ${ }^{\circledR}$, produzido pela Serquímico Ltda. Foi utilizada uma solução contendo 50ppm do produto onde, as abóboras permaneceram imersas por 3 minutos. 0 fabricante garantiu a ausência da necessidade de enxágüe. Este produto é um produto aceito pelo IBD (Instituto de Biodinâmica) para utilização em produtos orgânicos.

c) Dicloro Isocianurato de Sódio Diidratada (pastilha) - nome comercial CLOR-IN 1, produzido pela Acuapura Ltda. Foi utilizada uma solução com 10ppm de cloro ativo, onde as abóboras permaneceram imersas durante 3 minutos, o enxágüe não foi recomendado pela fabricante. Este produto também é um produto aceito pelo IBD.

d) Ácido Peracético (líquido) - nome comercial TSUNAMI 100, produzido pela Ecolab Química Ltda. Foi utilizada uma solução com concentração de 533ppm do produto, o que equivale a 80ppm de ácido peracético. As abóboras ficaram imersas nessa solução por 3 minutos. $O$ fabricante não indica a necessidade de enxágüe. Este produto também é um produto aceito pelo IBD. 
e) Ácido Acético (líquido p. a.) - produzido pela Merk. A concentração utilizada foi de $1 \%$ sendo a concentração utilizada por Fantuzzi (1999) para sanitização de repolho minimamente processado. As abóboras ficaram imersas durante 3 minutos nesta solução. Não se realizou enxágüe.

As abóboras minimamente processadas foram armazenado durante 12 dias a $5 \pm 1^{\circ} \mathrm{C}$ e $80-85 \%$ UR. As análises físicas, químicas e físico-químicas foram realizadas no $0,3^{\circ}, 6^{\circ}, 9^{\circ}$ e $12^{\circ}$ dia de armazenamento e as análises microbiológicas foram realizadas no $0,6^{\circ}$ e $12^{\circ}$ dias.

\section{Análises físicas, químicas e físico-químicas}

As determinações realizadas foram: a) Perda de massa (\%), através da diferença entre a massa inicial e final da repetição; b) Firmeza (Newtons), com auxílio de penetrômetro manual; c) Coloração $\left(L, C^{*}\right.$ e $\left.h^{0}\right)$, com auxílio de colorímetro (Minolta); d) Teor de sólido solúveis ( ${ }^{\circ} \mathrm{Brix}$ ), utilizando um refratômetro (Atago); e) Acidez titulável (\%), através de titulação com $\mathrm{NaOH}$ $0,1 \mathrm{~N}$; f) Teor de ácido ascórbico ( $\left.\mathrm{mg} 100 \mathrm{~g}^{-1}\right)$, obtida através de titulação com DCFl; g) Teor de carotenóides totais $\left(\mu \mathrm{g} \mathrm{g}{ }^{-1}\right)$, com auxílio de espectrofotômetro (FEMTO-700 Plus). Realizou-se também a medição do pH das soluções dos santizantes.

Maiores detalhes das análises podem ser encontradas no capítulo 3, nas páginas 22 a 25 .

\section{Análises microbiológicas}

As análises microbiológicas realizadas foram: contagem de bactérias psicrotróficas (UFC/g), pelo método do plaqueamento em profundidade com diluições de $10^{-1}$ a $10^{-3}$; contagem de coliformes fecais (NMP), pela técnica de Tubos Múltiplos, utilizando as diluições de $10^{-1}$ a $10^{-3}$; e detecção de Salmonella (ausência ou presença), com auxílio de kits ('1-2 Test' - Biocontrol/USA). 
As análises microbiológicas realizadas estão descritas de forma mais detalhada no capítulo 3, nas páginas 25 a 28 .

\section{Delineamento experimental}

O delineamento experimental foi inteiramente casualizado em esquema fatorial $5 \times 5$. Os fatores estudados foram sanitizantes, em cinco níveis, e tempo de armazenamento, em cinco níveis (0, 3, 6, 9 e 12 dias). Foram utilizadas quatro repetições por tratamento, sendo cada uma composta de $300 \mathrm{~g}$ de abóbora minimamente processada. Para a caracterização do lote experimental (tempo zero), quatro amostras foram analisadas logo após o processamento do produto.

Os resultados obtidos das análises físicas químicas e físico-químicas foram submetidos à análise do erro padrão. As diferenças entre dois tratamentos maior que a soma dos erros padrões foram consideradas significativas $(P<0,05)$ (Moretti et al., 2002).

Para avaliação dos aspectos microbiológicos os resultados foram expressos em UFC/g de produto para bactérias psicrotróficas, NMP/g para coliformes totais e presença ou ausência de Salmonella em $25 \mathrm{~g}$ de produto.

\subsection{Resultados e Discussão}

\section{Análises microbiológicas}

Todos os sanitizantes utilizados foram eficientes na redução da contagem de bactérias psicrotróficas. Na matéria-prima a contagem inicial de $3,2 \times 10^{3} \mathrm{UFC} / \mathrm{g}$ foi reduzida para menos que $10 \mathrm{UFC} / \mathrm{g}$, quando as abóboras foram sanitizadas com Dicloro Isocianurato de Sódio ou com Ácido Acético (Tabela 1). Os tratamentos com Dicloro S-Triazinationa Sódica Diidratada, Dióxido de cloro e Ácido Peracético reduziram a contagem para 1,0×10 UFC/g; 1,5x10 UFC/g; 2,5x10 UFC/g, respectivamente. 
Fantuzzi (1999) não encontrou diferença significativa na redução da contagem de bactéria aeróbias mesófilas entre as amostras de repolho tratadas com solução de $200 \mathrm{mg} \mathrm{L}^{-1}$ de hipoclorito de sódio, $0,66 \%$ de Dicloro STriazinationa Sódica Diidratada (SUMAVEG ${ }^{\circledR}$ ) ou $1 \%$ de ácido acético, chegando a redução de 1,8 ciclos logarítmicos.

Zhang \& Farber (1996) verificaram redução de 1,1 ciclos logarítmicos na contagem de Listeria monocytogenes em alfaces minimamente processadas sanitizadas com dióxido de cloro (5ppm/10min).

Como ainda não existe uma legislação para bactéria psicrotróficas em vegetais minimamente processados utilizou-se como base a recomendação de Morton (2001), para contagem de bactéria aeróbias mesófilas em vegetais congelados e similares, que permite o máximo de contagem de $10^{5}-10^{6} \mathrm{UFC} / \mathrm{g}$.

No $12^{\circ}$ dia de armazenamento todas as amostras ainda estavam dentro do recomendado por Morton (2001), sendo o tratamento com Dicloro STriazinationa Sódica Diidratada o santizante o qual apresentou contagem mais elevada $\left(2,8 \times 10^{4} \mathrm{UFC} / \mathrm{g}\right)$ e o tratamento com Dicloro Isocianurato de Sódio o qual apresentou contagem mais reduzida (<10 UFC/g). Piagentini et al. (1997) notaram, também, um aumento na população de bactérias psicrotróficas em repolhos minimamente processados, que passou de $10^{2}$ para $10^{5} \mathrm{UFC} / \mathrm{g}$ nas amostras mantidas a $4^{\circ} \mathrm{C}$, após o quarto dia de armazenamento.

Segundo Caruso \& Camargo (1984) quantidades elevadas de

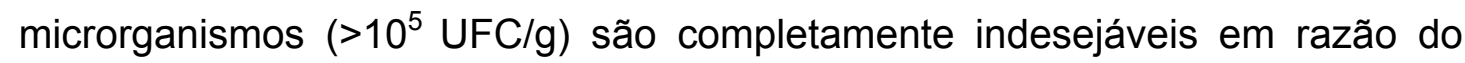
risco do alimento estar deteriorado, com perda real ou potencial das qualidades organolépticas, comprometimento da aparência do alimento e presença de microrganismos patogênicos.

O tratamento com o sanitizante Dicloro Isocianurato de Sódio foi o que manteve a contagem de bactéria psicrotróficas mais baixa ao longo de todo a período de armazenamento (Tabela 1). 
Tabela 1. Contagem total de bactérias psicrotróficas, em abóbora minimamente processada, tratada com diferentes sanitizantes, armazenadas, utilizando-se a metodologia convencional

Sanitizantes

Dias após corte*

0

12

Dicloro S-Triazinationa

Sódica Diidratada

$1,0 \times 10$

$8,5 \times 10^{2}$

$2,8 \times 10^{4}$

Dicloro Isocianurato de

Sódio

$<10 \quad<10 \quad<10$

Dióxido de Cloro

$1,5 \times 10 \quad 2,0 \times 10 \quad 4,3 \times 10^{2}$

Ácido Peracético

$2,5 \times 10 \quad 1,4 \times 10^{2} \quad 1,0 \times 10^{2}$

Ácido Acético

$<10 \quad 4,5 \times 10 \quad 3,0 \times 10$

*Os resultados obtidos representam a média aritmética das UFC (unidades formadoras de colônia)/g de produto.

${ }^{*}$ Contagem inicial (matéria-prima) $=3,2 \times 10^{3} \mathrm{UFC} / \mathrm{g}$.

Considerando que no país ainda não existe uma legislação específica para os vegetais minimamente processados, os resultados foram comparados com a resolução RDC $n^{0} 12$ de 02 de janeiro de 2001 da Agência Nacional de Vigilância Sanitária (ANVISA) do Ministério de Saúde, que estabelece a ausência de Salmonella (em $25 \mathrm{~g}$ de produto) e permite um máximo de $10^{2} \mathrm{NMP}$ de coliformes da $45^{\circ} \mathrm{C} / \mathrm{g}$, em hortaliças in natura. Assim, os resultados obtidos no presente trabalho estão dentro dos limites estabelecidos.

Todos os santizantes foram eficazes na eliminação de coliformes fecais e coliformes a $45^{\circ} \mathrm{C}$. A matéria-prima apresentava contagens no limite máximo permitido pela legislação, sendo elas de 9,2x $0^{2} \mathrm{NMP}$ de coliformes totais/g e $2,2 \times 10^{2}$ NMP de coliformes a $45^{\circ} \mathrm{C} / \mathrm{g}$, respectivamente, porém todos os sanitizantes conseguiram eliminar completamente todos os coliformes (Tabelas 2 e 3), tornando as abóboras seguras para o consumo humano. 
Não houve presença de Salmonella em nenhuma das amostras, inclusive na matéria-prima (Tabela 4).

Assim, pode-se afirmar que os cuidados higiênico-sanitários tomados durante o processamento mínimo foram eficientes, enquadrando o produto nos padrões microbiológicos vigentes no país.

Tabela 2. NMP de coliformes totais, em abóboras minimamente processadas tratadas com diferentes sanitizantes, armazenadas a $5 \pm 1^{\circ} \mathrm{C}$ e $85 \pm 5 \%$ UR, utilizando-se a metodologia de tubos múltiplos

Sanitizantes

Dias após corte*

0

12

Dicloro S-Triazinationa

Sódica Diidratada

Ausência

Ausência

Ausência

Dicloro Isocianurato de

Sódio

Ausência Ausência Ausência

Dióxido de Cloro

Ausência Ausência Ausência

Ácido Peracético

Ausência Ausência Ausência

Ácido Acético

Ausência Ausência Ausência

*Os resultados obtidos representam o NMP de coliformes totais/g de produto.

${ }^{* *}$ Contagem inicial (matéria-prima) $=9,2 \times 10^{2} \mathrm{NMP}$ coliformes totais $/ \mathrm{g}$ 
Tabela 3. NMP de coliformes a $45^{\circ} \mathrm{C}$, em abóboras minimamente processadas tratadas com diferentes sanitizantes, armazenadas a $5 \pm 1^{\circ} \mathrm{C}$ e $85 \pm 5 \%$ UR, utilizando-se a metodologia de tubos múltiplos

Sanitizantes Dias após corte*

$\begin{array}{lll}0 & 6 & 12\end{array}$

Dicloro S-Triazinationa

Sódica Diidratada

Ausência Ausência Ausência

Dicloro Isocianurato de

Sódio

Ausência Ausência Ausência

Dióxido de Cloro

Ausência

Ausência

Ausência

Ácido Peracético

Ausência

Ausência

Ausência

Ácido Acético

Ausência

Ausência

Ausência

${ }^{*}$ Os resultados obtidos representam o NMP de coliformes a $45^{\circ} \mathrm{C} / \mathrm{g}$ de produto. ${ }^{* *}$ Contagem inicial (matéria-prima) $=2,2 \times 10^{2} \mathrm{NMP}$ coliformes a $45^{\circ} \mathrm{C} / \mathrm{g}$.

Tabela 4. Detecção de Salmonella em $25 \mathrm{~g}$ de abóbora minimamente processadas Tratadas com difentes sanitizantes, armazenadas a $5 \pm 1^{\circ} \mathrm{C}$ e $85+5 \%$ UR, utilizando-se o kit ' $1-2$ test' da BioControl/USA

Sanitizantes Dias após corte

$\begin{array}{lll}0 & 6 & 12\end{array}$

Dicloro S-Triazinationa

Sódica Diidratada

Ausência Ausência Ausência

Dicloro Isocianurato de

Sódio

Ausência Ausência Ausência

Dióxido de Cloro

Ausência

Ausência

Ausência

Ácido Peracético

Ausência

Ausência

Ausência

Ácido Acético

Ausência

Ausência

Ausência

*Detecção inicial (matéria-prima) = ausência em 25g. 


\section{Perda de massa}

Houve um aumento da perda de massa durante o período de armazenamento, independentemente do tipo de sanitizante utilizado. Segundo Durigan (2004), o processamento mínimo leva a um aumento na relação superfície/volume, facilitando a perda de massa, principalmente água.

Os tratamentos de Ácido Peracético e Ácido Acético foram os que sofreram maiores perdas de massa em relação aos outros sanitizantes utilizados, chegando a $1,61 \%$ de perda de massa no caso do Ácido Peracético, mas essas perdas são bem inferiores aos limites recomendados por Finger \& Vieira (1997) 5 a $10 \%$ de perda de massa para hortaliças. Os demais sanitizantes tiveram perdas de massa semelhantes.

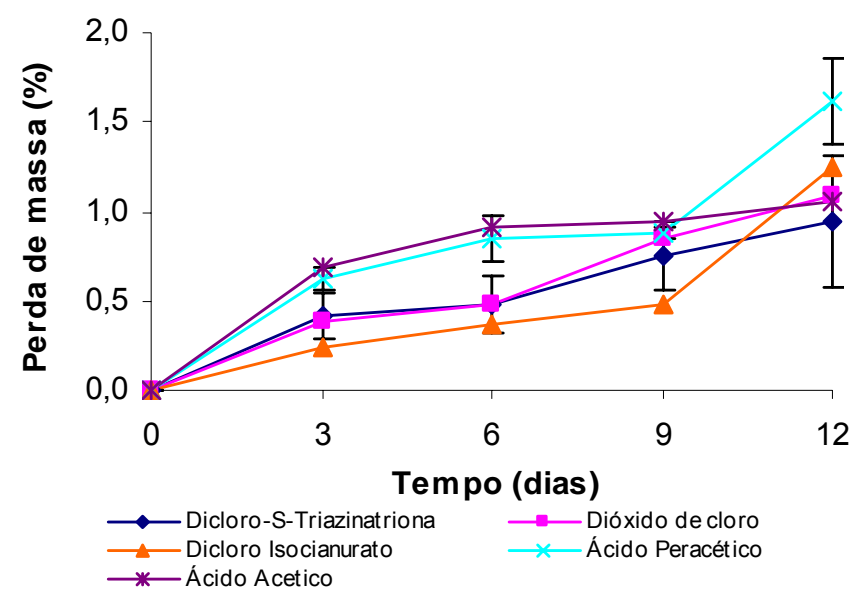

Figura 1 - Perda de massa de abóboras minimamente processadas tratadas com diferentes sanitizantes e armazenadas a $5^{\circ} \mathrm{C}$. Barras verticais representam o erro padrão da média

\section{Firmeza}

Os sanitizantes Ácido Acético e Ácido Peracético provocaram reduções na firmeza das abóboras minimamente processadas. Este fato pode ter ocorrido pelo baixo $\mathrm{pH}$ das soluções destes sanitizantes (Tabela 5) que pode ter afetado a parede celular das abóboras. Segundo Taiz \& Zeiger (2004), o afrouxamento da parede celular é intensificada em pH ácido, no alongamento das células. Assim, o pH ácido das soluções dos sanitizantes pode ter provocado o 
afrouxamento da parede celular das células da abóbora tendo como resultado a redução da firmeza.

Os sanitizantes Dicloro S-Triazinationa Sódica Diidratada, Dicloro Isocianurato de Sódio e Dióxido de Cloro mantiveram comportamento e valores semelhantes ao longo do período de armazenamento.

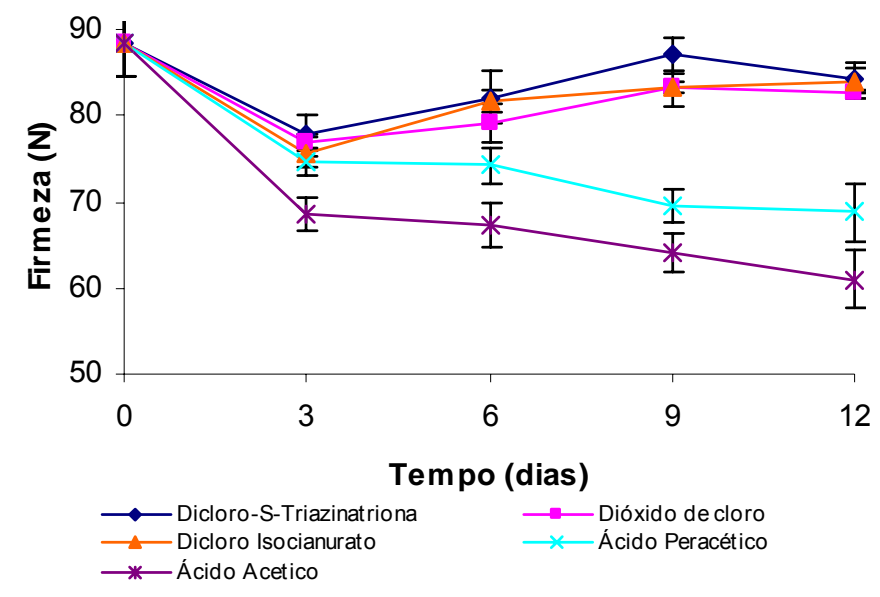

Figura 2 - Valores de firmeza (Newtons) de abóboras minimamente processadas tratadas com diferentes sanitizantes e armazenadas a $5^{\circ} \mathrm{C}$. Barras verticais representam o erro padrão da média

Tabela 5. Valores de $\mathrm{pH}$ das soluções dos sanitizantes em água destilada a $5^{\circ} \mathrm{C}$

\begin{tabular}{ll}
\hline Sanitizante & $\mathbf{p H}$ \\
\hline Dicloro S-Triazinationa Sódica Diidratada & 6,24 \\
Dicloro Isocianurato de Sódio Diidratada & 5,65 \\
Dióxido de Cloro & 9,98 \\
Ácido Peracético & 3,62 \\
Ácido Acético & 2,98
\end{tabular}

\section{Sólidos solúveis}

Não houve diferença significativa nos teores de sólidos solúveis entre os tratamentos, em nenhum dos dias de análise. A tendência de redução dos teores de sólidos solúveis é devido ao consumo dos açúcares na respiração de produto. 


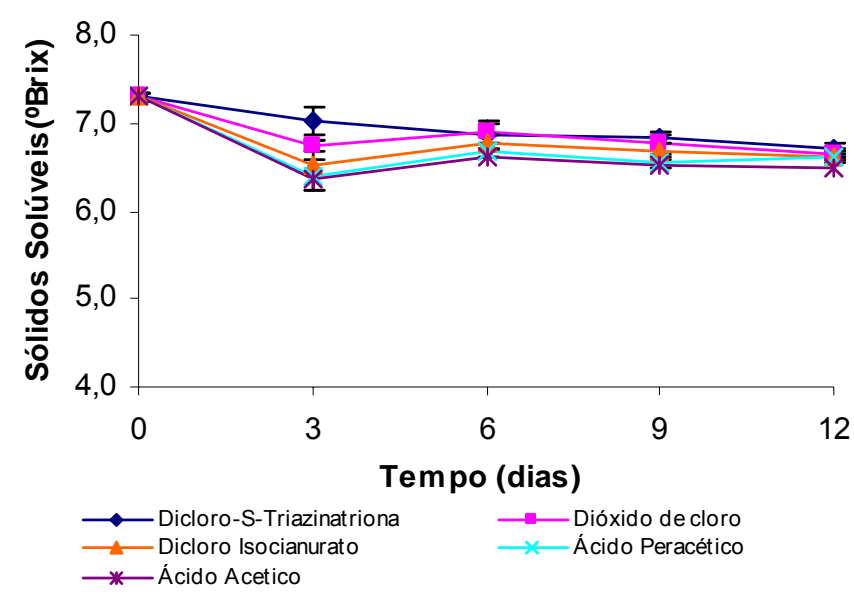

Figura 3 - Teores de sólidos solúveis ( ${ }^{\circ}$ Brix) de abóboras minimamente processadas tratadas com diferentes sanitizantes e armazenadas a $5^{\circ} \mathrm{C}$. Barras verticais representam o erro padrão da média

\section{Acidez}

O Ácido Acético, devido a sua natureza (baixo pH - Tabela 5), manteve a acidez das abóboras mais alta, entre 0,076 a 0,085\%, porém constante, desde o início até o último dia de armazenamento. Os demais sanitizantes mantiveram os valores de acidez constantes e próximos durante todo o período de armazenamento. De acordo com Beuchat \& Golden (1989), o mecanismo de atuação dos ácidos orgânicos pode estar diretamente relacionado com a redução do $\mathrm{pH}$ no interior das células. 


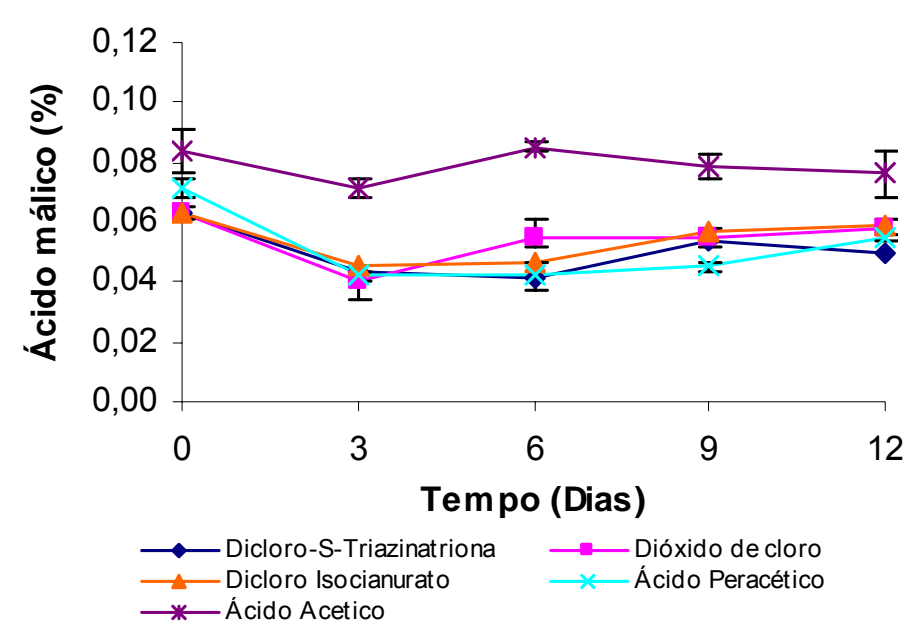

Figura 4 - Valores de acidez titulável (\% ácido málico) de abóboras minimamente processadas tratadas com diferentes sanitizantes e armazenadas a $5^{\circ} \mathrm{C}$. Barras verticais representam o erro padrão da média

\section{Ácido Ascórbico}

Segundo Lee \& Kader (2000) a vitamina C é definida como um termo genérico para todos os compostos que apresentam a atividade biológica semelhante ao L-ácido ascórbico (AA), sendo o AA é a principal forma biologicamente ativa da vitamina $\mathrm{C}$, mas existe ainda $\mathrm{O}$ ácido Ldehidroascórbico (DHA), um produto da oxidação do $A A$, que também exibe atividade biológica.

O tratamento com o Ácido Acético ocasionou uma maior redução nos teores de ácido ascórbico, sendo seguido do tratamento com Ácido Peracético (Figura 5). Embora Klein (1987) afirme que a vitamina C é estável em pH ácido, a redução nos teores de ácido ascórbico nos tratamentos com Ácido Acético e Ácido Peracético deve-se provavelmente, ao maior consumo desde composto ocasionado pelo estresse provocado nas membranas e na parede celular como mostra a Figura 2 pela maior perda de firmeza. Segundo Elliot (1999), a vitamina C é considerada uma "vitamina antioxidante", porque atua como inibidora de danos das células causados pelas espécies reativas de oxigênio. 


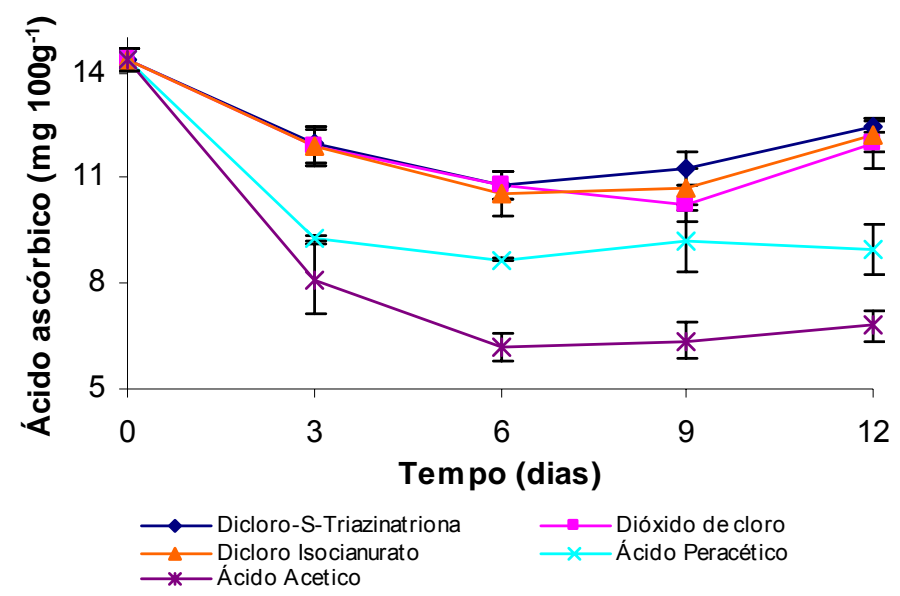

Figura 5 - Teores de ácido ascórbico $\left(\mathrm{mg} 100 \mathrm{~g}^{-1}\right)$ de abóboras minimamente processadas tratadas com diferentes sanitizantes e armazenadas a $5^{\circ} \mathrm{C}$. Barras verticais representam o erro padrão da média

\section{Carotenóides totais}

Os tratamentos com os sanitizantes Dicloro S-Triazinationa Sódica Diidratada, Dicloro Isocianurato de Sódio e Dióxido de Cloro mantiveram os teores de carotenóides totais entre 115,61 e $107 \mu \mathrm{g} \mathrm{g}^{-1}$, não apresentando diferença significativa em todos os dias de análises (Figura 6). Já os tratamentos com Ácido Acético e Ácido Peracético tiveram reduções drásticas nos teores de carotenóides totais. Isso foi devido, provavelmente aos pHs muito reduzidos das soluções dos sanitizantes (Tabela 5). Klein (1897) afirma que o $\beta$-caroteno é muito instável em pHs baixos. Como a abóbora possui, em sua maioria, $\beta$-caroteno (Rodrigues-Amaya, 2001), a imersão dos pedaços de abóboras nas soluções de sanitizantes, cujo os pHs eram baixos, ocasionou maiores perdas nos teores de carotenóides.

Considerando-se que os carotenóides são responsáveis pela cor alaranjada das abóboras, a redução nos teores destes compostos, também se refletiu na perda da coloração alaranjada tanto na cromaticidade ( $\left.C^{*}\right)$ (Figura 8) quanto no ângulo de cor (Figura 9), além de torna-las mais esbranquiçadas ao verificar-se o aumento nos valores de luminosidade (Figura 7). 


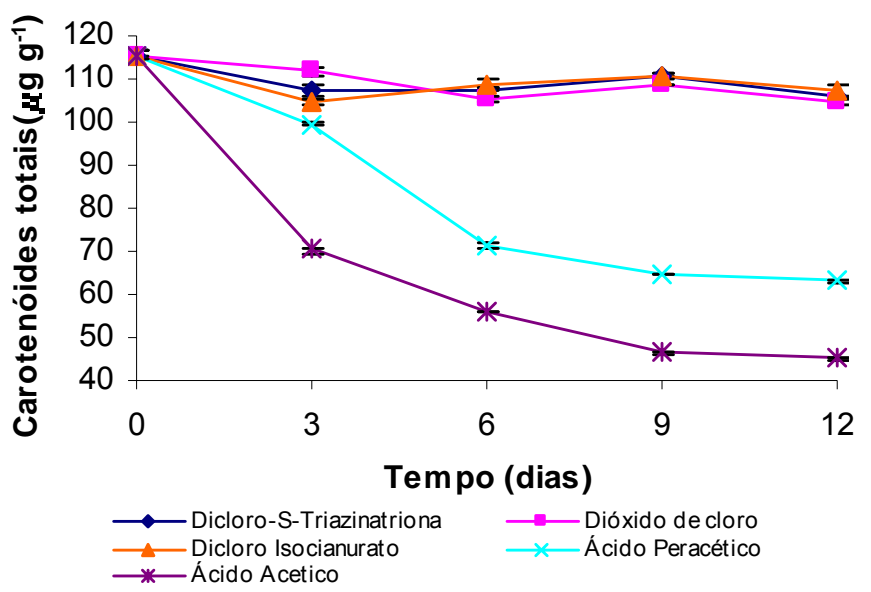

Figura 6 - Teores de carotenóides totais $\left(\mu \mathrm{g} \mathrm{g}^{-1}\right)$ de abóboras minimamente processadas tratadas com diferentes sanitizantes e armazenadas a $5^{\circ} \mathrm{C}$. Barras verticais representam o erro padrão da média

\section{Cor}

Houve um aumento nos valores luminosidade nos tratamentos com Ácido Acético sendo seguido pelo tratamento com Ácido Peracético. Esse aumento indica que as amostras eram mais claras (brancas), pois a luminosidade possui uma escala de 0 a 100 onde 0 é preto e 100 é branco. Esse esbranquiçamento é devido, em parte, à perda de água, afinal provoca a formação de uma camada desidratada ao redor dos pedaços de abóboras. Outro fato que contribuiu para o esbranquiçamento foi a perda de carotenóides totais (Figura 6) provocada pelo baixo $\mathrm{pH}$ das soluções dos sanitizantes. 


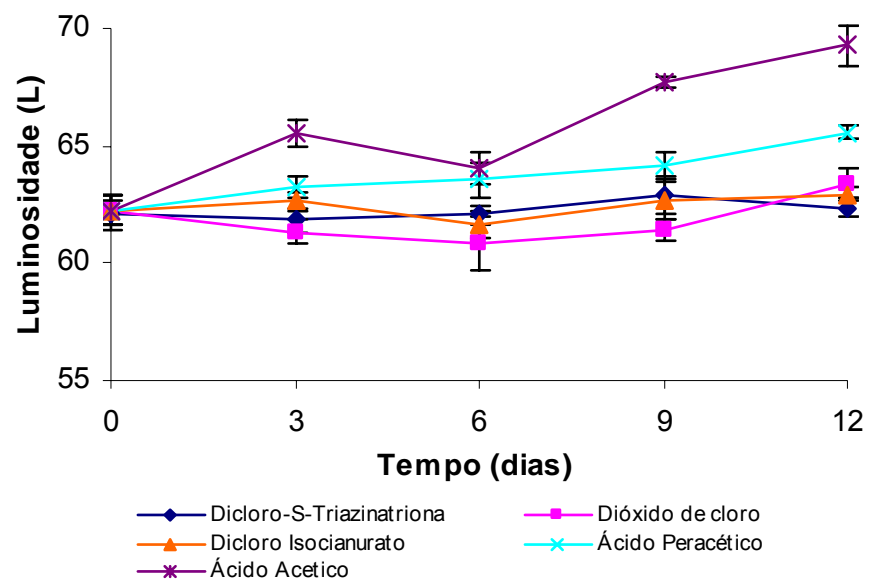

Figura 7 - Valores de luminosidade $(L)$ de abóboras minimamente processadas tratadas com diferentes sanitizantes e armazenadas a $5^{\circ} \mathrm{C}$. Barras verticais representam o erro padrão da média

A redução nos teores de carotenóides totais também afetou os valores de cromaticidade $\left(C^{*}\right)$ que apresentou uma redução dos seus valores nos tratamentos com Ácido Acético e Ácido Peracético (Figura 8). Essa redução indica que as abóboras perderam a intensidade da cor laranja devido a redução nos teores de carotenóides totais.

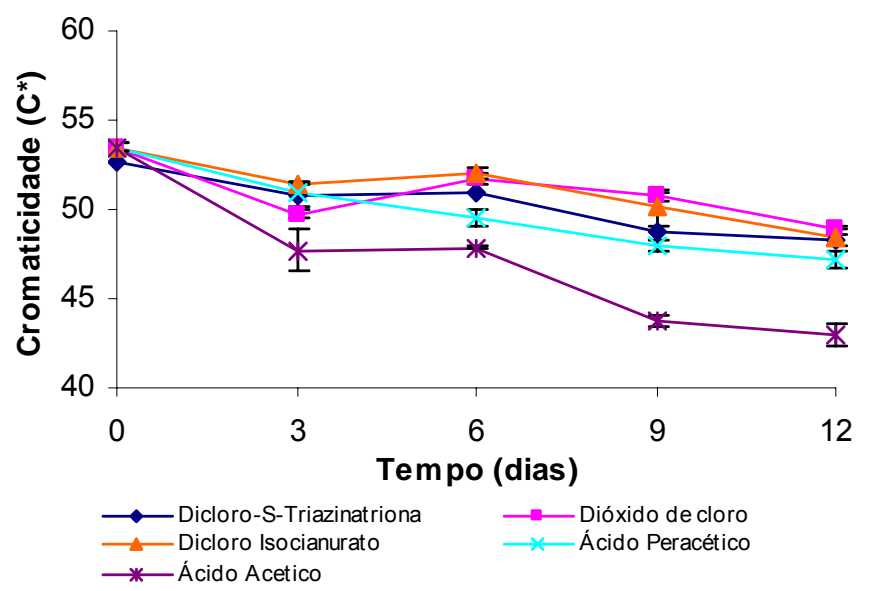

Figura 8 - Valores de cromaticidade $\left(C^{*}\right)$ de abóboras minimamente processadas tratadas com diferentes sanitizantes $\mathrm{e}$ armazenadas a $5^{\circ} \mathrm{C}$. Barras verticais representam o erro padrão da média 
As perdas de carotenóides totais pelos tratamentos com Ácido Acético e Peracético, interferiram também no ângulo de cor. O aumento nos valores do ângulo de cor mostram que as abóboras ficaram mais amareladas perdendo a cor alaranjada.

Os demais tratamentos não apresentaram diferenças entre si nos dias de análises e ao longo do período de armazenamento, para os valores de luminosidade, cromaticidade e ângulo de cor.

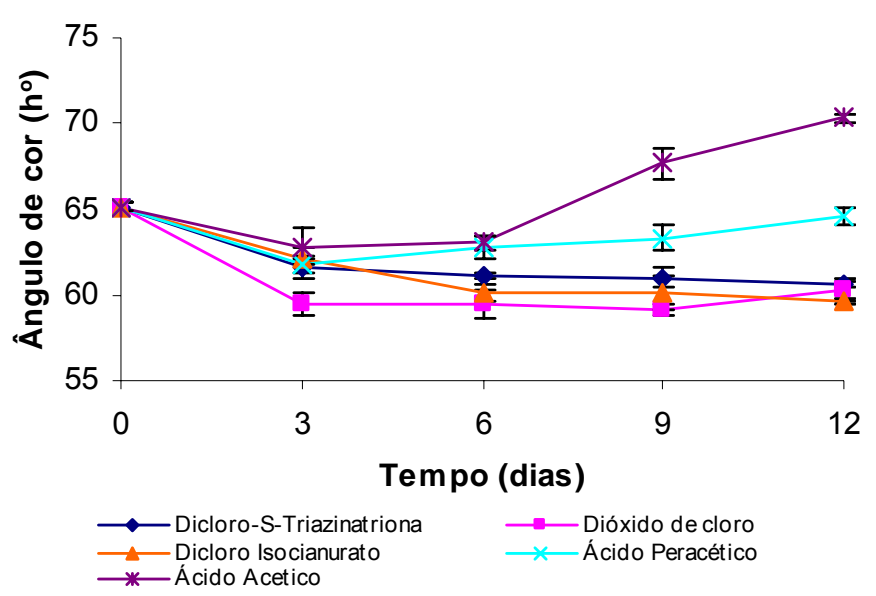

Figura 9 - Valores de ângulo de cor $\left(\mathrm{h}^{\circ}\right)$ de abóboras minimamente processadas tratadas com diferentes sanitizantes e armazenadas a $5 \pm 1{ }^{\circ} \mathrm{C}$. Barras verticais representam o erro padrão da média

Todos os sanitizantes foram eficientes na redução de contagem de bactérias psicrotróficas, sendo o Dicloro Isocianurato de Sódio o que apresentou melhores resultados. Embora o Ácido Acético tenha sido eficiente também na redução da contagem de bactérias psicrotróficas, este sanitizante provocou amolecimento das abóboras, além das maiores perdas nos teores de ácido ascórbico e carotenóides totais que ocasionou a perda da coloração. Esses fatos contribuem para a diminuição da qualidade do produto.

Ao contrário do observado em abóboras, Fantuzzi (1999) observou, em repolhos minimamente processados, uma redução significativa da microbiota aeróbia mesófila nas amostras sanitizadas com $1 \%$ de ácido acético sem causar danos aparentes na textura. 
Todo os sanitizantes, também, tiveram uma boa eficácia na eliminação dos coliformes totais e coliformes a $45^{\circ} \mathrm{C}$, pois na matéria-prima a contagem

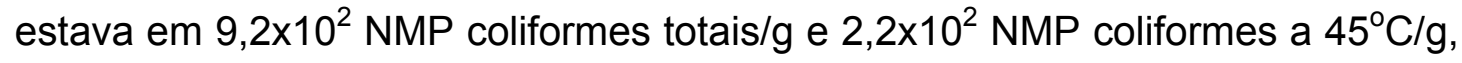
enquanto que as amostras de todos os sanitizantes analisadas logo após a sanitização indicavam ausência para ambas bactérias. Esses resultados colocam o produto dentro das especificações exigidas pela legislação na forma da resolução RDC $n^{\circ} 12$ da ANVISA que permite um máximo de $10^{2} \mathrm{NMP}$ de coliformes da $45^{\circ} \mathrm{C} / \mathrm{g}$, em hortaliças in natura.

Os sanitizantes Dicloro S-Triazinationa Sódica Diidratada, Dicloro Isocianurato de Sódio e Dióxido de Cloro não interferiram nas características qualitativas e nutricionais das abóboras minimamente processadas.

\subsection{Conclusões}

- Todos os sanitizantes foram eficientes para redução da contagem de bactérias psicrotróficas e na eliminação de coliformes totais de coliformes a $45^{\circ} \mathrm{C}$, mantendo as abóboras minimamente processadas dentro da legislação existente no país.

- Embora o sanitizantes Ácido Acético e Ácido Peracético sejam eficientes na redução da carga microbiana das abóboras minimamente processadas, o caráter ácido (baixo $\mathrm{pH}$ ) das soluções interferiu negativamente na qualidade das abóboras. 


\section{MÉTODOS COMBINADOS PARA PROCESSAMENTO MÍNIMO DE ABÓBORA}

\section{Resumo}

Frutos de abóbora, cv. Canhão, foram minimamente processadas e conservadas de acordo com o fluxograma obtido a partir dos estudos anteriores. As etapas de processamento mínimo constaram de: pré-lavagem, desinfecção inicial, período de descanso $\left(16 \mathrm{hs}\right.$ a $\left.10^{\circ} \mathrm{C}\right)$, corte inicial, retirada das sementes, descascamento, corte em meia-rodela ou cubos, sanitização (Dicloro Isocianurato de Sódio Diidratada), drenagem, pesagem (270g),

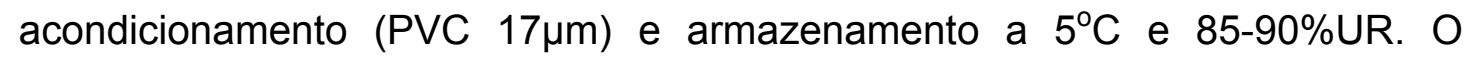
armazenamento realizou-se durante 24 dias efetuando-se -se análises físicas, químicas, físico-químicas e microbiológicas. Ambos os cortes utilizados no fluxograma apresentaram comportamentos semelhantes em relação às variáveis analisadas, inclusive às microbiológicas. Isto mostrou que pode-se utilizar ambos os tipos de corte, o que confere um maior aproveitamento de todas as partes do fruto. $O$ novo fluxograma de preparo garante a segurança do produto até 12 dias, o que foi determinado através das avaliações microbiológicas. Constatou-se a ausência de Salmonella e crescimento de coliformes totais e coliformes a $45^{\circ} \mathrm{C}$ durante o armazenamento.

Palavra-chave: Cucurbita moschata Duch., processamento mínimo, fluxograma, microbiologia, carotenóides. 


\section{COMBINED METHODS FOR THE MINIMAL PROCESSING OF SQUASH}

\section{Summary}

Squash fruit, cv. Canhão, were minimally processed and stored according to the flowchart established from results obtained in previous experiments. The following processing operations were effectuated:initial wash, desinfection, retire period (16 hs at $10^{\circ} \mathrm{C}$ ), initial cut, seeds remove, peeling, cut (middle-circle or cube), sanitization (Sodium Diclorine Isocianurate Dihidratade), drainage, weighing $(270 \mathrm{~g})$, packing (PVC $17 \mu \mathrm{m})$ and storage in $5^{\circ} \mathrm{C}$ and $85-90 \% \mathrm{RH}$. The squashes were storage during 24 days and physical, chemical, physicochemical and microbiological were evaluated. The cut types used in the flowchart showed a similar behavior in relation to the analyzed variables, include microbiological analyses. The use of these cut types permit a utilization of all fruit in the processing. The microbiological analyses of new flowchart ensure a food safe up to 12 days. It was no verified total coliform, coliforms at $45^{\circ} \mathrm{C}$ and Salmonella during storage.

Key-words: Cucurbita moschata Duch., flowchart, microbiology, carotenoids.

\subsection{Introdução}

Nos últimos tempos a sociedade tem enfatizado a necessidade de consumo de frutas e hortaliças frescas, buscando-se uma dieta mais saudável ao mesmo tempo em que há uma demanda crescente de alimentos mais convenientes, frescos, menos processados e prontos para o consumo, em detrimento dos alimentos enlatados ou congelados (Souza, 2001). Por este motivo, a utilização de produtos hortícolas minimamente processados está aumentando bastante, sobretudo em razão do interesse que os produtos naturais e convenientes tem despertado no consumidor (Durigan \& Sargent, 1999). 
A fisiologia de vegetais minimamente processados é corresponde a fisiologia de tecidos vegetais danificados (Brecht, 1995). Assim, o comportamento dos tecidos desses produtos é típico ao observado em tecidos de plantas que foram danificadas ou expostas a condições de estresse. Este comportamento inclui respiração aumentada e produção de etileno e, em alguns casos, indução do processo de cicatrização (Abe \& Watada, 1991). Segundo Brecht (1995), outras conseqüências de natureza química e física como o escurecimento oxidativo, a oxidação de lipídios e aumento da perda de massa, podem ser citados. Segundo Varoquaux \& Wiley (1997), isso é devido a descompartimentalização celular, provocada durante o processamento, que possibilita o contato de enzimas e substratos que originam tais modificações bioquímicas. Por isso, o produto minimamente é mais perecível que o produto inteiro.

Adicionalmente o processamento mínimo causa o aumento em superfície pelo corte, dano e disponibilidade de nutrientes, provendo condições que aumentam o número e os tipos de microrganismos que aí se desenvolvem. Além disso, o aumento da manipulação desses produtos possibilita a contaminação por patógenos. (Rosa \& Carvalho, 2000).

O controle estrito da temperatura, associado à utilização criteriosa de embalagens e de tecnologia de modificação da atmosfera são métodos eficazes para o controle de processos metabólicos descritos anteriormente e que contribuem para a redução da qualidade final de produto (Moretti, 2004).

Durante o processo de preparo dos produtos minimamente processados, a etapa de sanitização é essencial, como forma de minimizar a deterioração e manter a qualidade de produto (Brackett, 1992; Hurst, 1995).

Um dos principais problemas da comercialização de abóboras é a grande dimensão e peso destas, dificultando seu manuseio e conservação (Habibunnisa et al., 2001).

Com o objetivo de ampliar o conhecimento, atender as novas demandas do mercado e aumentar as alternativas tecnológicas, este trabalho se propôs a estudar o fluxograma de preparo específico desenvolvido a partir de testes 
experimentais anteriores e verificar seu efeito na qualidade de abóboras minimamente processadas.

\subsection{Material e Métodos}

As abóboras maduras (Cucurbita moschata Duch.), cv. Canhão, forma adquiridas de um produtor da região de Tupã-SP e trazidas ao Laboratório de Pós-Colheita do Departamento de Produção Vegetal, da ESALQ/USP. Anteriormente, as abóboras sofreram uma pré-seleção, sendo selecionados os frutos sem injúrias e uniformes quanto ao tamanho, cor da casca e formato. Ao chegarem ao laboratório os frutos foram lavados com detergente e em água corrente, para retirada da sujeira grosseira. Em seguida, as abóboras sofreram uma desinfecção inicial com imersão em solução contento $10 \mathrm{ppm}$ de cloro ativo. Após, as abóboras foram colocadas em câmara fria a $10 \pm 1^{\circ} \mathrm{C} \mathrm{com} 85$ 90\% UR, onde permaneceram por 16 horas.

O processamento foi realizado em câmara fria a $10 \pm 1^{\circ} \mathrm{C}$, utilizando-se roupas apropriadas (botas, avental, touca, máscara e luvas). A água utilizada no processamento foi destilada e refrigerada a $5^{\circ} \mathrm{C}$.

A primeira etapa do processamento consistiu em corte em rodelas de $3,0 \mathrm{~cm}$ de espessura, utilizando-se faca de inoxidável afiada; remoção das sementes e parte esponjosa (com auxílio de colher) e cortes finais. Após os cortes, os pedaços foram lavados em água destilada (para retira de excesso de suco celular), sanitizados com solução de sanitizante em concentração de $10 \mathrm{ppm}$ de cloro ativo, tendo como princípio ativo o Dicloro Isocianurato de Sódio. Em seguida, os pedaços foram deixados em escorredores domésticos para retirada do excesso de água. Os pedaços foram pesados $(270 \mathrm{~g})$ e acondicionados em bandejas de poliestireno expandido e cobertos com PVC $17 \mu \mathrm{m}$. As embalagens foram armazenadas a $5 \pm 1^{\circ} \mathrm{C}$ e $85-90 \%$ UR.

Detalhes do processamento mínimo podem ser encontrados no capítulo 3 , nas páginas 20 e 21 . 
Como os tipos de corte em meia-rodela e cubos foram os que apresentaram menores alterações nas características qualitativas e crescimento microbiano mais lento, decidiu-se por avaliar os dois tipos de corte, pois embora o corte em meia-rodela tenha se comportado um pouco melhor que o corte em cubos em alguns das variáveis estudadas anteriormente. O corte em meiarodela tem algumas limitações como a não possibilidade do aproveitamento da região onde se alojam as sementes, limitando-se somente à região do "pescoço" da abóbora, resultando em aumento muito grande de perdas. Por outro lado, corte em cubos pode ser realizado em todas as partes da abóbora, possibilitando dessa maneira um maior aproveitamento do fruto.

Foi escolhida temperatura de $5^{\circ} \mathrm{C}$ para o armazenamento das abóboras, considerando que é economicamente mais viável que $1^{\circ} \mathrm{C}$. Além disso, na temperatura de $5^{\circ} \mathrm{C}$ as abóboras tiveram comportamento muito próximo das abóboras mantidas a $1^{\circ} \mathrm{C}$, tanto na parte qualitativa quanto na parte microbiológica.

O armazenamento foi por período de 24 dias, sendo feitas análises nos dias $0,3,6,9,12,15,18,21$ e 24 para as avaliações físicas, químicas e físicoquímicas e análises no $0,6^{\circ}, 12^{\circ}, 18^{\circ}$ e $24^{\circ}$ dia de armazenamento, para as avaliações microbiológicas.

\section{Análises físicas, químicas e físico-químicas}

As determinações realizadas foram: a) Perda de massa (\%), através da diferença entre a massa inicial e final da repetição; b) Firmeza (Newtons), com auxílio de penetrômetro manual; c) Coloração $\left(L, C^{*}\right.$ e $\left.h^{\circ}\right)$, com auxílio de colorímetro (Minolta); d) Teor de sólido solúveis ( ${ }^{\circ}$ Brix), utilizando um refratômetro (Atago); e) Acidez titulável (\%), através de titulação com $\mathrm{NaOH}$ $0,1 \mathrm{~N} ; \mathrm{f})$ Teor de ácido ascórbico $\left(\mathrm{mg} 100 \mathrm{~g}^{-1}\right)$, obtida através de titulação com DCFI; g) Teor de carotenóides totais $\left(\mu \mathrm{g} \mathrm{g}^{-1}\right)$, com auxílio de espectrofotômetro (FEMTO-700 Plus). 
Maiores detalhes das análises podem ser encontradas no capítulo 3, nas páginas 22 a 25.

\section{Análises microbiológicas}

As análises microbiológicas realizadas foram: contagem de bactérias psicrotróficas (UFC/g), pelo método do plaqueamento em profundidade com diluições de $10^{-1}$ a $10^{-3}$; contagem de coliformes fecais (NMP), pela técnica de Tubos Múltiplos, utilizando as diluições de $10^{-1}$ a $10^{-3}$; e detecção de Salmonella (ausência ou presença), com auxílio de kits ('1-2 Test' - Biocontrol/USA).

As análises microbiológicas realizadas estão descritas com maiores detalhes no capítulo 3, nas páginas 25 a 28 .

\section{Delineamento experimental}

O delineamento experimental utilizado foi inteiramente casualizado em fatorial $2 \times 9$, com tipos de corte em dois níveis (meia-rodela e cubo) e tempo em nove níveis $(0,3,6,9,12,15,18,21$ e 24 dias). Foram utilizadas quatro repetições, sendo cada uma composta com bandejas com $270 \mathrm{~g}$ de abóbora minimamente processada. Para a caracterização do lote experimental (tempo zero), quatro amostras foram analisadas logo após o processamento mínimo do produto. Os resultados obtidos das análises físicas químicas e físico-químicas foram submetidos à análise do erro padrão. As diferenças entre dois tratamentos maior que a soma dos erros padrões foram consideradas significativas $(P<0,05)$ (Moretti et al., 2002).

Para avaliação dos aspectos microbiológicos os resultados foram expressos em UFC/g de produto para bactérias psicrotróficas, NMP/g para coliformes totais e presença ou ausência de Salmonella em $25 \mathrm{~g}$ de produto. 


\subsection{Resultados e Discussão}

\section{Análises físicas, químicas e físico-químicas}

A perda de massa aumentou para os dois tipos de corte, sendo que o corte em cubos mostrou maiores perdas até o $12^{\circ}$ dia de armazenamento. Após esse período, os valores de perda de massa foram semelhantes (Figura 1). Segundo Carvalho \& Lima (2000), a perda de massa é devido à perda de umidade e de material de reserva pela transpiração e respiração, respectivamente.

Embora tenha havido uma perda de massa crescente, os valores ficaram muito abaixo dos valores críticos indicados por Finger \& Vieira (1997), que são de 5 a 10\%, ficando em torno de 0,7\% para ambos os cortes, após 24 dias de armazenamento (Figura 1).

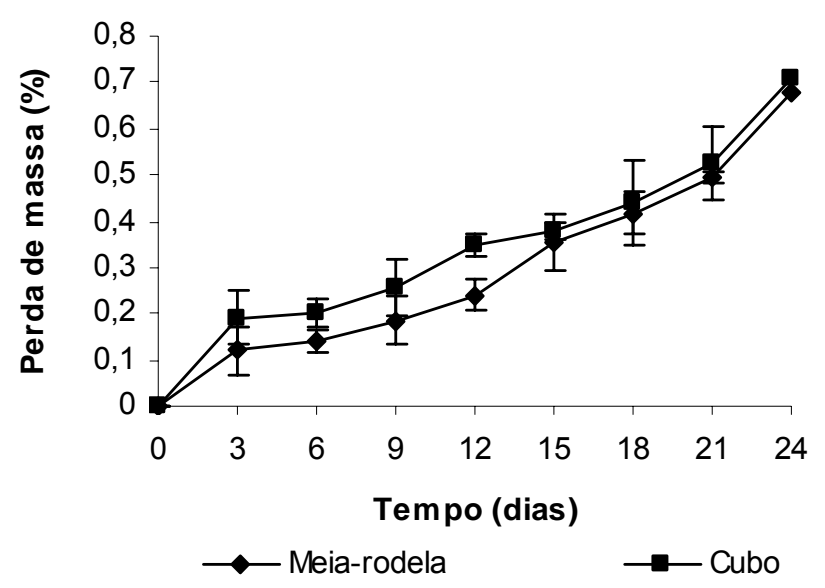

Figura 1 - Perda de massa (\%) de abóboras minimamente processadas em dois tipos de corte e armazenadas a $5^{\circ} \mathrm{C}$. Barras verticais representam o erro padrão da média

A firmeza manteve praticamente constante até $012^{\circ}$ dia de armazenamento para ambos os cortes, ficando em torno de $78 \mathrm{~N}$ para meiarodela e $76 \mathrm{~N}$ para os cubos (Figura 2). Isso mostra que a embalagem e a temperatura de armazenamento foram eficientes para evitar a perda de turgescência das abóboras minimamente processadas. 
As mudanças de firmeza ocorridas após o $15^{\circ}$ dia de armazenamento podem ser devido ao aumento do número de microrganismos (Tabela 1), estando presentes, entre eles, bactérias deteriorantes, além também da presença de fungos causadores de podridão.

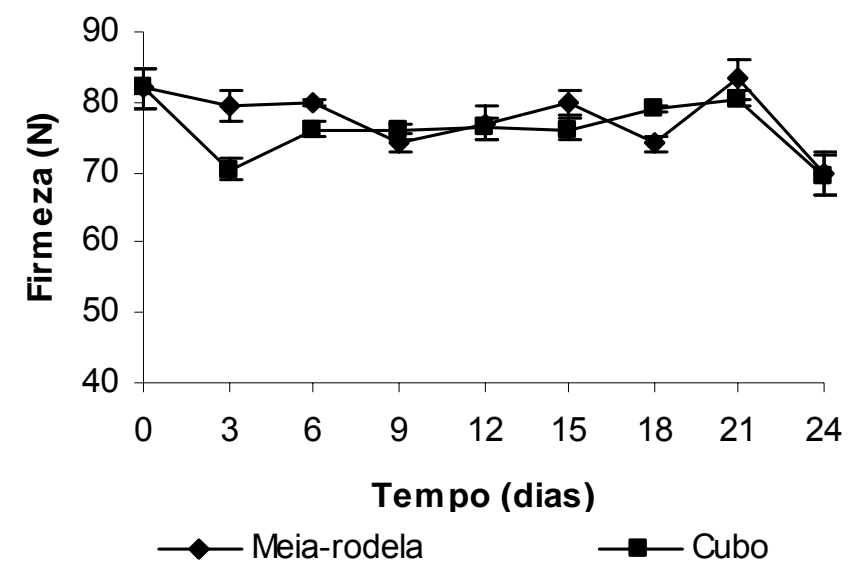

Figura 2 - Valores de firmeza (Newtons) de abóboras minimamente processadas em dois tipos de corte e armazenadas a $5^{\circ} \mathrm{C}$. Barras verticais represenpam o erro padrão da média

Os dois tipos de corte mostraram uma leve queda nos teores de sólidos solúveis até o $21^{\circ}$ dia de armazenamento, sendo que, após esse período, houve um brusco decréscimo (Figura 3). Vitti (2003) avaliando um fluxograma para processamento mínimo de beterraba notou que os teores de sólidos solúveis ficaram constantes em torno de $5,2^{\circ}$ Brix, até $010^{\circ}$ dia de armazenamento a $5^{\circ} \mathrm{C}$.

O decréscimo brusco nos teores de sólidos solúveis após o $21^{\circ}$ dia de armazenamento pode ter ocorrido devido à proliferação de microrganismos deteriorantes, pois no $21^{\circ}$ as abóboras apresentavam-se muito deterioradas. 


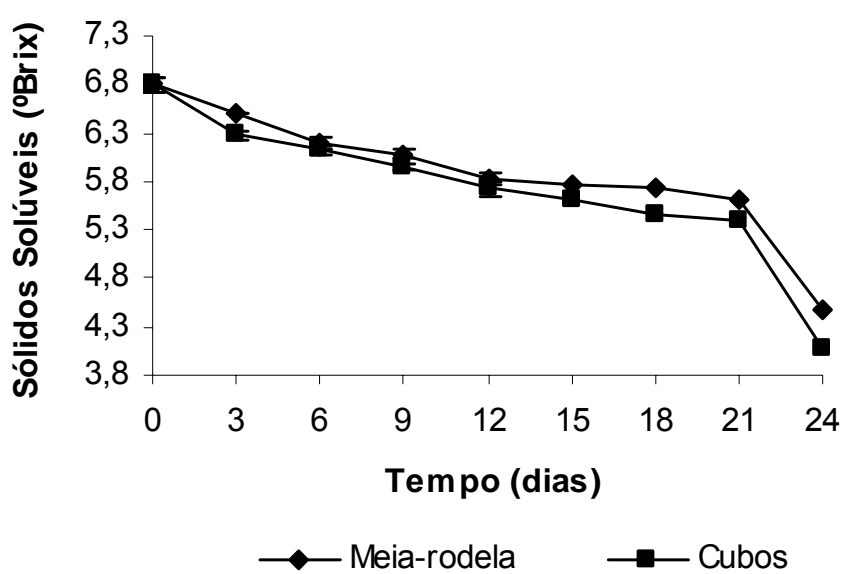

Figura 3 - Teores de sólidos solúveis ( ${ }^{\circ}$ Brix) de abóboras minimamente processadas em dos tipos de corte e armazenadas a $5^{\circ} \mathrm{C}$. Barras verticais representam o erro padrão da média

Foram verificadas algumas oscilações nos teores de acidez em função do tipo corte (Figura 4), sendo que os valores variaram de 0,07 a 0,1\%de ácido málico.

As alterações ocorridas no final do armazenamento pode ter sido provocadas pelo elevado número de microrganismos presentes, podendo estar presentes entres eles bactérias deteriorantes como Erwinia carotovora.

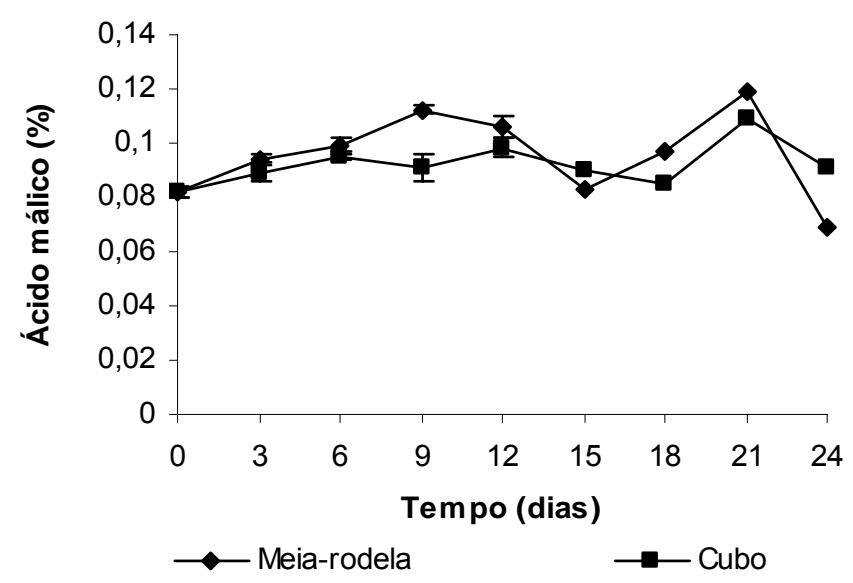

Figura 4 - Valores de acidez titulável (\% ácido málico) de abóboras minimamente processadas em dois tipos de corte e armazenadas a $5^{\circ} \mathrm{C}$. Barras verticais representam o erro padrão da média 
Para ambos os cortes, os teores de ácido ascórbico tiveram um decréscimo até o $6^{\circ}$ dia de armazenamento, ficando os valores constantes em torno de $7,2 \mathrm{mg} 100 \mathrm{~g}^{-1}$ até $18^{\circ}$ dia de armazenamento (Figura 5).

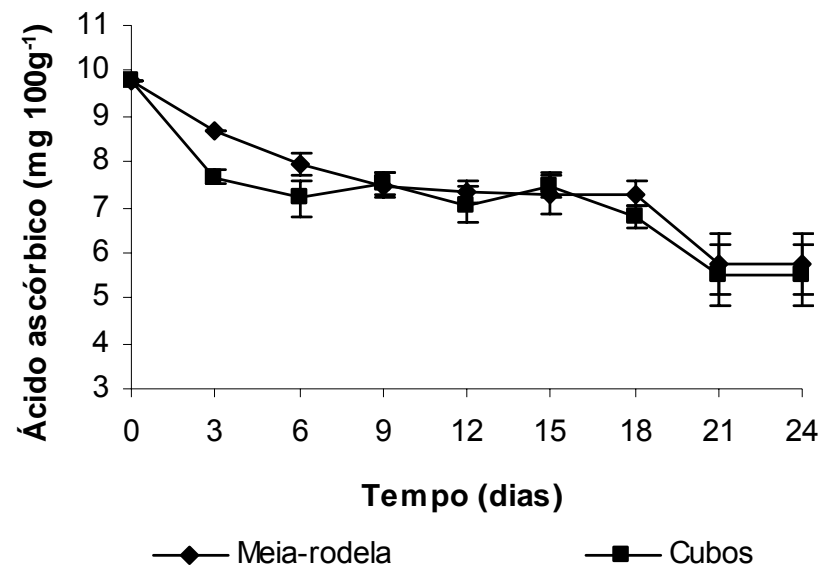

Figura 5 - Teores de ácido ascórbico $\left(\mathrm{mg} 100 \mathrm{~g}^{-1}\right)$ de abóboras minimamente processadas em dois tipos de corte e armazenadas a $5^{\circ} \mathrm{C}$. Barras verticais representam erro padrão da média

Os teores de carotenóides totais tiveram uma queda brusca até o $6^{\circ}$ dia de armazenamento, tendo um pequeno aumento no $9^{\circ}$ dia e voltando a cair após este período (Figura 6).

Segundo Elliott (1999) como o ácido ascórbico (pró-vitamina C) e os carotenóides (pró-vitamina A) são considerados compostos antioxidantes naturais, a redução nos teores de ácido ascóbico e carotenóides podem ter ocorrido na tentativa do vegetal proteger e recuperar suas células danificas pelos cortes. Parte dessa redução pode também ter sido provocada pela oxidação tanto do ácido ascórbico quanto dos carotenóides totais. Segundo Klein (1987), esses compostos são afetados por diversos fatores, como luz, oxigênio e temperatura. Aumentos nos teores de carotenóides totais podem ocorrer após a colheita (Rodiguez-Amaya, 2001). 


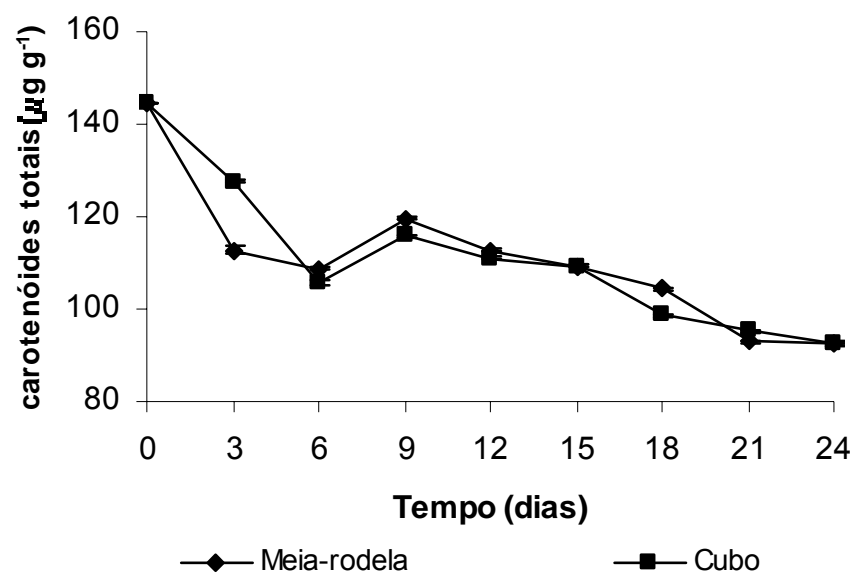

Figura 6 - Teores de carotenóides totais $\left(\mu \mathrm{g} \mathrm{g}^{-1}\right)$ de abóboras minimamente processadas em dois tipos de corte e armazenadas $5^{\circ} \mathrm{C}$. Barras verticais representam o erro padrão da média

Houve um aumento nos valores de luminosidade para ambos os cortes, até o $6^{\circ}$ dia. Após esse período os valores ficaram constantes.

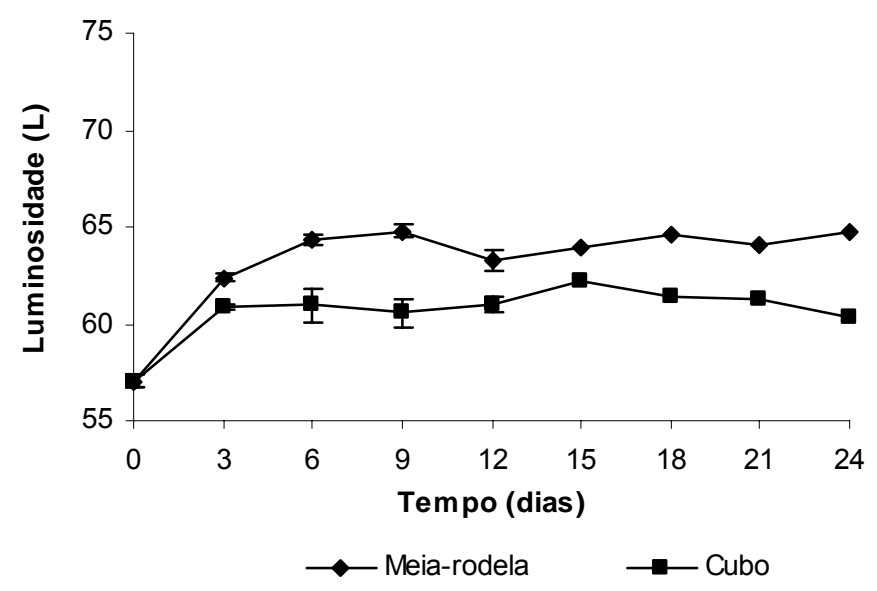

Figura 7 - Valores de luminosidade $(\mathrm{L})$ de abóboras minimamente processadas em dois tipos de corte e armazenadas a $5^{\circ}$. Barras verticais representam erro padrão da média

O corte em cubos manteve os valores de cromaticidade constantes, por volta de 53, e mais elevados durante o período de armazenamento. O corte em meia-rodela apresentou um leve decréscimo nos valores chegando a 49 no último dia de armazenamento (Figura 8). 


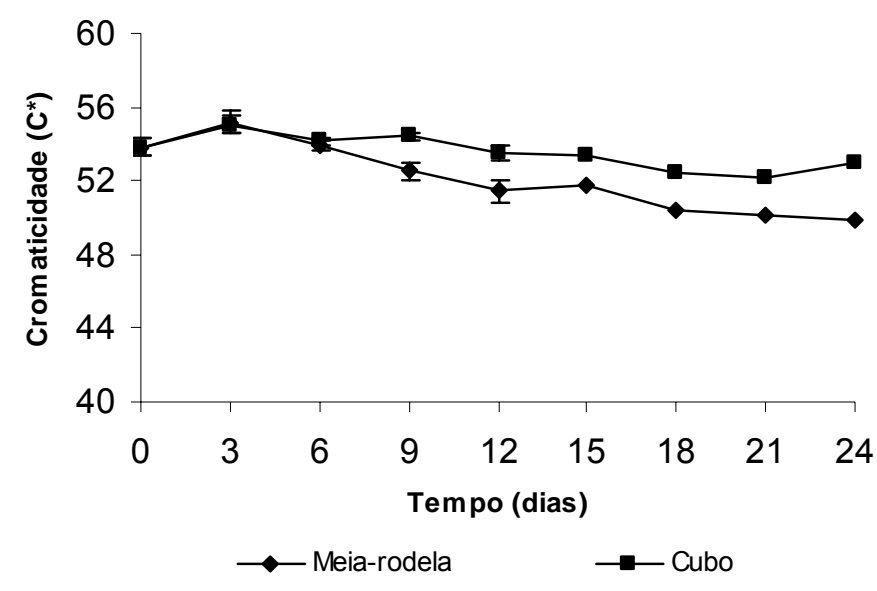

Figura 8 - Valores de cromaticidade $\left(C^{*}\right)$ de abóboras minimamente processadas em dois tipos de corte e armazenadas a $5^{\circ} \mathrm{C}$. Barras verticais representam o erro padrão da média

Os valores do ângulo de cor mantiveram constante durante todo o período de armazenamento, não apresentando diferenças entre os dois cortes (Figura 9)

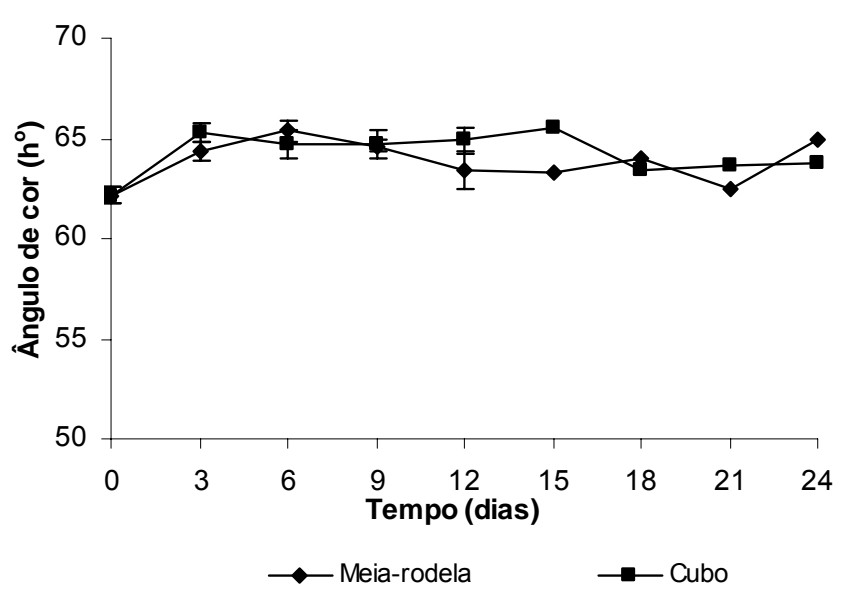

Figura 9 - Valores do ângulo de cor $\left(\mathrm{h}^{\circ}\right)$ de abóboras minimamente processadas em dois tipos de corte e armazenadas a $5^{\circ} \mathrm{C}$. Barras verticais representam o erro padrão da média

Pelas Figuras 7, 8 e 9 pode-se notar que os métodos combinados foram eficientes na manutenção da cor das abóboras minimamente processadas e na redução do esbranquiçamento das mesmas. 


\section{Análises microbiológicas}

Como não existe, no país, legislação específica que estabeleça um limite para o número de bactérias psicrotróficas, foi considerada como base o limite estabelecido por Morton (2001) para contagem de bactérias aeróbicas mesófilas em vegetais congelados e similares, sendo permitida para estes contagens de até $10^{5}-10^{6} \mathrm{UFC} / \mathrm{g}$. Neste sentido, ambos os cortes tiveram uma contagem de bactérias psicrotróficas limite no $12^{\circ}$ dia de armazenamento, embora o corte em meia-rodela apresentasse crescimento de bactérias pscicrotróficas mais lento no início, no $12^{\circ}$ dia as contagens foram muito próximas ao do corte em cubos (Tabela 1).

Embora no $18^{\circ}$ dia de armazenamento o corte em meia-rodela estivesse dentro do limite máximo estabelecido por Morton (2001), apresentando com contagem de $4,8 \times 10^{6} \mathrm{UFC} / \mathrm{g}$, seria arriscado liberar esse produto para 0 consumo, pois segundo Caruso \& Camargo (1984), quanto maior o número de microrganismos nos alimentos, maiores são as probabilidades de presença de patógenos e/ou deteriorantes. Além disso, nessas contagens os alimentos apresentavam deterioração por fungos e bactérias fitopatogênicas.

Sorhaung \& Stepaniak (1997) observaram alterações organolépticas e estruturais em queijos, causadas por enzimas proteolíticas de bactérias psicrotróficas, quando as contagens desses microrganismos no leite estavam entre $2,0 \times 10^{6}$ e $2,0 \times 10^{8} \mathrm{UFC} / \mathrm{g}$. Embora seja produto completamente diferente do leite, os mesmo processos podem estar ocorrendo nas abóboras minimamente processadas com relação às bactérias psicrotróficas. 
Tabela 1. Contagem total de bactérias psicrotróficas em abóboras minimamente processadas armazenadas a $5^{\circ} \mathrm{C}$ e $85 \pm 5 \%$ UR, utilizando-se a metodologia convencional (PCA)

Tratamentos Dias após corte

\begin{tabular}{llllll} 
& $\mathbf{0}$ & $\mathbf{6}$ & $\mathbf{1 2}$ & $\mathbf{1 8}$ & $\mathbf{2 4}$ \\
\hline Retalhos & $1,3 \times 10^{2}$ & $1,2 \times 10^{3}$ & $4,9 \times 10^{5}$ & $2,2 \times 10^{7}$ & $6,5 \times 10^{7}$ \\
Cubos & $6,0 \times 10$ & $4,7 \times 10^{2}$ & $3,2 \times 10^{5}$ & $4,8 \times 10^{6}$ & $3,9 \times 10^{7}$ \\
\hline
\end{tabular}

Os resultados obtidos representam a média aritmética das UFC /g de produto. As análises microbiológicas mostraram ausência de coliformes totais, coliformes a $45^{\circ} \mathrm{C}$ e Salmonella, em todos os dias de análise, para ambos os cortes.

Pela não existência, no país, de uma legislação específica para os vegetais minimamente processados, os resultados foram comparados com a resolução RDC n ${ }^{0} 12$ de 02 de janeiro de 2001 da Agência Nacional de Vigilância Sanitária (ANVISA) do Ministério de Saúde, que estabelece a ausência de Salmonella (em $25 \mathrm{~g}$ de produto) e permite um máximo de $10^{2} \mathrm{NMP}$ de coliformes da $45^{\circ} \mathrm{C} / \mathrm{g}$, em hortaliças in natura. Levando em consideração esta resolução, os resultados estão dentro dos limites estabelecidos pela legislação.

Pilon et al (2002) também obteve resultados semelhantes em cenouras minimamente processadas. A autora observou ausência de coliformes fecais e Salmonella durante todo o período de armazenamento, sendo observado que somente as bactérias psicrotróficas apresentaram aumento.

A ausência de coliformes a $45^{\circ} \mathrm{C} / \mathrm{g}$ e Salmonella, nas amostras analisadas, permite afirmar que os cuidados higiênico-sanitários tomados durante o processamento mínimo foram eficientes, enquadrando o produto nos padrões microbiológicos vigentes no país.

Conforme observado no presente estudo, o uso dos métodos combinados para elaboração de um fluxograma específico mostrou que tanto o corte em meia-rodela quanto em cubos podem ser utilizados, possibilitando dessa maneira o maior aproveitamento frutos de abóboras. O corte em meia- 
rodela provocou menor perda de massa, mas por outro lado causou aumento da luminosidade (indicando esbranquiçamento) e redução dos valores de chroma (indicando perda da intensidade de cor). O corte em cubos, embora tenha mostrado maior perda de massa, não provocou alterações na coloração e causou um menor aumento na luminosidade (indicando menor esbraquiçamento). Com relação aos outros parâmetros analisados os dois tipos de corte apresentaram comportamentos semelhantes não observando diferenças entre si. Os padrões microbiológicos obtidos estão de acordo com as normas estabelecidas pela ANVISA, mostrando que os cuidados de higiene tomados antes e durante o processamento mínimo e o sanitizante utilizado se enquadram na legislação. Esperava-se que, com os métodos combinados, as abóboras minimamente processadas pudessem ser armazenadas de 24 a 30 dias, porém devido às contagens microbianas e à deterioração, pôde-se verificar que as abóboras minimamente processadas podem ser armazenadas durante 12 dias sem causar maiores perdas na qualidade e tendo sua segurança garantida.

\subsection{Conclusões}

- Pode-se concluir que o fluxograma de preparo testado garante a segurança alimentar das abóboras durante 12 dias, sem perdas significativas na qualidade.

- Tanto o corte em meia-rodela quanto o corte em cubos podem ser utilizados no fluxograma de preparo das abóboras minimamente processadas, aumentando o aproveitamento de todas as partes do fruto da abóbora. 


\section{CONSIDERAÇÃO FINAL}

Apesar do grande potencial dos produtos minimamente processados, ainda existem muitos problemas na sua produção comercialização, tais como falte de legislação sanitária específica, normas de fabricação, tecnologias de produção, embalagens adequadas e uma boa cadeia de frio. Existe ainda a necessidade de estabelecer tipos de preparo e temperaturas adequadas de armazenamento que preservem a vida útil do produto por um período maior.

Diante de tantos desafios, este trabalho permitiu expor a possibilidade de se obter abóboras minimamente processadas, com boa qualidade, além de se estabelecer alguns parâmetros através das respostas fisiológicas, qualitativas e microbiológicas encontradas neste produto.

Pode se verificar que o fluxograma de preparo testado garantiu um produto saudável e seguro durante 12 dias, minimizando problemas com esbranquiçamento dos tecidos expostos.

É sugerido para futuros experimentos, o estudo do uso de atmosfera modificada ativa para visando aumentar a qualidade e a vida de prateleira das abóboras minimamente processadas. 
ANEXOS 
ANEXO A - Seqüência de processamento mínimo de abóbora
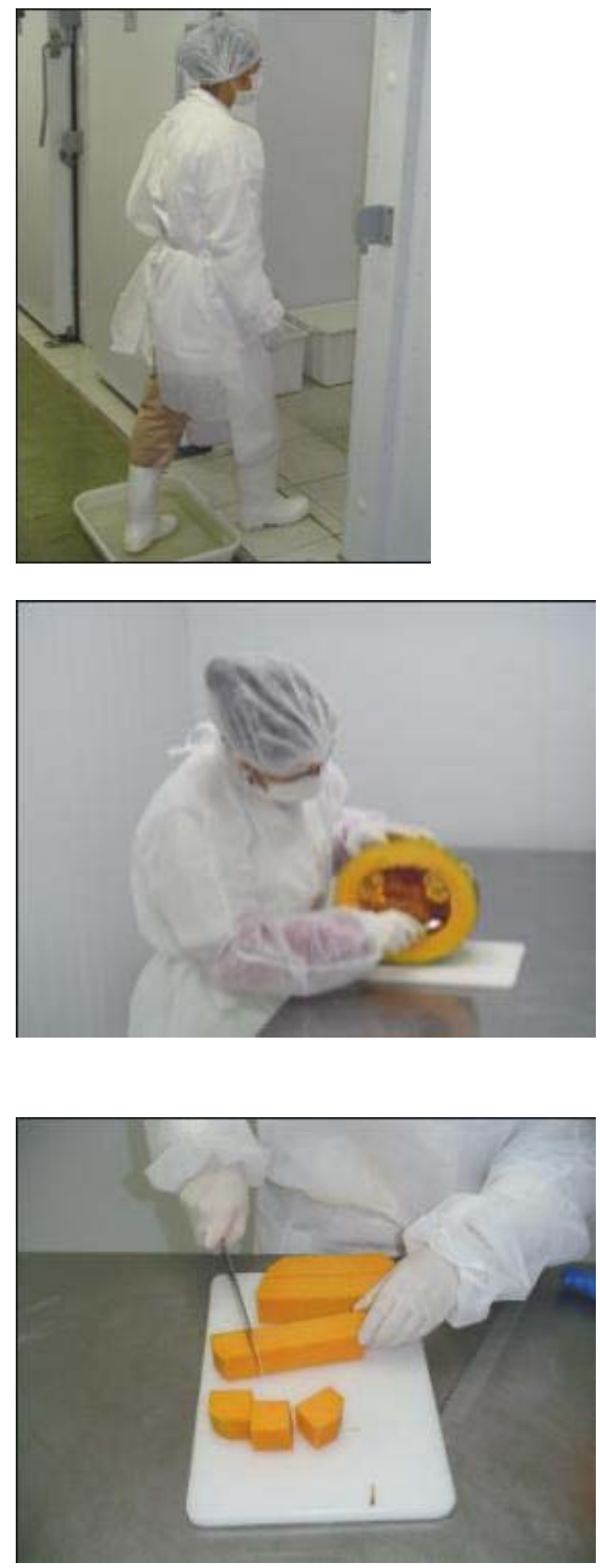
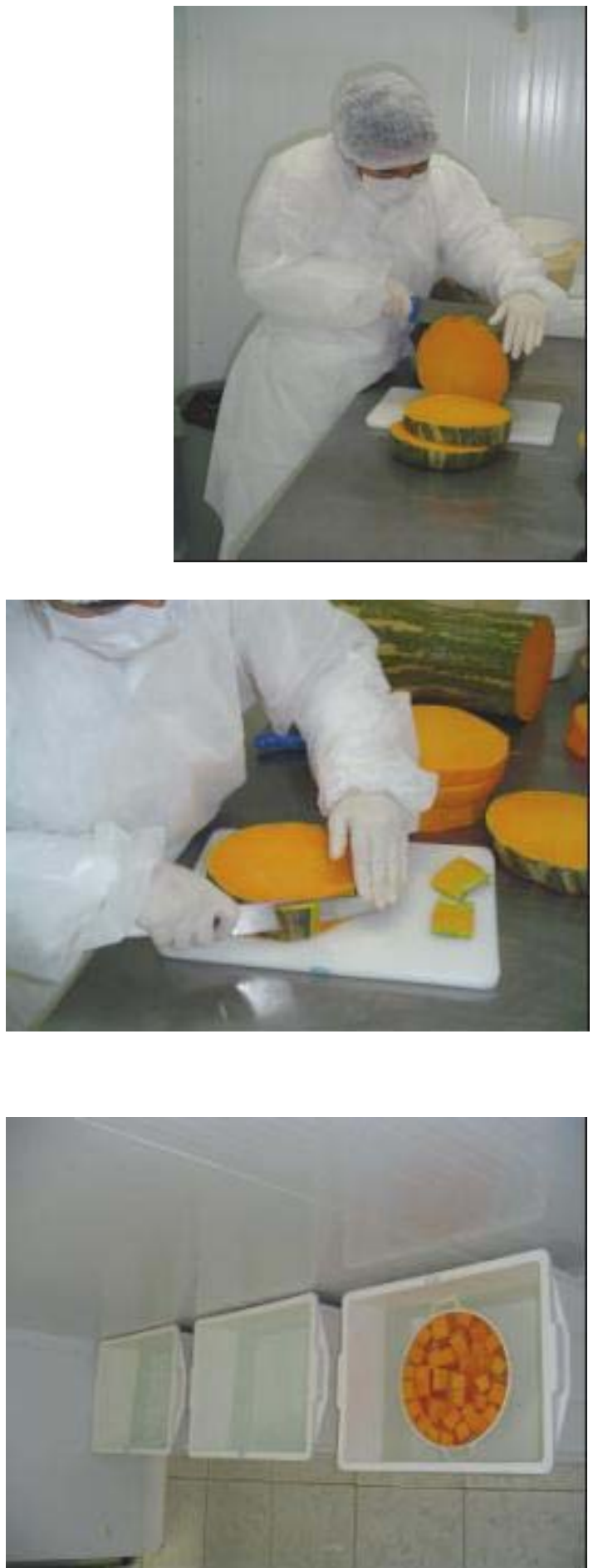

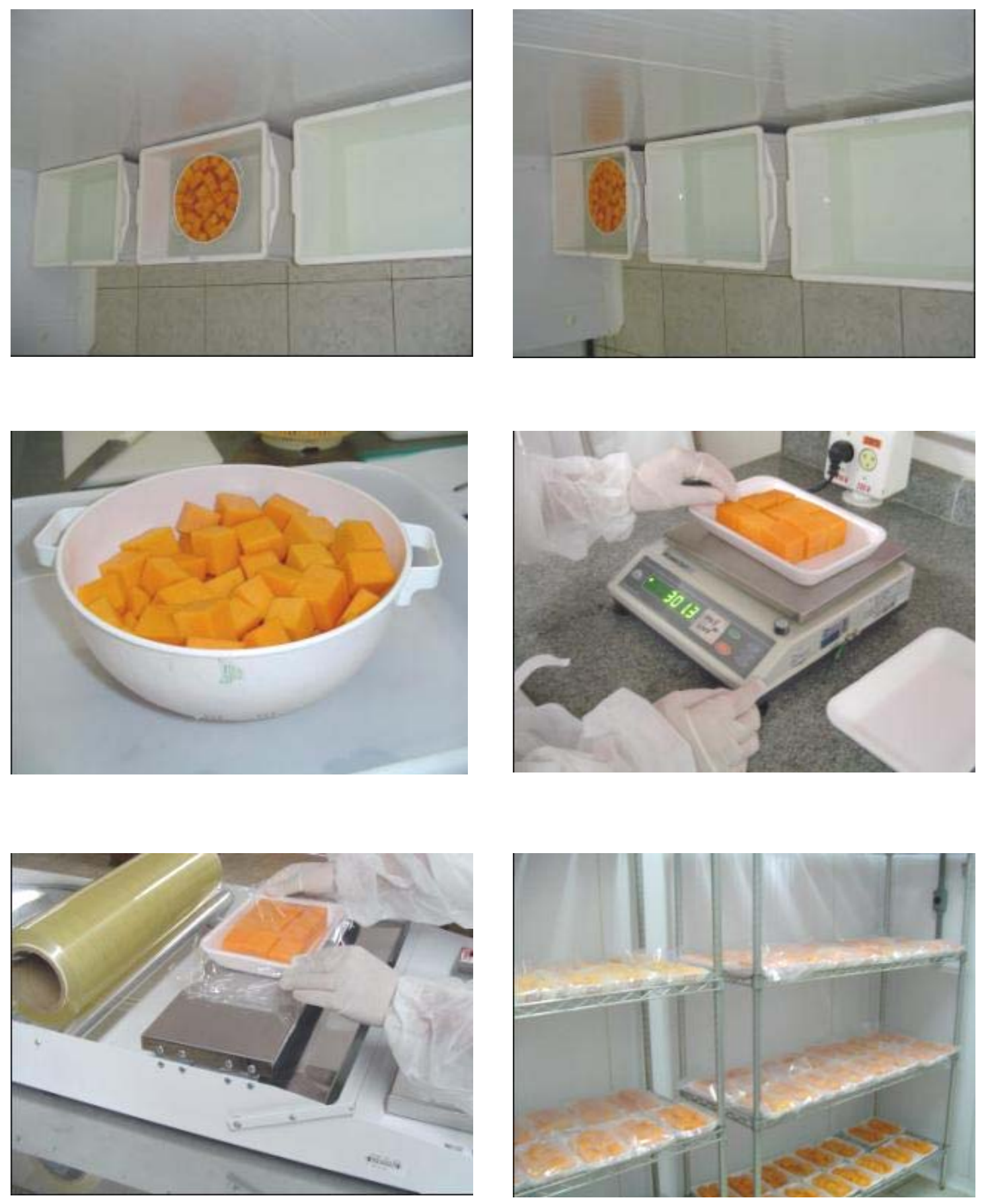
ANEXO B - Procedimentos para contagem de bactérias psicrotróficas.

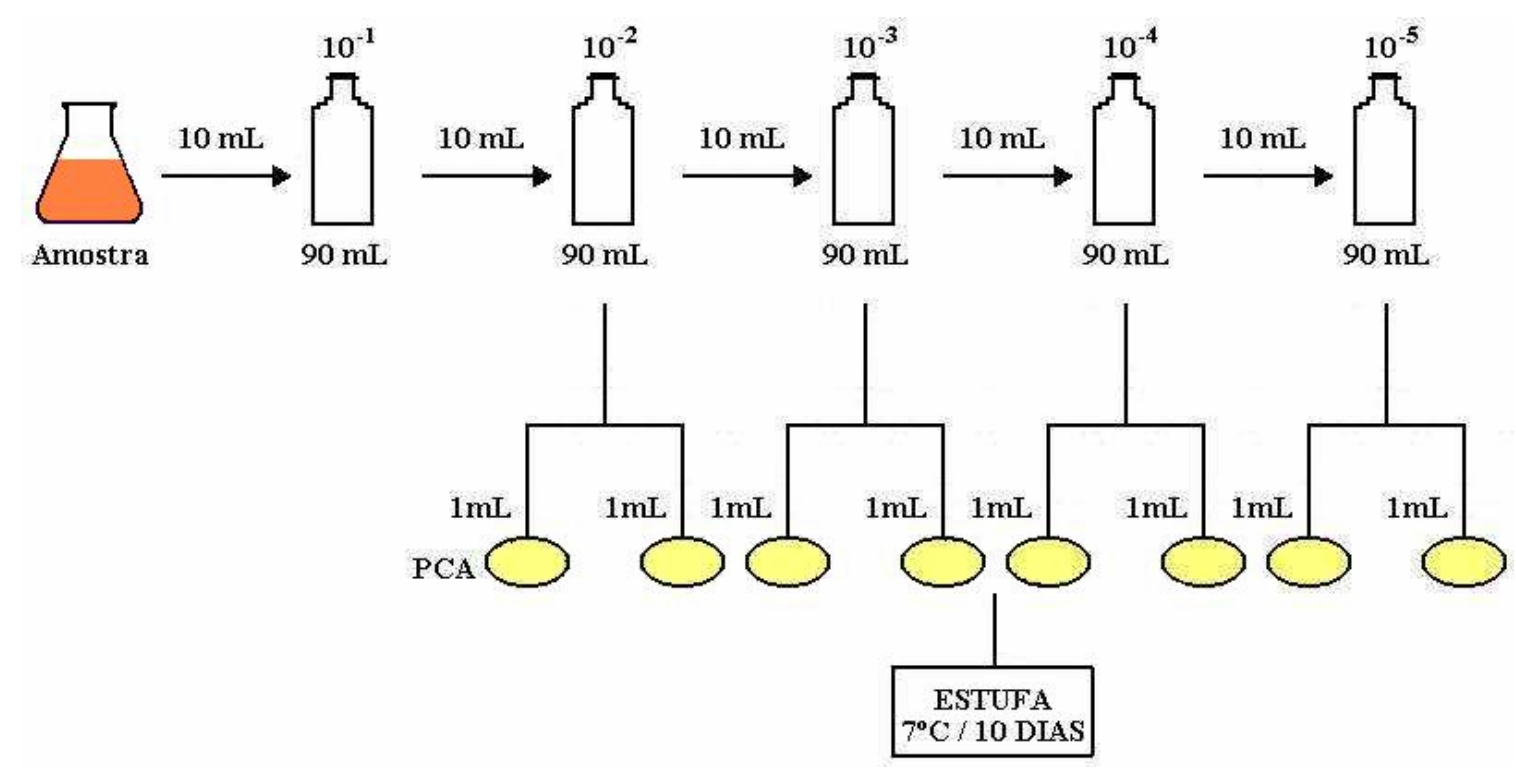

ANEXO C - Procedimento para contagem de coliformes totais e fecais.

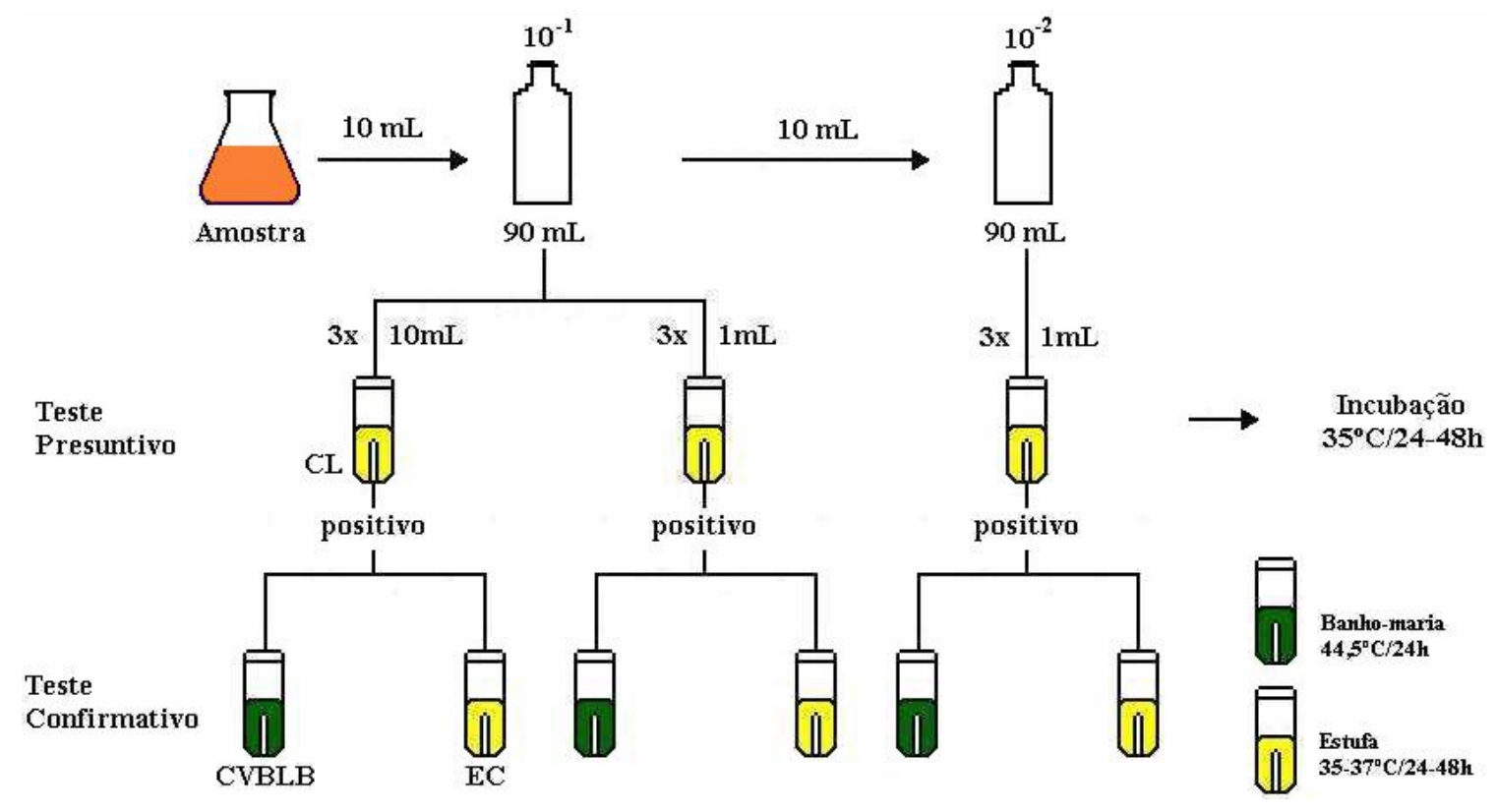




\section{REFERÊNCIAS BIBLIOGRAFICAS}

AGÊNCIA NACIONAL DE VIGILÂNCIA SANITÁRIA. Resolução - RDC $\mathbf{n}^{0} \mathbf{1 2}$, de 2 de janeiro de 2001. www.anvisa.gov.br/legis/resol/12 01rdc.htm (21 fev. 2002).

ABE, K.; WATADA, A.E. Ethylene absorbent to maintain quality of lightly processed fruits and vegetables. Journal of Food Science, v.56, n.6, p.1493-1496,1991.

ABELES, F.B.; MORGAN, P.W.; SALTVEIT JUNIOR, M.E. Ethylene in plant biology. 2ed. San Diego, California: Academic Press, 1992. 414p.

AHVENAINEN, R. New approaches in improving the shelf life of minimally processed fruit and vegetables. Trends in Food Science \& Technology, v.7, p.179-186, 1996.

ANUÁRIO DE INFORMAÇÕES ESTATÍSTICAS DA AGRICULTURA: Anuário IEA, 2000. São Paulo: IEA, 2001. 245p. (Serie de informação estatística na agricutlura, n. 1/01).

ARRUDA, M.C.; JACOMINO, A.P.; KLUGE, R.A.; AZZOLINI, M. Temperatura de armazenamento e tipo de corte para melão minimamente processado. Revista Brasileira de Fruticultura, v.25, n. 1, p. 74-76, 2003 a.

ARRUDA, M.C.; JACOMINO, A.P.; SARANTÓPOULOS, C.I.G.L.; MORETTI, C.L. Qualidade de melão minimamente processado armazenado em atmosfera modificada passiva. Horticultura Brasileira, v.21, n.4, p.655-659, out-dez. 2003b. 
ARTÉS, F.; MARTÍNEZ, J.A. Quality of cauliflower as influenced by film wrapping during shipment. European Food Research and Technology, v.209, n.5, p. 330-334, 1999.

AVENA-BUSTILLOS, R.J.; CISNEROS-ZEVALLOS, L.A.; KROCHTA, J.M.; SALTVEIT, M.E. Junior. Application of casein-lipid edible film emulsions to reduce white blush on minimally processed carrots. Postharvest Biology and Technology, v.4, n.4, p.319-329, 1994.

BARTH, M.M.; KERBEL, E.L.; BRORSSARD, S.; SCHMIDT, S.J. Modified atmosphere packaging protects market quality in broccoli spears under ambient temperatue storage. Journal of Food Science, v.58, p.1070-1072, 1993.

BARTH, M.M.; ZHUANG, H. Packaging design affects antoxidant vitamin retention and quality of broccoli florets during postharvest storage. Postharvest Biology and Technology, v.9, p.141-150, 1996.

BEN-YEHOSHUA, S. Individual seal-packing of fresh fruit and vegetables in plastic film - a new postharvest technique. HortScience, v.30, n.1, p. 35-38, 1985.

BENNETT, A.H. Principles and equipament for precooling fruits and vegetables. ASHRAE Symposium Bulletin. SF-4.70, U.S. Departament or Agriculture, 1971. 1v.

BETT, K.L.; INGRAM, D.A.; GRIMM, C.C.; LLOYD, S.W.; SPANIER, A.M.; MILLER, J.M.; GROSS, K.C.; BALDWIN, E.A.; VINYARD, B.T. Flavor of fresh-cut gala apples in barrier film packagig as affected by storage time. Journal of Food Quality, v.24, p.141-156, 2001.

BEUCHAT, L.C.; GOLDEN, D.A. Antimicrobials occurring naturally in foods. Food Technology, v.13, n.1, p.134-142, 1989.

BLANC, B. Biosynthèse dês vitamines liposolubles. 1973. 152p. Monographies de physiologie végétale. 
BOLIN, H.R.; HUXSOLL, C.C. Control of minimally processed carrot (Daucus carota) surface discoloration caused by abrasion peeling. Jounal of Food Science, v.56, n.2, p.416-418, 1991.

BRACKETT, R.E. Microbiological consequences of minimally processed fruits and vegetables. Journal of Food Quality. v.10, p.195-206, 1987.

BRACKETT, R.E. Shelf stability and safety of fresh cut produce as influenced by sanitation and desinfection. Journal os Food Protection, v.55, p.808-814, 1992.

BRACKETT, R.E. Alteración microbiológicas y microorganismos patógenos de frutas y hortaliças refrigeradas minimamente processadas. In: WILEY, R. C. Frutas y hortaliças minimamente processadas y refrigeradas. Zaragoza: Acribia, p. 263-304, 1997.

BRECHT, J.K. Physiology of ligthy processed fruits and vegetables. Hortscience, v. 30, n.1, p. 14, 1995.

BURNS, J.K. Lightly processed fruits and vegetables: Introduction to the colloquium. Hortscience, v. 30, n.1, p. 188-202, 1995.

CAMARGO FILHO, W. P. de; MAZZEI, A.R. O mercado de abóboras e morangas em São Paulo. Informações Econômicas, v. 32, n. 5, p. 69-72, mai 2002.

CAMARGO FILHO, W. P. de; MAZZEI, A.R.; ALVES, H.S. Mercado de abóboras nas cidades de São Paulo e Buenos Aires: oportunidades de expansão. Informações Econômicas, v. 33, n. 9, p. 61-65, set. 2003.

CANTWELL, M. Postharvest handling systems: minimally processed fruits and vegetables. In: KADER, A.A. (Ed.). Postharvest technology of horticultural crops. 2.ed. Davis: University of California, Dir. Agric. Nat. Res., 1992. p.277-281 (Publication, 3311).

CANTWELL, M. Preparation and quality of fresh produce. In: ENCONTRO NACIONAL SOBRE PROCESSAMENTO MÍNIMO DE FRUTAS E HORTALIÇAS, 2., Viçosa 2000. Palestras. Viçosa, UFV, 2000. p. 150-172. 
CARLLISTER, S.M.; AGGER, W.A. Enumeration and characterization oh Aeromonas hydrophilaahd Aeromonas caviae isolated from grocery store produce. Applied and Environmental Microbiology, v. 53, n. 2, p. 249253, feb. 1987.

CARUSO, J.G.B; CAMARGO, R. Microbiologia de alimentos. In: CAMARGO, R. (Ed.). Tecnologia dos produtos agropecuários-alimentos. São Paulo: Nobel, 1984. p.35-49.

CARVALHO, A.V.; LIMA, L.C.O. Avaliação da qualidade de kiwis minimamente processados submetidos ao tratamento com ácido ascórbico, ácido cítrico e cloreto de cálcio. In: ENCONTRO NACIONAL SOBRE PROCESSAMENTO MÍNIMO DE FRUTAS E HORTALIÇAS, 2., Viçosa 2000. Palestras. Viçosa: UFV, 2000. p. 10.

CARVALHO, C.R.L; MANTOVANI, D.M.B.; CARVALHO, P.R.N; MORAES, R M. Análises Químicas, Campinas: s. ed., 1990. 121p. (Manual Técnico)

CASALI, V.W.D.; SATURNINO, H.M.; PEDROSA, J.F. Botânica e origem das cucurbitáceas. Informe Agropecuário, v. 8, n. 85, p. 22-23, jan. 1982.

CHERRY, J.P. Improving the safety of fresh produce with antimicrobials. Food Technology, v.53, p.54-59, 1999.

CHITARRA, M.I.F. Processamento mínimo de frutos e hortaliças. Viçosa: Centro de Produções Técnicas, 1998. 88p.

CHITARRA, M.I.F.; CHITARRA, A.B. Pós-colheita de frutos e hortaliças. Lavras: ESAL; FAEFE, 1990. 320p.

CHITARRA, A.B.; ALVES, R.E. Tecnologia de pós-colheita para frutas tropicais. Fortaleza: FRUTAL-SINDIFRUTA, 2001. 1v.

CISNEROS-ZEVALLOS, L.; SALVEIT, M.E.; KROCHTA, J.M. Mechanism of surface white discoloration of peeled (minimally processed) carrots during storage. Jounal of Food Science, v.60, n.2, p. 320-323, 1995. 
DANIELS, J.A.; KRISHNAMURTHI, R.; RIZVI, S.S.H. A review of effects of carbon dioxide on microbial grow and food quality. Journal of Food Protection, v. 48, n. 6, p. 532-537, 1985.

DONG, X.; WROLSTAND, R.E.; SUGAR, D. Extending shelf lifeof fresh-cut pears. Journal of Food Science, v.65, p.181-186, 2000.

DYCHDALA, G.R. Chlorine and chlorine compounds. In: SEYMOUR, S.B. Desinfection sterilization and preservation. 4 ed., s.I., p. 131-151, 1991.

DURIGAN, J.F.; SARGENTE, S.A. Uso de melão Cantaloupe na produção de produtos minimamente processados. Alimentos e Nutrição, v.10, p.69-77, 1999.

DURIGAN, J.F.; CASSARO, K.P. Hortaliças minimamente processadas. Hoticultura Brasileira, v.18, p.159-161, jul. 2000.

ELLIOTT, J.G. Application of antioxidant vitamins in foods and beverages. Food Technology, v.53, n.2, p.46-48, 1999.

FANTUZZI, E. Atividade microbiana em repolhos (Brassica oleraceae cv. capitata) minimamente processada, Viçosa. 1999, 50p. Dissertação (Mestrado)-Universidade Federal de Viçosa.

FILGUEIRA, F.A.R. Novo manual de olericultura: agrotecnologia moderna na produção e comercialização de hortaliças. Viçosa. 2000. 402p.

FINGER, F.L.; VIEIRA, G. Controle da perda pós-colheita de água em produtos minimamente processados. Viçosa: UFV, 1997. 29p.

FRANCO, G. Tabela de composição química dos alimentos, 9. ed., s.I., s. ed., 1998. 307p.

FRUTIFATOS A importância dos pré-processados. Informação para a fruticultura irrigada. Brasília: Ministério da Integração Nacional/Secretaria de Infra-Estrutura Hídrica, v.1, n.1, p.16-18, 1999. 
GARCÍA-GIMENO, R.M., ZURERA-COSANO, G. Determination of ready-to-eat vegetable salad shelf-life. Internation Journal of Food Microbiology, v.36, p.31-38, 1997.

GAVA, A.J. Princípios de tecnologia de alimentos. São Paulo: Nobel, 1984, $284 p$.

GIL, M.I.; CONESA, M.A.; ARTÉS, F. Quality changes in fresh cut tomato as affected by modified atmosphere packaging. Postharvest Biology and Technology, v.25, n.2, p. 199-207, Jun, 2002.

GONZÁLEZ-AGUILAR, G.A.; AYALA-ZAVALA, J.F., RUIZ-CRUZ, S.; ACEDOFÉLIX E.; DÍAZ-CINCO, M.E. Effect of temperature and atmosphere packaging on overall quality of fresh-cutbell peppers. Lebensm-Wiss.u.Technology, v.37, p. 817-826, 2004.

GORNY, J.R.; CIFUENTES, R.A.; HESS-PIERCE, B.H.; KADER, A.A. Quality changes in fresh-cut pear slices as affected by cultivar, ripeness stage, fruit size and storage regime. Journal of Food Science, v. 65, p.541-544, 2000.

HABIBUNNISA, R., BASKARAN, RAJENDRA PRASAD, KRISHNAPRAKASH MYSORE SHIVAIAH, HABIBUNNISA Storage behavior of minimally processed pumpkin (Cucurbita maxima) under modified atmosphere packaging conditions. European Food Research and Technology, v. 212, n. 2, p. 165-169, 2001.

HARDENBURG, R.E.; WATADA, A.E.; WANG, C.Y. The commercial storage of fruits, vegetables, and florist, and nursery stoks. Washington: USDA, 1986. 130p. (USDA Agriculture Handbook, 66).

HILGREN, J.D.; SALVERDA, J.A. Antimicrobial efficacy of a peroxyacetic/octanoic acid mixture in fresh-cut vegetable process waters. Journal of Food Science, v.65, p.1376-1379, 2000.

HINTLIAN, C.B.; HOTCHKISS, J.H. The safety of modified atmosphere packaging: a review. Food Technology, v. 40, n. 12, p. 70-76, 1986. 
HIRAISHI, A.; HORIE, S. Species composition and growth temperature characteristics of coliforms in relation to their sources. Journal of General Applied Microbiology, v. 28, n.1, p. 139-154, 1982.

HONG, S.; KIM, D. Influence of oxygen concentration and temperature on respiratory characteristics of fresh-cut green onion. International Journal of Food Science and Technology, v.36, n.3, p.283-289, mar. 2001.

HOTCHKISS, J.H. Safety considerations in active packaging. In: ROONEY, M.L. Active food packaging. Glasgrow: Chapman \& Hall, 1995. p. 238-255.

HURST, W.C. Disinfection methods: A comparison of chlorine dioxide, ozone and ultraviolet light alternatives. Cutting Edge Produce Association, v.9, p.4-5, 1995.

HUXSOLL, C.C.; BOLIN, H.R. Processing and distribuition alternatives for minimally processed fruits and vegetables. Food Technology, v.43, n.2, p.124-128, 1989.

INTERNACIONAL COMMISSION ON MICROBIOLOGICAL SPECIFICATIONS FOR FOODS. Microorganisms in foods. 2 ed. Toronto: University of Toronto Press, 1978. v. 1, 434p.

INTERNACIONAL FRESH CUT PRODUCT ASSOCIATION. Fresh-cut produce handling guidelines. 3.ed. Newark: Produce Marketing Association, 1999. 39p.

IZUMI, H.; WATADA, A.E Calcium treatments affect storage quality of shredded carrots. Journal of Food Science, v.59, n.1, p.106-109, 1994.

IZUMI, H.; WATADA, A.E.; KO, N.P.; DOUGLAS, W. Controlled atmosphere storage of carrots slices, sticks and shreds. Postharvest Biology and Technology. v.9, n.2, p. 165-172, 1996. 
JACOMINO, A.P.; ARRUDA, M.C. Aplicações da atmosfera modificada em produtos minimamente processados. In: ENCONTRO NOCIONAL SOBRE PROCESSAMENTO MÍNIMO DE FRUTAS E HORTALIÇAS, 3, Viçosa 2004. Palestras, Resumos e Oficinas. Viçosa: UFV, 2004. p. 48-52.

KADER, A.A. Biochemical and physiolosical basis for effects of controlled and modified atmospheres on fruits and vegetables. Food Technology, v.40, n.5, p. 99-104, 1986.

KADER, A.A. Postharvest tecnology of horticultural crops. Davis: California. Division of Agriculture and Natural Resources- University of California, 1992. $296 p$.

KAYS, J.S. Postharvest physiology of perishable plants products. New York: Van Nostrand Reinhold, 1991. 532p.

KING JUNIOR, A.D.; BOLIN, H.R. Physiological and microbiological storage stability of minimally processed fruits and vegetables. Food Technology. v.43, n.2, p.132-135, 1989.

KLEIN, B.P. Nutricional consequences of minimal processing of fruits and vegetables. Journal of Food Quality, v.10, p. 179-193, 1987.

KLEIN, B.P.; KING, D.; GROSSMAN, S. Cooxidation reations of lipoxygenase in plant systems. Advances Free Radical Biology and Medicine, v.1, p.309343, 1985.

KLUGE, R.A.; NACHTIGAL, J.C; FACHINELLO, J.C.; BILHALVA, A.B. Fisiologia e manejo pós-colheita de frutas de clima temperado. 2. ed., S.I.: Rural, 2002. 214p.

LANA, M.M Aspectos da fisiologia de cenoura minimamente processada. Horticultura Brasileira, v.18, n.3, p.154-158, nov. 2000.

LANA, M.M.; FINGER, F.L. Atmosfera modificada e controlada: Aplicação na conservação de produtos hortícolas. Brasília: Embrapa Comunicação para Transferência de Tecnologia/Embrapa Hortaliças, 2000. 34p. 
LEE, K.S.; KADER, A.A. Preharvest and postharvest factors influencing vitamin C content of horticultural crops. Postharvest Biology and Technology, v.20, p.207-220, 2000.

LILLY JUNIOR, T.; SOLOMON, H.M.; RHODEHAMEL, E.J. Incidence os Clostridium botulinum in vegetables packaged under vacum or modified atmosphere. Journal os Food Protection, v. 59, n.1, p. 59-61, 1996.

LUENGO, R.F.A.; LANA, M.M. Processamento mínimo de hortaliças. Brasília: EMBRAPA Hortaliças, 1997. 3p. (Comunicado Técnico, 2).

LUENGO, R.de F.A. et al. Tabela de composição nutricional das hortaliças, Brasília: EMBRAPA Hortaliças, 2000. 4p. (Embrapa Hortaliças. Documentos, 26).

MERTENS, H.; TRANGGONO, Ethylene and repiratory metabolism of cauliflower (Brassica oleracea L. convar. Botrytis) in controlled atmosphere storage. Acta Horticulturae, v.258, p.493-501, 1989.

MORETTI, C.L. Processamento mínimo de hortaliças: alternativa viável para a redução de perdas pós-colheita e agregação de valor ao agronegócio brasileiro. Horticultura Brasileira, v.17, n.2, p.1, 1999.

MORETTI, C.L. Panorama do processamento mínimo de hortaliças. In: ENCONTRO NOCIONAL SOBRE PROCESSAMENTO MÍNIMO DE FRUTAS E HORTALIÇAS, 3.; Viçosa 2004. Palestras, Resumos e Oficinas. Viçosa, UFV, 2004. p. 1-8.

MORETTI, C.L.; MAROUELLI, W.A.; SILVA, W.L.C. Respiratory activity and browning of minimally processed sweet potatoes. Horticultura Brasileira, v.20, p.497-500, 2002.

MORTON, R.D. Aerobic plate count. In: DOWNES, F.P.; ITO, K. Compendium of methods for the microbiological examinations of foods. 4.ed. Washington: American Public Health Association, 2001. p.63-67. 
MIRANDA, R.B. Avaliação da qualidade do mamão (Carica papaya L.) minimamente processado, Lavras, 2001. 71p. Dissertação (Mestrado)Universidade Federal de Lavras.

MOZAFAR, A. Plant Vitamins: Agronomic, Physiological and Nutricional Aspects. CRC Press, Boca Raton; FL: 1v, 1994. 1v.

NGUYEN, C.; CARLIN, F. The microbiology of minimaly processed fresh fruits and vegetables. Critical Reviews in Food Science and Nutrition, v. 34, n.4, p. 371-401, 1994.

OLIVEIRA, E.C.M. Influência da sanitizantes na qualidade de mamão de safra e entressafra minimamente processado, Lavras, 2001. 88p. Dissertação (Mestrado)-Universidade Federal de Lavras.

OLIVERIA, E.C.M.; VALLE, R.H.P. do Aspectos microbiológicos dos produtos hortícolas minimamente processados. Higiene Alimentar, v.11, n.78/79, nov./dez. 2000.

PALMER-WRIGHT, K.; KADER, A.A. Effect os controlled-atmosphere storage on the quality ond carotenoid content of sliced persimmons and peaches. Postharvest Biology and Technology, v.10, p.89-97, 19997.

PIAGENTINI, A.M.; PIROVANI, M.E.; GUEMES, D.R. et al. Survival and growth of Salmonella hadar on minimally processed cabbage as influencied by storage abuse condition. Journal of Food Science, v.62, n.3, p.616-618, 1997.

PINTO, S.A.A. Processamento mínimo de melão tipo Orange Fresh e de melancia 'Crimson Sweet'. Jaboticabal, 2002. 120p. Dissertação (Mestrado)Universidade Estadual Paulista “Julio de Mesquita Filho".

PORTE, A.; MAIA, L.H. Alterações fisiológicas, bioquímicas e microbiológicas de alimentos minimamente processados. Boletim do CEPPA, v.19, n.1, p.105-118, jan./jun. 2001. 
PURVIS, A.C. The role adaptive anzymes in carbohydrates oxidation by stressed and senescing plant tissues. HortScience, v.32, n.7, p.1165-1168, 1997.

PUSHMANN, R.; SILVA, E. de O., CARNELOSSI, M.A.G; TELES, C.S. Processamento mínimo de hortaliças.Viçosa: s. ed., jan. 2002. 5p.

RODRIGUEZ-AMAYA, D.B. Caracterização de carotenóides e avaliação do valor da vitamina A. Produção Científica, v.1, 1985. 56p.

RODRIGUEZ-AMAYA, D.B. A guide to carotenoid analysis in foods. Washington: International Life Sciences Institute (ILSI), 2001, 63p.

RODRIGUEZ-AMAYA, D.B. Brazil: A bounty of carotenoid sources. Sight and Life, Newsletter, v.1, n.4, p. 3-9, abr. 2002.

RODRIGUEZ-AMAYA, D.B.; AMAYA-FARFÁN, J. Estado actual de los métodos analíticos para determinar provitamina A. Archivos Latinoamericanos de Nutricion, v.42, n.2, p.180-191, 1992.

RODRIGUEZ-AMAYA, D.B.; KIMURA, M. HarvestPlus handbook for carotenoid analysis. Washington DC: International Food Policy Research Institute (IFPRI). 2004, 1v. (HarvestPlus technical monography series 2).

ROLLE, R; CHISM, G.W. Phisilogical consequences of minimally processed fruits and vegetables. Journal of Food Quality, v.10, p.157-165, 1987.

ROSA, O.O.; CARVALHO, E.P.de Características microbiológicas de frutas e hortaliças minimamente processadas. Boletim da Sociedade Brasileira de Ciência e Tecnologia de Alimentos (SBCTA), v. 34, n. 2, p. 84-92, jul./dez. 2000.

SAKR, S.; NOUBAHNI, M.; BOURBOULOUX, A. Cutting, ageing and expression of plant membrane transporters. Biochimica et Biophysica Acta, v.1330, p.207-216, 1997. 
SARZI, B. Conservação de abacaxi e mamão minimamente processados: associação entre $\mathrm{o}$ preparo, a embalagem e a temperatura de armazenamento. Jaboticabal, 2002. 100p. Dissertação (Mestrado)Universidade Estadual Paulista "Julio de Mesquita Filho".

SCHLIMME, D.V. Marketing lightly processed fruits and vegetables. HortScience, v. 30, n.1, p. 15-17, feb., 1995.

SCHLIMME, D.V.; ROONEY, M.L. Envasado de frutas y hortaliças mínimamente procesadas. In: WILEY, R.C. Frutas y hortaliças minimamente processadas y refrigeradas. Zaragoza: Acribia, p. 131-177, 1997.

SIGRIST, J.M.M. Tecnologia pós-colheita de frutas e hortaliças tropicais. Campinas: ITAL-Instituto de Tecnologia de Alimentos, 1988. 199p. (Manual Técnico, 9).

SIGRIST, J.M.M. Hortaliças Minimamente Processadas e Fatores que Afetam sua Qualidade. In: CONGRESSO BRASILEIRO DE OLERICULTURA, 38, Petrolina, 1998. Anais Petrolina: SOB, 1998.

SIGRIST, J.M.M. Estudos fisiológicos e tecnológicos de couve-flor e rúcula minimamente processadas. Piracicaba, 2002. 112p. Tese (Doutorado)Escola Superior de Agricultura "Luiz de Queiroz", Universidade de São Paulo.

SPAGNOL, W.A. Processamento mínimo de cenoura e feijão-vagem. Campinas. 2005. 187p. Tese (Doutorado)-Universidade de Campinas.

SILVA, N. da; JUNQUEIRA, V.C.A.; SILVEIRA, N.F.A. Manual de métodos de análises microbiológicas de alimentos. São Paulo: Varela, 2001. 317p.

SMYTH, A.B.; SONG, J.; CAMERON, A.C. Modified atmosphere packaged cut Iceberg lettuce: effect of temperature and $\mathrm{CO} 2$ partial pressure on respiration and quality. Jounal of Agricultural and Food Chemistry, v.46, n.11, p.4556-4562, nov. 1998. 
SOLIVA-FORTUNY, R.C.; MARTIN-BELLOSO, O. New advances in extending the shelf-life of fresh-cut fruits: a review. Trends in Food Science \& Technology, v.14, p.341-353, 2003.

SOUZA, R.A.M. de Mercado para produtos minimamente processados. Informações Econômicas, v.31, n.3, p. 7-18, março 2001.

TAIZ, L.; ZEIGER, E. Fisiologia Vegetal , traduzido por Paulo Luiz Oliveira [et al.] , 3.ed. s.l.: ARTMED, 2004. p. 162-314.

TATSUMI, Y.; WATADA, A.E.; WERGIN, W.P. Scanning electron microscopy of carrot stick surface to determine cause of white translucent appearance. Journal os Food Science, v.56, p. 1357-1362, 1991.

TATSUMI, Y.; WATADA, A.E.; LING, P.P. Sodium chlorine treatment or waterjet slicing effects on white tissue development os carrot sticks. Journal of Food Science, v.58, n.6, p.1390-1392, 1993.

TELES, C.S. Avaliação física, química e sensorial de couve (Brassica oleracea, L. var. Acephala) minimamente processada, armazenada sob atmosfera modificada. Viçosa, 2001. Dissertação (Mestrado). Universidade Federal de Viçosa.

VANETTI, M.C.D. Controle microbiológico e higiene no processamento mínimo. In: ENCONTRO NACIONAL SOBRE PROCESSAMENTO MÍNIMO DE FRUTAS E HORTALIÇAS, 2., Viçosa, 2000. Palestras. Viçosa: UFV, 2000. p.44-52.

VAROQUAUX, P.; WILEY, R.C. Cambios biológicos y bioquímicos en frutas y hortaliças refrigeradas minimamente processadas. In: WILEY,R.C. Frutas y hortaliças minimamente processadas y refrigeradas. Zaragoza: Acribia, 1997. p. 221-262.

VERLINDEN, B.E.; NICOLAI, B.M. Fresh-cut fruits and vegetables. Acta Horticulturae, v. 518, p. 223-231, 2000. 
VITTI, M.C.D. Aspectos fisiológicos, bioquímicos e microbiológicos em beterrabas minimamente processadas, Piracicaba: ESALQ. 2003. 116p. Dissertação (Mestrado)- Escola Superior de Agricultura "Luiz de Queiroz", Universidade de São Paulo.

VITTI, M.C.D; KLUGE, R.A. Prontos para o consumo. Revista Frutas e Legumes, n.15, p. 22-28, ago./set., 2002a.

VITTI, M.C.D; KLUGE, R.A. Prontos para o consumo: Produtos minimamente processados. In: SEMINÁRIO DE FLORES, FRUTAS E HORTALIÇAS: PANORAMA DA PÓS-COLHEITA E COMERCIALIZAÇÃO. Piracicaba, 2002. Anais. Piracicaba: ESALQ, 2002b. 1v.

WATADA, A.E. Effects of ethylene on the quality of fruits and vegetables. Food Technology, v.44, n.5, p. 82-85, 1986.

WATADA, A.E.; ABE, K.; YAMUCHI, N. Physiological activities of partially processed fruits and vegetables. Food Technology, v.44, n.5, p. 116-112, 1990.

WATADA, A.E.; KO, N.P.; MINOTT, D.A. Factors affecting quality of fresh-cut horticultural products. Postharvest Biology and Technology, v.9, n.2, p.115-125, nov. 1996.

WEICHMANN, J. Low oxigen effects. In: POSTHARVEST physiology of vegetavles. New York: Marcel Dekker, 1987. p. 231-238.

WILEY, R.C. Frutas y hortalizas mínimamente procesadas y refrigeradas. Zaragoza: Acribia, 1997. 362p.

YAM, K.L.; LEE, D.S. Design of modified atmosphere packaging for fresh produce. In: ROONEY, M.L. Active food packaging. Glasgrow: Chapman \& Hall, 1995. p. 55-73.

YANG, S.F. Biosynthesis and action of ethylene. HortScience, v.20, n.1, p. 4145, 1985. 
ZHANG, S.; FARBER, J.M. The effects os various disinfectants against Listeria monocytogenes on fresh-cut vegetables. Food Microbiology, v.13, p.311321, 1996. 